University of South Florida

DIGITAL COMMONS

Digital Commons @ University of

@ UNIVERSITY OF SOUTH FLORIDA

South Florida

USF Accountability Reports

USF Archives

$1-1-2010$

\title{
2010 Annual Report USF System
}

USF

Follow this and additional works at: https://digitalcommons.usf.edu/usf_accountability_reports

\section{Scholar Commons Citation}

USF, "2010 Annual Report USF System" (2010). USF Accountability Reports. 9.

https://digitalcommons.usf.edu/usf_accountability_reports/9

This Article is brought to you for free and open access by the USF Archives at Digital Commons @ University of South Florida. It has been accepted for inclusion in USF Accountability Reports by an authorized administrator of Digital Commons @ University of South Florida. For more information, please contact digitalcommons@usf.edu. 


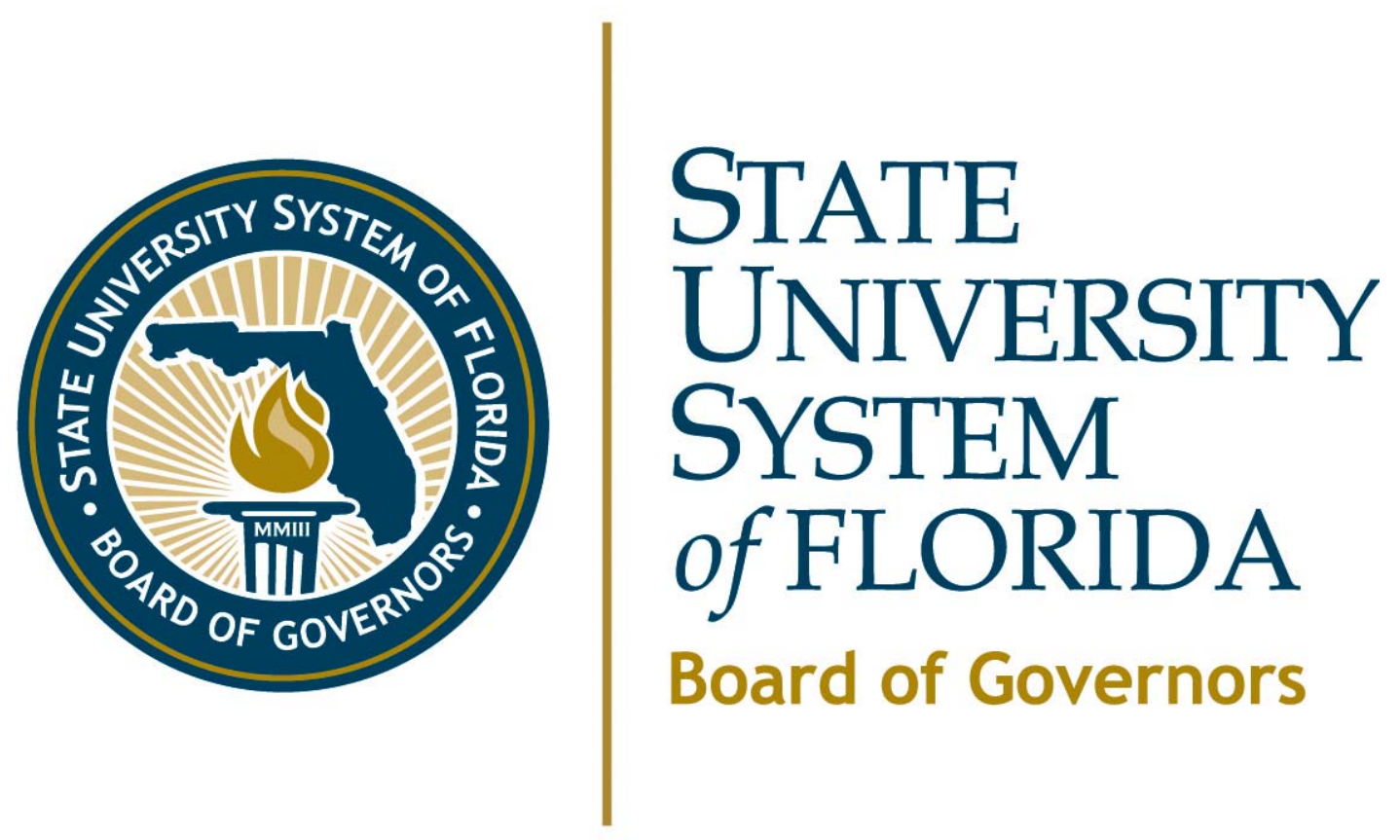

2010 Annual Report

Volume I 
This page is intentionally left blank. 


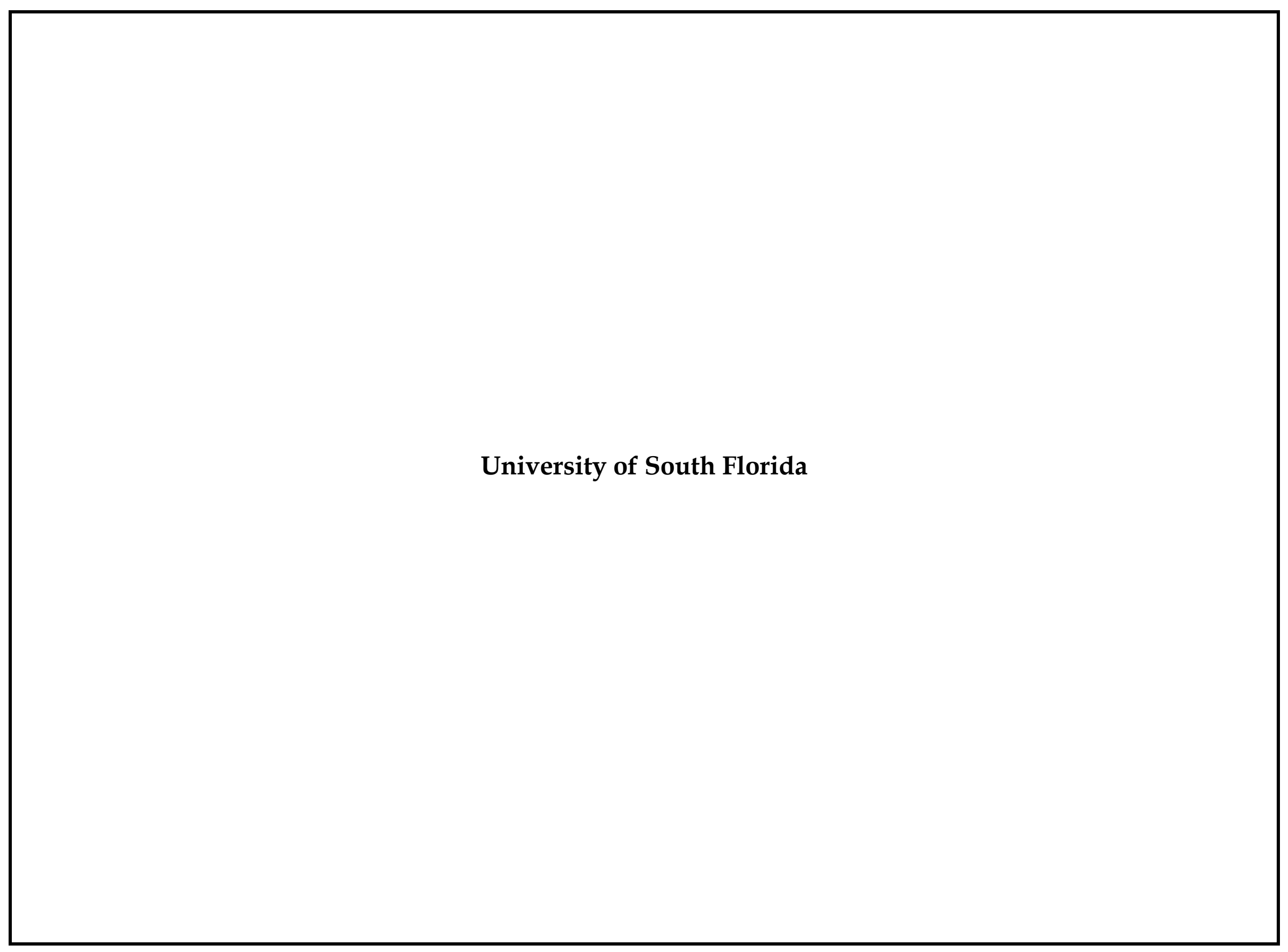


Data definitions are provided in the Appendices.

Note concerning data accuracy: The Office of the Board of Governors believes that the
accuracy of the data it collects and reports is paramount to ensuring accountability in the
State University System. Thus, the Board Office allows university resubmissions of some data
to correct errors when they are discovered. This policy can lead to changes in historical data. 


\begin{tabular}{|c|c|c|c|c|c|c|c|}
\hline \multicolumn{8}{|c|}{ University of South Florida 2010 Annual Report } \\
\hline \multicolumn{3}{|c|}{ Sites and Campuses } & \multicolumn{5}{|c|}{ USF Tampa Campus, USF St. Petersburg Campus, USF Sarasota-Manatee Campus, USF Polytechnic Campus } \\
\hline Enrollments & Headcount & $\%$ & \multicolumn{3}{|c|}{ Degree Programs Offered (As of Spr. 10) } & \multicolumn{2}{|c|}{ Carnegie Classification } \\
\hline $\begin{array}{l}\text { TOTAL } \\
\text { (Fall 2009) }\end{array}$ & 47,306 & $100 \%$ & \multicolumn{2}{|l|}{ TOTAL } & 233 & $\begin{array}{c}\text { Undergraduate } \\
\text { Instructional Program: }\end{array}$ & $\begin{array}{l}\text { Balanced arts \& sciences/professions, } \\
\text { high graduate coexistence }\end{array}$ \\
\hline Black & 5,284 & $11 \%$ & \multicolumn{2}{|c|}{ Baccalaureate } & 92 & Graduate Instructional & Comprehensive doctoral \\
\hline Hispanic & 6,242 & $13 \%$ & \multicolumn{2}{|c|}{ Master's \& Specialist's } & 100 & Program: & with medical/veterinary \\
\hline White & 30,520 & $65 \%$ & \multicolumn{2}{|c|}{ Research Doctorate } & 38 & Enrollment Profile: & High undergraduate \\
\hline Full-Time & 30,875 & $65 \%$ & \multirow{2}{*}{$\begin{array}{l}\text { Faculty } \\
\text { (Fall 2009) }\end{array}$} & \multirow{2}{*}{$\begin{array}{l}\text { Full- } \\
\text { Time }\end{array}$} & \multirow{2}{*}{ Part-Time } & Size and Setting: & Large four-year, primarily nonresidential \\
\hline Part-Time & 16,431 & $35 \%$ & & & & \multirow{2}{*}{ Basic: } & \multirow{2}{*}{$\begin{array}{c}\text { Research Universities } \\
\text { (very high research activity) }\end{array}$} \\
\hline Undergraduate & 35,834 & $76 \%$ & TOTAL & 1,618 & 320 & & \\
\hline Graduate & 9,273 & $20 \%$ & Tenure/T. Track & 1,115 & 79 & \multirow{2}{*}{ Elective Classification: } & Community Engagement: \\
\hline Unclassified & 2,199 & $5 \%$ & Other Faculty/Instr. & 503 & 241 & & Outreach \& Partnerships \\
\hline
\end{tabular}

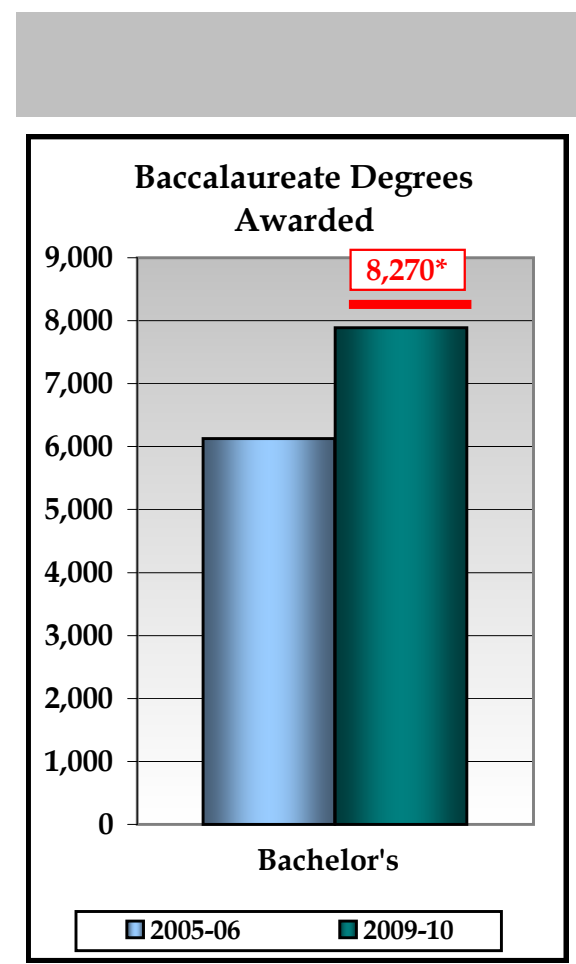

BOARD OF GOVERNORS - STATE UNIVERSITY SYSTEM GOAL 1:

ACCESS TO AND PRODUCTION OF DEGREES

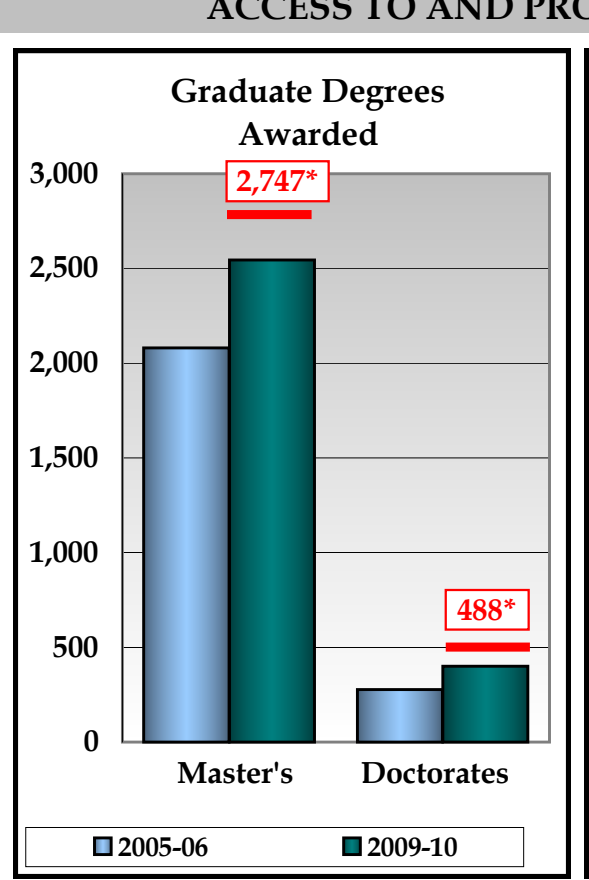

*2012-13 Targets for Degrees Awarded.

Note: All targets are based on 2010 University Workplans.
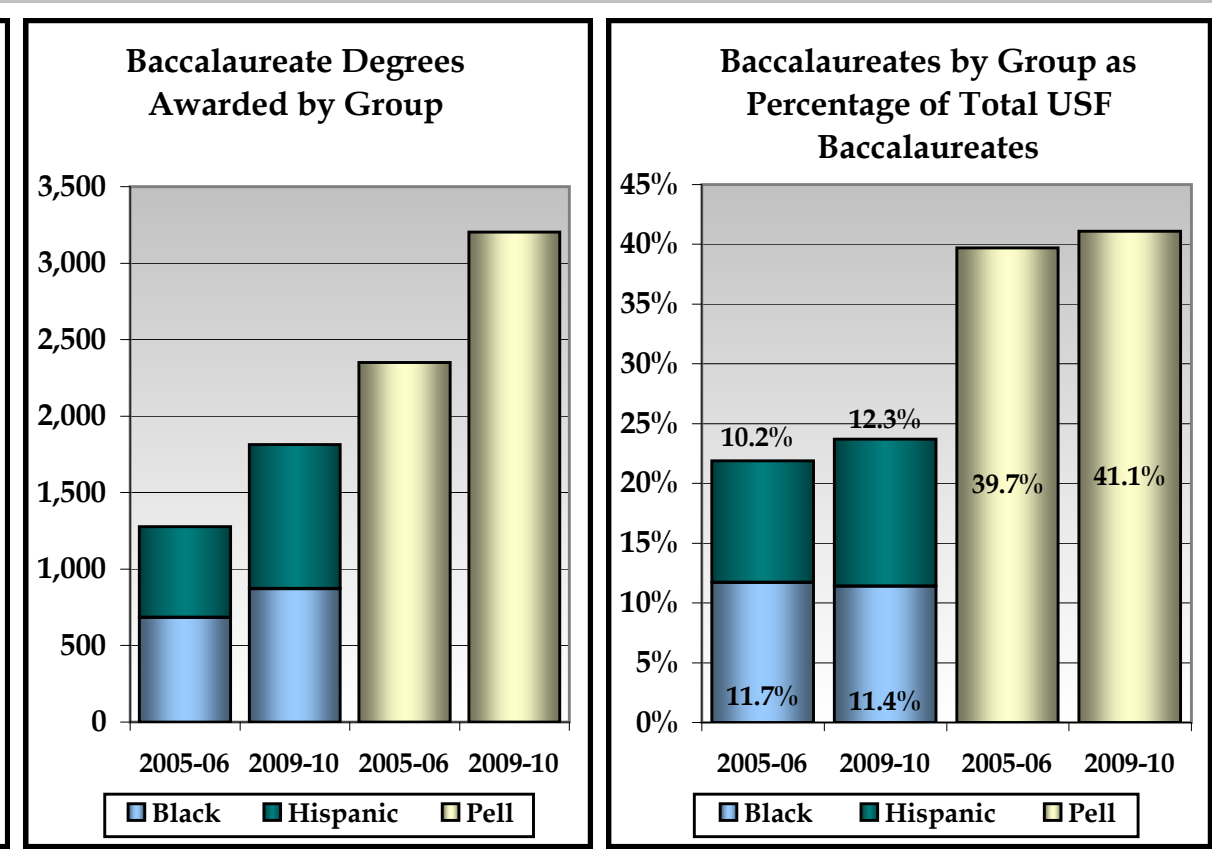

[2012-13 Targets for Baccalaureates By Group Reported in Volume II - Table 4I.].

University of South Florida - Page 3 
BOARD OF GOVERNORS - STATE UNIVERSITY SYSTEM GOAL 2:

MEETING STATEWIDE PROFESSIONAL AND WORKFORCE NEEDS

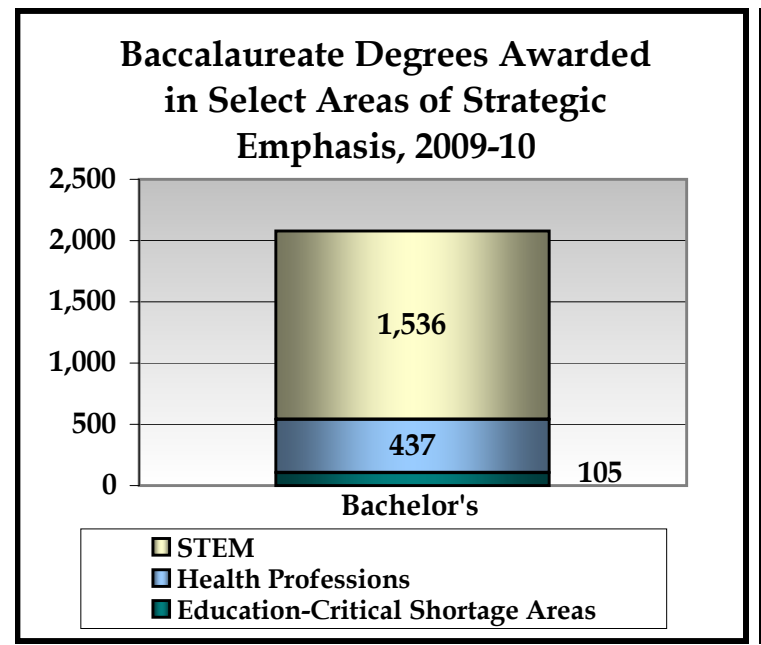

2012-13 Target: Increase (2008-09 Baseline: 1,942 Total)
Graduate Degrees Awarded in Select Areas of Strategic Emphasis, 2009-10

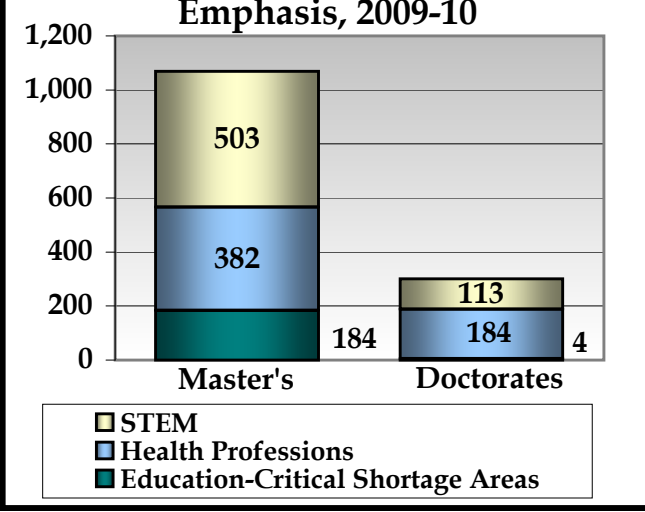

2012-13 Target: Increase (2008-09 Baseline: 1,258 Total)

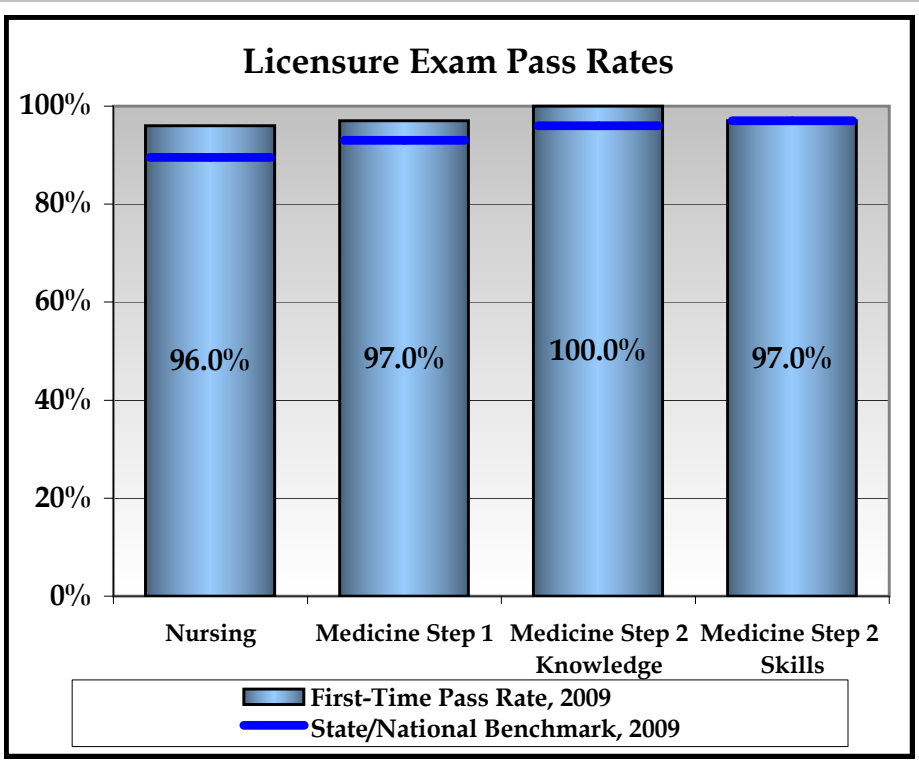

State/National Benchmark, 2009

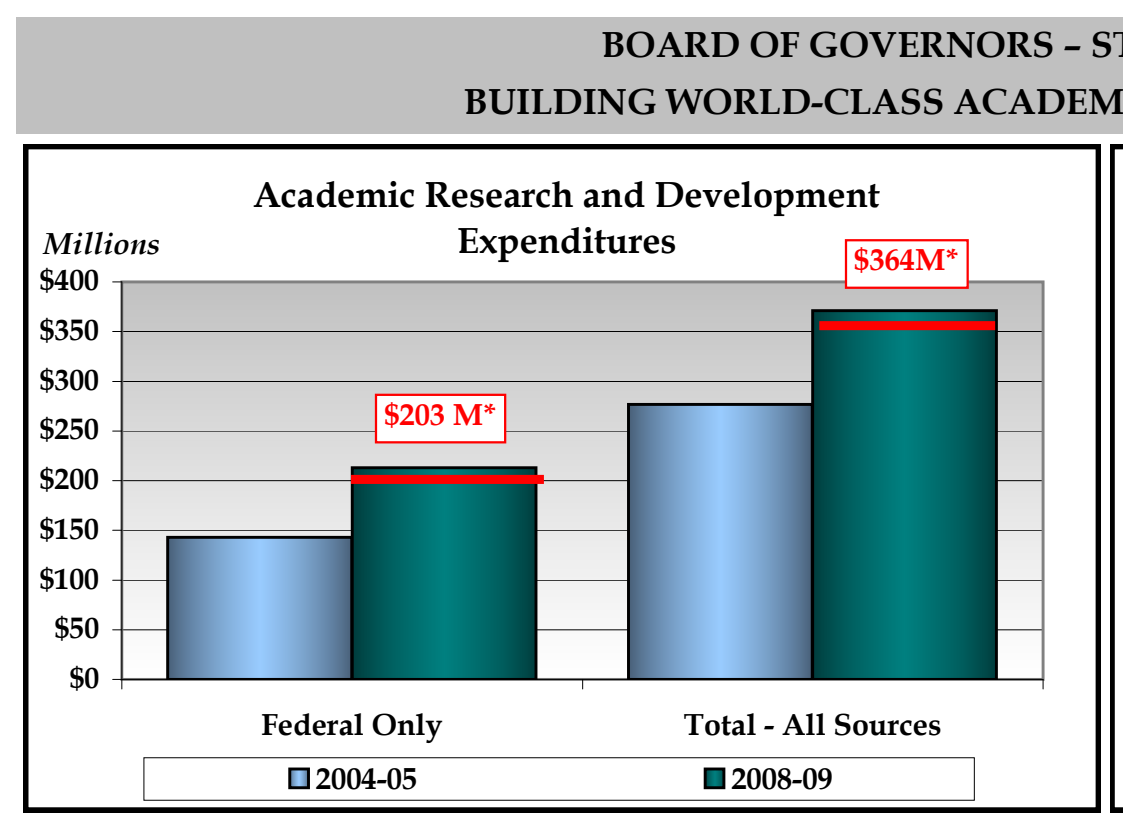

*2011-12 Targets for Research \& Development Expenditures.

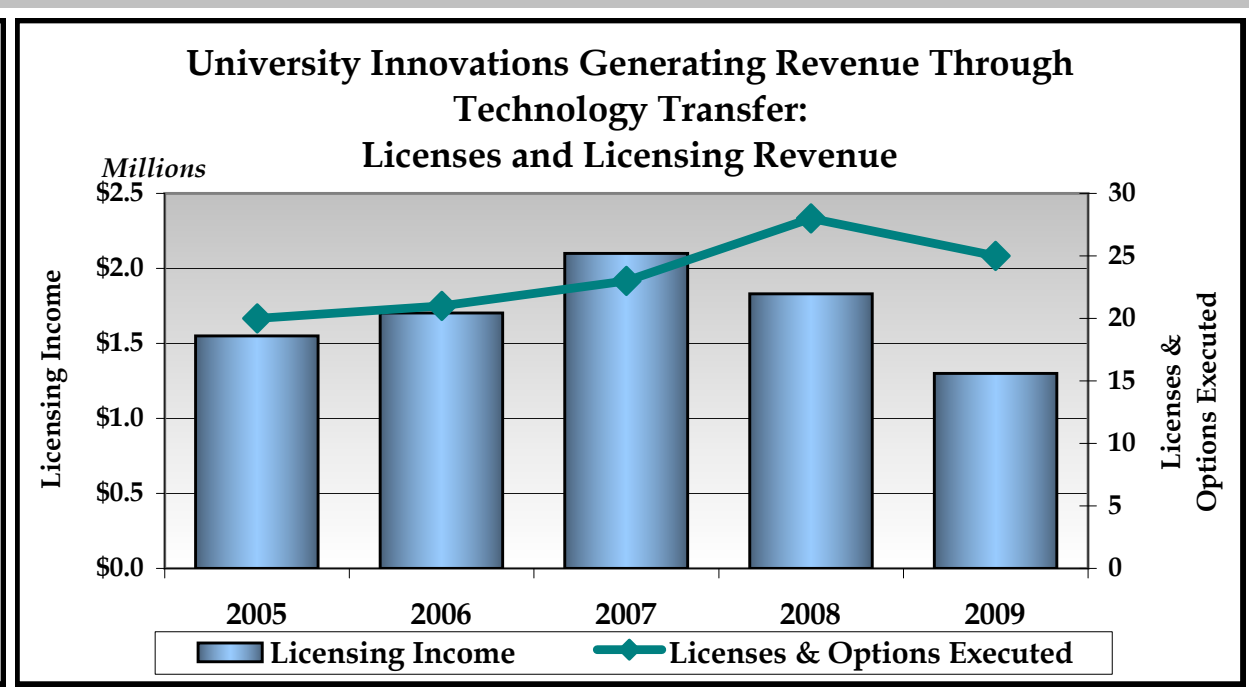

2011-12 Targets: Licenses - Increase (2008 Baseline = 23) Licensing Revenue - Increase (2008 Baseline $=\$ 2,099,712)$

University of South Florida - Page 4 


\section{Key University Achievements}

\section{Student awards/achievements}

1. Student Success: Total of 10,805 Degrees awarded; Bachelor's 7,863; Master's 2,543; Research Doctoral 243; Professional Doctoral 156.

2. Awards: Three Fulbright Scholars; Two Gillman Scholarships; One Javitz recipient; One BIG EAST Scholar; Short-listed World Architecture Design.

3. Awards: Two doctoral students NSF International Research \& Education in Engineering China program; one student placed top five winners in Chinese Bridge language competition.

\section{Faculty awards/achievements}

1. National Awards: Twelve faculty members received nationally recognized awards and five faculty received NSF CAREER awards, one a five-year award.

2. International Award: Jay Hopler recipient of a Rome Fellowship in Literature from the American Academy of Arts and Letters.

3. Fulbright Awards: Four research and administration.

\section{- Program awards/achievements}

1. Innovation: More than 100 inventors from across USF become members of National Academy of Inventors ${ }^{\mathrm{TM}}$.

2. New Programs: School of Global Sustainability (nation's first); College of Pharmacy; four doctoral programs.

3. New: Charter member of the Association for the Advancement of Sustainability in Higher Education.

\section{Research awards/achievements}

1. Partnerships: With Draper Laboratory, SRI Int., Mote Marine RI; hosts Florida Institute of Oceanography; houses Florida Center of Excellence for Biomolecular Identification and Targeted Therapeutics, partner Florida Energy Systems Consortium.

2. Grants $\mathcal{E}$ Patents: Total contracts and grants (FY10) $\$ 394.1$ million for research focusing in part on sustainability, neurosciences, diabetes, autoimmune diseases, and veterans' re-integration. USF was awarded $\$ 117$ million over five years by NIH for the Rare Disease Clinical Research Network; developed 66 new patents and licenses. Drug created and patented major partnership with global pharmaceutical company potentially earning USF lucrative patent royalties.

3. Rankings: USF ranked $110^{\text {th }}$ in the 2010 World University Rankings; $57^{\text {th }}$ of all universities and 33rd of public institutions for federal research awards (FY09).

\section{Institutional awards/achievements}

1. Community Response: Immediate response to Deepwater Horizon oil catastrophe $\$ 10$ million for research.

2. Donations: The USF Foundation raised over $\$ 51$ million from more than 44,000 donors (Total more than $\$ 363$ million).

3. Construction: New buildings on all four of its member institutions creating new employment opportunities. 


\section{BOARD OF GOVERNORS - STATE UNIVERSITY SYSTEM OF FLORIDA GOAL 4: MEETING COMMUNITY NEEDS AND FULFILLING UNIQUE INSTITUTIONAL RESPONSIBILITIES}

The University of South Florida is a major research university and continues to evolve into a model for the next generation of university systems for the state of Florida and the nation. The USF System now serves more than 47,000 students on campuses in Tampa, St. Petersburg, Sarasota-Manatee, and USF Polytechnic in Lakeland, each with distinctive missions. While USF has expanded its residential experience, it still is the top destination nationally for students transferring from other institutions to complete their bachelor's degrees.

The USF System is focused on five main strategic priorities: student success, research and innovation, community engagement, global literacy and impact, and integrated, interdisciplinary inquiry. Research firmly connects the University with the Tampa Bay community through service, outreach, and engagement activities; the corporate community through patenting and licensing of technology and targeted research; with academics through collaborative and cooperative programs; and globally through relationships with research colleagues. Research also connects the system through multidisciplinary approaches to common problems. Research provides opportunities to students, preparing them for success in their chosen fields or for graduate and professional education.

USF is one of only three Florida public universities classified by the Carnegie Foundation for the Advancement of Teaching in the top tier of research universities ( $\mathrm{RU} / \mathrm{VH}$ ), a distinction attained by only $2.2 \%$ of all universities (96 total: 63 publics, 33 privates) and is also one of 25 public research universities that holds both RU/VH and Engaged designations.

The USF Foundation raised over $\$ 51$ million from more than 44,000 donors, bringing the total amount raised on the USF: Unstoppable Campaign to more than $\$ 363$ million.

In furthering University interests, more than 100 inventors from across USF became members of National Academy of Inventors ${ }^{\mathrm{TM}}$.

Significantly, USF was uniquely placed to respond efficiently and effectively to the millions of gallons of oil that spewed into the Gulf beginning last April. From the outset, scientists and researchers from the USF's College of Marine Science mobilized to examine the spill, its potential flow patterns in the Gulf, and its impact on the environment. Research vessels outfitted with advanced equipment made frequent trips to gather valuable data. Scientists briefed members of Congress and USF experts were sought by the media. USF remains an agile and dynamic resource for all information on the Gulf of Mexico and the spill. 
RESOURCES, EFFICIENCIES, AND EFFECTIVENESS

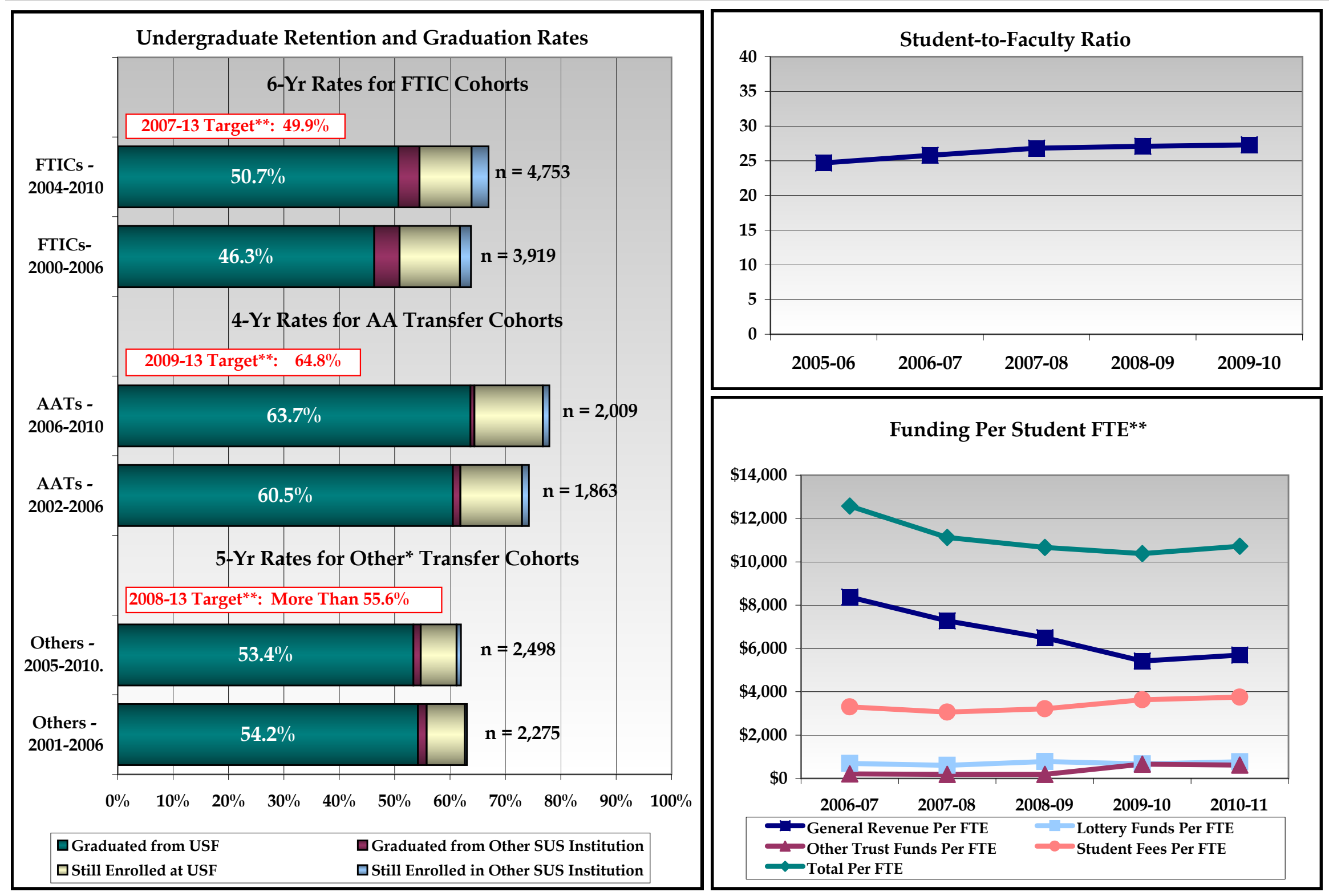

* The composition of "Other Transfer" cohorts may vary greatly by institution and by year.

** FTE for this metric uses the standard IPEDS definition of FTE, equal to 30 credit hours for undergraduates and 24 for graduates.

${ }^{* *}$ Graduation Rate from SAME Institution.

University of South Florida - Page 7 
This page is intentionally left blank.

University of South Florida - Page 8 


\section{The University of South Florida System}

\section{INTRODUCTION}

\section{Mission}

As Florida's only multi-campus university system, the University of South Florida is dedicated to adding value regionally, state-wide, nationally, and globally through enhancing access to higher education; advancing research which benefits society; contributing to regional unification; leveraging distinctive regional advantages; promoting partnership opportunities; assuring academic program quality; and providing consistently high quality support programs and services.

\section{Vision}

The USF System envisions itself as a leading multi-campus system of four separately accredited institutions with distinct and complementary missions that is a model for the next generation of university systems for Florida and nation.

\section{Other Contextual Introductory Comments}

The University of South Florida System is comprised of campuses in Tampa, St. Petersburg, Sarasota-Manatee, and USF Polytechnic in Lakeland with a focus on five strategic priorities: student success, research and innovation, community engagement, global literacy and impact, and integrated, interdisciplinary inquiry. The USF System offers rewarding opportunities as the regional campuses develop their particular niche and seek out relevant and appropriate Carnegie classifications.
The USF System embraces a unified vision of cooperative excellence with institutions, regional campuses, and direct service organizations developing distinct and complementary missions consistent with the overall USF mission. The USF System values existing collegial groups, including the Faculty Advisory Council, Student Government, A\&P Council, and Staff Senate that constructively contribute to the USF System strategic plan. The USF System is committed to working collaboratively with such groups to identify, develop and refine best practices on matters of shared interest. USF System: http://system.usf.edu/index.asp

\section{BOARD OF GOVERNORS - STATE UNIVERSITY SYSTEM GOAL 1: ACCESS TO AND PRODUCTION OF DEGREES}

The USF System provides access to an array of experiences to meet the different needs of its diverse clientele. From the very high research intensive doctoral campus, USF [in Tampa], to the distinctive master's-level campuses of USF St. Petersburg, USF Sarasota-Manatee, and USF Polytechnic, the system offers a range of college experiences in size, mission, and residency along with a wide selection of degree programs. Cooperative degree programs, innovative courses, interdisciplinary initiatives, and undergraduate and graduate research opportunities, presented across the system, add substantially to undergraduate and graduate student prospects and foster student success. Activities focus on the recruitment and retention of top-level students and highly qualified faculty to enhance learning effectiveness and degree production, improve student retention, and raise graduation rates. 
The USF System serves more than 47,000 students, offering 234 degree programs: 91 bachelor's, 99 master's, 2 Eds degrees, 38 research doctoral programs, and four professional doctorates. In 2009-10, the USF System awarded 10,805 degrees: Bachelor's 7,863; Master's 2,543; Research Doctoral 243; Professional Doctoral 156.

The USF System continues to shift undergraduate enrollment to its regional campuses as part of the University's plan to expand access and more clearly define the missions of each campus. USF St. Petersburg, the only regional campus that admits freshmen, enrolled 478 new freshmen in Fall 2009, an increase of nearly 37 percent from the previous year. Overall enrollments at the regional campuses were steady in 2009 in comparison with the previous year, with 1,906 students at Sarasota-Manatee and the 1,268, at USF Polytechnic.

Even with increased admission standards for transfer students, the USF System remains one of the nation's top destinations for transfer students. The USF System enrolls the most students transferring from the state's public community colleges, demonstrating its commitment to supporting Florida's ' $2+2$ ' system and the needs of transfer students.

At the graduate level, impressive trends can be seen with regard to the number of doctoral degrees awarded, a measure of USF's commitment to graduate education and the creation of new knowledge through research, scholarship, and creative activity. This prepares the nation's next generation of leaders, thinkers, and scientists by replenishing the ranks of the professoriate for American higher education.

Graduate and professional education in the USF System has been on a strong forward trajectory. Exemplary educational and research opportunities for graduates have been developed to promote our next state, national, and global leaders.

Overall, 35 percent of the USF System student body is comprised of students who identify themselves as ethnicities that are non-White. USF's student diversity is a hallmark of the institution and has been recognized by leading publications for a number of years.

\section{BOARD OF GOVERNORS - STATE UNIVERSITY SYSTEM GOAL 2: MEETING STATEWIDE PROFESSIONAL AND WORKFORCE NEEDS}

The USF System significantly impacts the Florida economy through its basic and applied research (funded by external grants and contracts), business, commercial and hightechnological innovations, new high skilled and high wage job creation, and community engaged scholarship. Development of public-private partnerships facilitates teaching and research that benefit communities throughout the state and beyond.

These partnerships include close ties with Draper Laboratory, SRI International, and the Mote Marine Research Institute. USF houses the Florida Center of Excellence for Biomolecular Identification and Targeted Therapeutics (FCoEBITT/CDDI), is host to the Florida Institute of Oceanography, and is an active partner in the Florida Energy Systems Consortium.

USF's commitment to applied research is evident by a $175 \%$ increase in the number of patents issued since 2004. The USF System generated 66 new patents and licensing agreements during the year, a significant development being the creation and patenting of a drug in partnership with AstraZeneca PLC 
and Targacept, Inc., potentially earning the University lucrative patent royalties.

The USF System promotes synergies among its members, serving as a major economic engine for the region and the state, by challenging its institutions to increase the production of talented graduates in targeted, high demand fields; increase basic and applied research supported by the private sector and external funding; incubate a significant number of new companies, patents, and licensing revenues; and enhance the quality of life through medical breakthroughs.

The USF System has a national and international impact that promotes the state's economic development and helps place it on the global stage. The USF System continues to expand its global activities, international faculty exchanges, recruitment of full fee-paying international students, student education abroad programs, research collaborations, and service learning, thus boosting Florida's international competitiveness and place in the global economy. The USF System advances close partnerships with institutions of higher education from around the world providing additional opportunities in teaching and research for students and faculty, as well as preparing globally engaged graduates who compete successfully in the global marketplace of ideas.

As a leading research university, USF System offers an array of undergraduate and graduate degree programs preparing students to become leaders in business, industry, service, and research. Many degree programs align with state goals to meet professional and workforce needs, including education, health professions, the sciences, and emerging technologies.
Following the guidelines and selection of areas of strategic emphasis identified by the Board of Governors in consultation with business and industry groups, between 2004 and 2008, the USF System has experienced a positive growth in all identified areas (Education, Health Professions, STEM areas, Security \& Emergency Services, and Globalization). From 2005 to 2009, USF had a 33\% increase in total bachelor degrees awarded for all areas of strategic emphasis.

\begin{tabular}{|l|c|c|c|c|c|c|}
\hline USF SYSTEM & $\mathbf{2 0 0 5}$ & $\mathbf{2 0 0 6}$ & $\mathbf{2 0 0 7}$ & $\mathbf{2 0 0 8}$ & $\mathbf{2 0 0 9}$ & $\mathbf{2 0 0 5 - 0 9}$ \\
\hline Education & 97 & 94 & 105 & 112 & 105 & $\mathbf{8 \%}$ \\
\hline Health Prof. & 339 & 443 & 420 & 435 & 437 & $\mathbf{2 9 \%}$ \\
\hline STEM & 1127 & 1255 & 1299 & 1395 & 1536 & $\mathbf{3 6 \%}$ \\
\hline Security/Emerg & 337 & 366 & 394 & 412 & 458 & $\mathbf{3 6 \%}$ \\
\hline Globalization & 377 & 427 & 445 & 470 & 490 & $\mathbf{3 0 \%}$ \\
\hline Total & 2277 & 2585 & 2663 & 2824 & 3026 & $\mathbf{3 3 \%}$ \\
\hline
\end{tabular}

\section{BOARD OF GOVERNORS - STATE UNIVERSITY SYSTEM GOAL 3: BUILDING WORLD-CLASS ACADEMIC PROGRAMS AND RESEARCH CAPACITY}

Research is a hallmark of every college, department, and program at the USF System. It is an expectation and a privilege of every faculty member, whether sponsored by external funding or carried out with support of University resources. As a result, there are many projects investigating basic research problems and tackling applied societal challenges that together enhance our understanding of the world in the creation of new knowledge. Research, then, is a centerpiece of the University's strategic plan, is fundamental 
to the recruitment and retention of top faculty and gives the University distinction.

Consistent with the USF Strategic Plan, the University has four internationally recognized research themes which span the system: sustainability; integrated neurosciences; diabetes; and drug design, development, and delivery. Home to Florida's second public medical school, USF's focus on health education and research is a hallmark of the USF System's unique contributions to health disciplines and the public.

USF ranked 110th in the 2010 World University Rankings of the top performing, high impact research universities as measured by the performance index based on publications and citations of research. Under the basic classification of the Carnegie Foundation, USF is ranked in the highest category - a Research University with very high research activity $(\mathrm{RU} / \mathrm{VH})$ that grants doctoral degrees. This classification reflects the distinguished quality of academic programs and research capacity, and the contributions they make to the creation of knowledge and technological innovation in building Florida's new economy. Adding to this is the importance and impact of applied research taking place on the distinctive and missiondriven regional institutions/campuses.

USF's research enterprise is also remarkable on the national level. In FY 2008, USF ranked $64^{\text {th }}$ of total research and development expenditures (external funding) for all colleges and universities and $43^{\text {rd }}$ of all public institutions. In FY 2009, USF ranked $33^{\text {rd }}$ in federal research expenditures for public universities and 57th for all universities. In FY 2010, USF's funded research generated \$394.1 million in external awards from federal, state, industry, foundation, and other sponsors who are USF's partners in discovery and innovation that benefits Floridians; develops and commercializes products, knowhow, and processes; and creates start-up companies and jobs.

In 2009-10, three members of the USF faculty were identified as national academy members; 12 received nationally prestigious faculty awards as defined by the Top American Research Universities (TARU); and five received NSF CAREER awards. In addition, one faculty member was awarded the Rome Fellowship in Literature from the American Academy of Arts and Letters.

A reflection of the USF System student success initiative, students were awarded three Fulbright Scholarships; two Gillman Scholarships; and one Javitz award. In addition, one student was named a BIG EAST scholar; Architecture students were short listed for World Architecture Design Award; two doctoral students were selected NSF International Research \& Education in Engineering China program; and one student placed among top five winners at world Chinese Bridge language competition. An overview of USF's 2009-10 Student \& Faculty Awards:

http://usfweb3.usf.edu/infocenter/?report_category=SUR

\section{BOARD OF GOVERNORS - STATE UNIVERSITY SYSTEM GOAL 4: MEETING COMMUNITY NEEDS AND FULFILLING UNIQUE INSTITUTIONAL RESPONSIBILITIES}

The University of South Florida is a major research university and continues to evolve into a model for the next generation of university systems for the state of Florida and the nation. The USF System now serves more than 47,000 students on 
campuses in Tampa, St. Petersburg, Sarasota-Manatee, and USF Polytechnic in Lakeland, each with distinctive missions. While USF has expanded its residential experience, it still is the top destination nationally for students transferring from other institutions to complete their bachelor's degrees.

The USF System is focused on five main strategic priorities: student success, research and innovation, community engagement, global literacy and impact, and integrated, interdisciplinary inquiry. Research firmly connects the University with the Tampa Bay community through service, outreach and engagement activities, the corporate community through patenting and licensing of technology and targeted research, with academics through collaborative and cooperative programs, and globally through our relationships with research colleagues. Research also connects the system through multidisciplinary approaches to common problems. Research provides opportunities to students, preparing them for success in their chosen fields or for graduate and professional education.

USF is one of only three Florida public universities classified by the Carnegie Foundation for the Advancement of Teaching in the top tier of research universities (RU/VH), a distinction attained by only $2.2 \%$ of all universities (96 total: 63 publics, 33 privates) and is also one of 25 public research universities that holds both RU/VH and Engaged designations.

The USF Foundation raised over $\$ 51$ million from more than 44,000 donors, bringing the total amount raised on the USF: Unstoppable Campaign to more than $\$ 363$ million.
In furthering University interests, more than 100 inventors from across USF became members of National Academy of Inventors ${ }^{\mathrm{TM}}$.

Significantly, USF was uniquely placed to respond efficiently and effectively to the millions of gallons of oil that spewed into the Gulf beginning last April. From the outset, scientists and researchers from the USF's College of Marine Science mobilized to examine the spill, its potential flow patterns in the Gulf, and its impact on the environment. Research vessels outfitted with advanced equipment made frequent trips to gather valuable data. Scientists briefed members of Congress and USF experts were sought by the media. USF remains an agile and dynamic resource for all information on the Gulf of Mexico and the spill.

\section{PROGRESS ON PRIMARY INSTITUTIONAL GOALS AND METRICS AS OUTLINED IN THE UNIVERSITY WORK PLAN}

The following is a brief synopsis highlighting some of the progress made on institutional goals at the four campuses that comprise the University of South Florida System. Further details can be found in the individual campus-level reports.

\section{$\underline{\mathrm{USF}}$}

USF serves as the core institution to the USF System but works collaboratively with the other three institutions to provide distinction in teaching, research, and service. USF is a leading metropolitan research university, dedicated to excellence in:

- Student access and success in an engaged, and interdisciplinary, learner-centered environment; 
- Research and scientific discovery, including the generation, dissemination, and translation of new knowledge across disciplines; to strengthen the economy; to promote civic culture and the arts; and to design and build sustainable, healthy communities; and

- Embracing innovation, and supporting scholarly and artistic engagement to build a community of learners together with significant and sustainable universitycommunity partnerships and collaborations.

USF's strategic plan guides the institution's advancement (http:// www.ods.usf.edu/Plans/Strategic) with five goals:

Goal 1: Student access and success;

Goal 2: Expanding world-class interdisciplinary research, creative, and scholarly endeavors;

Goal 3: Promoting globally competitive undergraduate, graduate, and professional programs that support interdisciplinary inquiry, intellectual development, knowledge and skill acquisition, and student success through a diverse, fully- engaged, learner-centered campus environment;

Goal 4: Expanding local and global engagement initiatives to strengthen and sustain healthy communities and to improve the quality of life; and

Goal 5: E nhancing all sources of revenue, and maximizing effectiveness in business practices and financial management to establish a strong and sustainable economic base in support of USF's growth.
USF continues to make remarkable progress on its primary institutional goals. This can be seen from a quantitative perspective as shown in the array of data displayed on its dashboard and in the detailed matrix of variables through which the institution gauges its progress, as well as through qualitative advances, some of which are described below.

- USF Dashboard:

http://www.ods.usf.edu/Plans/PPA/dashboard.htm

- USF Matrix:

http://www.ods.usf.edu/Plans/PPA/matrix.htm

- Performance Update: Advancing USF's Strategic Plan, http://www.ods.usf.edu/Support/2010-10-07BOT/AAU-performance-update.htm

A few examples of progress in these goals are highlighted below:

INTO USF: USF and INTO University Partnerships embarked on a joint venture to increase international student recruitment at USF and ensure greater student success. The INTO >>USF international study center, based at USF, offers a range of programs that helps the USF System capitalize on the growing number of international students seeking to study in the USA. The innovative year-long preparation courses provide international students with academic, English, and cultural skills needed for successful study in American universities.

School of Global Sustainability: USF launched the School of Global Sustainability, one of the nation's first, in February 2010, an innovative effort aimed at preparing students for a new generation of "green collar" careers and finding solutions for a world challenged with the protection of its fragile environment and limited resources. The first degree program 
to be offered by the school is an MA in Global Sustainability to prepare students to address complex regional, national, and global challenges related to sustainability and the ability to innovate in diverse cultural, geographic, and demographic contexts. The multi-disciplinary program incorporates the natural and social sciences, engineering, health, economics, governance and policy, and issues of diversity.

Global Academic Partners Program (GAP): The GAP Program provides for mutually beneficial collaboration in research, teaching, and creative activities between USF and its GAP Universities. Current partners are Nankai University and Ocean University in China, University of Exeter in the United Kingdom, University of Ghana, and University of the Cape Coast, in Ghana. Fostering better international relations will facilitate connections between countries and hence facilitate economic development.

\section{See USF's SUS Annual Report for additional information.}

\section{USF St. Petersburg}

USF St. Petersburg's strategic plan identifies three primary goals:

Goal 1: Enhance learning and achievement and promote student retention through curricular and co-curricular programs. Metrics include: Retention rate year to year; $4 / 5 / 6$ year graduation rate; ratio of academic advisors to students; number of $\mathrm{D} / \mathrm{F} / \mathrm{W}$ grades in key entry level courses (College Algebra, English Composition); number of students accepted to/enrolled in post-baccalaureate training or employed within one year of graduation; increased student satisfaction with academic advising.
- One full-time additional academic advisor hired and another selected for a total of 9 advisors for about 3,900 students. This will reduce student:advisor ratio to about 430:1 from 487:1, very near the goal of 425:1.

- Completion of the Quality Enhancement Plan (QEP) focused on enhanced student learning in key mathematics courses is on schedule for December 2011. This Plan is required by the Southern Association of Colleges and Schools. A QEP Director is expected to be hired prior to the On-Site Review Team accreditation visit in February, 2011. The QEP focuses on a model to reduce the percentage of students with $\mathrm{D} / \mathrm{F} / \mathrm{W}$ grades in three "gateway" courses: College Algebra, Finite Mathematics, and Elementary Statistics.

- Two searches for new faculty in key science disciplines are underway to strengthen course offerings in the sciences which will assist students in being more competitive for post-baccalaureate training and employment. The faculty to student ratio at USFSP is $24: 1$, compared to a USF System wide average of 27:1.

- Four additional tutor positions approved for hiring.

Goal 2: Increase faculty and student research and creative activities. Metrics include: Total externally funded research/ sponsored programs annually; number of large awards (over $\$ 100,000)$ annually; number of proposals written; percentage of proposals awarded; number of publications in peer-refereed journals/books/monographs; number of faculty publications with student (graduate or undergraduate) co-authors; number of student presentations at local/regional/national/ international conferences; number of proposal/awards and/or publications with non-USFSP co-authors/co-investigators.

- Total externally funded research/sponsored programs rose over 20\% from $\$ 1.7 \mathrm{M}$ in 2008-09 to $\$ 2.1 \mathrm{M}$ in 2009-10. 
- Number of large awards (over $\$ 100,000)$ rose from 1 in 2008-09 to 4 in 2009-10.

- Student research journal (electronic) is under construction.

- Increased investment in undergraduate research and creative activities; student presentations during USFSP research month rose from 33 in 2008-09 to 221 in 2009-10.

- Faculty peer-refereed publications rose 16\% from 2009-10.

Goal 3: Initiate construction of the Multipurpose Campus Center. Metrics include: Enhanced student satisfaction through surveys such as NSSE and CIRP; greater numbers of student organizations and measurement of the impact on campus life and the community (through surveys of entities such as the St. Petersburg Downtown Partnership); enhanced revenues from residential occupancy and dining.

- Legislation approved to raise fee cap - Florida Legislature

- Student fee increase approved for this facility and is now being collected (as of Fall 2010 semester)

- Financial Plan approved by the USF Board of Trustees.

- The Financial plan submitted to the SUS/BOG

See USF St. Petersburg's SUS Annual Report

\section{$\underline{\text { USF Polytechnic }}$}

In 2009, an update on the USF Polytechnic Strategic Plan was approved by the USF Board of Trustees:

Goal 1: Recruit, develop, and retain world-class practitioner scholars with capacity to deliver the polytechnic vision in teaching, research, and community engagement.

- Twenty-two new faculty hired in AY 2009-2010 from high quality institutions. A faculty hiring plan for AY 20102011 includes 37 new faculty positions in the areas of
Communication and New Media, Criminology, Educational Leadership, Elementary Education/ESOL, Elementary Education/Literacy, Experimental Psychology, Industrial Psychology, Biology/Microbiology, Chemistry, Health Informatics, Mathematics, Physics, Marketing, Finance, Statistics, Management, Information Systems, Accounting, Engineering and Information Technology, and Architecture.

Goal 2: Recruit students locally, nationally, and internationally who are prepared for a polytechnic learning environment, and provide programs and opportunities that enhance student retention and academic, personal, and professional success.

Goal 3: Expand and create academic programs that focus on applied learning, applied research, applied technology, and interdisciplinary approaches in a polytechnic model. Develop and implement new degree programs in five areas of distinction: applied health sciences; mathematics and science education; business and entrepreneurship; manufacturing engineering and technology; and information technology.

Goal 4: Implement the Campus Master Plan and develop a campus infrastructure to support a polytechnic learning and research environment, and develop a stable economic base for continued program development as a polytechnic campus.

An updated Campus Master Plan was presented to the USF Board of Trustees in October 2009. The following progress has been made on the implementation of that plan with public and private investment:

- Dr. Santiago Calatrava, a product of several polytechnic universities in Europe, was selected as the architect for the 
new I-4 campus. The facility will establish an open, multipurpose design in support of interdisciplinary and collaborative learning environment foundational to a polytechnic experience for students. It will focus on sustainability and synergy with the natural environment. Construction for infrastructure began in late spring 2010, while construction of Phase I facilities will begin in fall 2011 with a projected occupancy of summer 2013.

- Polk County Investment \$11.7 million. Polk County designed and constructed a four-lane access creating a major entrance gateway to the campus from the east.

- State of Florida Turnpike Authority Investment \$31.9 M; Williams Company \$9.4 million. The Turnpike Authority recognized the need for access via the Polk Parkway. A pledge has been made to create a $\$ 32 \mathrm{M}$ exit interchange at Pace Road (in partnership with the Williams Company). Completion - December 2011.

- Florida Department of Transportation Investment \$28 million to provide access from the west for the largest concentration of constituents. The Florida DOT, with City of Lakeland and Transportation Planning Council of Polk County, identified the East/West Road project as their Number 1 priority. Completion - December 2011.

- Polk County invested an additional \$10 million toward the university ring road and part of overall site infrastructure.

- PECO State Funds \$31.2 million (received); an additional $\$ 35$ million was anticipated in 2010. Investments from Private Sources \$10.7 million with anticipated FEGC match. These funds will build the first facility on the campus (Phase I), the Science \& Technology Building, as well as a portion of the campus infrastructure.

- PECO request \$5 million; Private Investment \$5 million (pledged 3 years, first year received) eligible for FECG match. Funds will build the Interdisciplinary Center for
Wellness Education and Research, a multi-purpose facility exemplifying the ideal blend of Town and Gown, bringing the general public and the campus community together around wellness issues, education, and research.

- Private Investment \$1million (received). Interdisciplinary, applied learning, and research in a polytechnic environment brings the prospect of engaging creative, entrepreneurial energies in the high technology arena of Central Florida, as well as engaging polytechnic students in related educational experiences. The Campus Master Plan includes development of a High Tech incubator and development of an applied learning laboratory where students and aspiring entrepreneurs will work together in development of new ideas and application of established and emerging research to bring about innovation.

Goal 5: Develop collaborative public and private partnerships that enhance funding opportunities, including leveraging state and federal funding.

\section{See USF Polytechnic's SUS Annual Report}

\section{USF Sarasota-Manatee}

The USF Sarasota-Manatee has six goals:

Goal 1: Learner-Centered Environment: Be a diverse, collaborative, and intellectually challenging campus with high quality academic programs and support services for students, faculty, staff, and community. With strategic focus on teaching and learning, research, programming, campus climate, and community, USF Sarasota-Manatee has met and seeks to exceed its objectives for this goal. 
- Presently, 75\% of USF Sarasota-Manatee student credit hours are taught by full-time resident faculty. The campus will maintain this percentage with a goal of higher ratios once funding for additional faculty becomes available.

- Likewise, $75 \%$ of USF Sarasota-Manatee faculty members teaching undergraduate students have the doctorate degree in the discipline in which they are teaching.

Goal 2: Technology: Provide and encourage strategic use of electronic learning technology.

- Student convenience and teaching and learning enhancement foci have resulted in $9 \%$ increase in number of distance learning courses in 2009-10 over 2008-09 levels.

- Continued focus of curricular efforts on using technology to develop convenient schedules for student learning, such as online courses, distance learning, and hybrid courses.

Goal 3: Program Growth: Promote expansion of distinctive upper-division baccalaureate, master's, and research initiatives that serve local and global needs.

- In seeking separate accreditation, USF Sarasota-Manatee has worked to ensure degree programs are complete and that students have access to resident faculty and a full course schedule to ensure timely degree obtainment.

- Plans to increase the number of programs offered in the near future. In concert with the release of the 2010 census data, USF Sarasota-Manatee will conduct a comprehensive environmental scan of the three-county area to identify educational needs and growing markets.

Goal 4: Professional and Continuing Education: Provide advanced professional and continuing education that serves community needs.
- Continued efforts to meet workforce and professional development needs in Sarasota, Manatee, DeSoto counties.

- College of Business and the Institute for Public Policy and Leadership provided continuing education credits.

Goal 5: Financial Stability: Grow and diversify resource base.

- USF Sarasota-Manatee will be seeking \$2 million each year for the next three years from the State Legislature to support the separate accreditation process and to grow into a four-year degree institution. Funds will be used to hire additional faculty to teach general education courses and pre-requisite courses in business and education.

Goal 6: Assessment: Expand the system of self-study and continuous improvement.

- USF Sarasota-Manatee is committed to self-assessment in both its academic programs and administrative units. 2009-10 marked the third cycle of academic assessment within the newly autonomous USFSM Colleges.

See USF Sarasota-Manatee's SUS Annual Report

\section{ADDITIONAL INFORMATION ON QUALITY, RESOURCES, EFFICIENCIES, AND EFFECTIVENESS}

\section{USF System}

The USF System provides central services through several offices: 1) Audit \& Compliance, 2) Diversity \& Equal Opportunity, 3) General Counsel, 4) Government Relations, and 5) Special Events and Ceremonies. An annual cost allocation for services from these offices is distributed to each campus in the USF System to ensure consistency in 
implementation of USF System regulations and policies and to avoid duplication of the system-wide central services.

\section{$\underline{\text { USF }}$}

Other USF offices also provide services to all campuses within the USF System, for example: 1) Enterprise business systems, e.g., FAST, GEMS, FAIR for student, employee, and financial data; 2) purchasing and accounting; 3) Research and Innovation for research compliance and grant/contract proposals, awards and management; 4) USF Libraries; 5) Financial Aid; 6) International Affairs; 7) Decision Support; 8) University Advancement; 9) Information Technology; 10) Communications and Marketing. Again, an annual cost allocation for services from these offices is distributed to each campus in the USF System.

\section{USF St. Petersburg}

USF St. Petersburg has re-engineered many of its processes and reorganized its administrative functions to increase efficiency and deliver outstanding student services with reduced resources. For example, Academic Affairs and Student Affairs realigned admissions, financial aid, registration and records, and student academic support (tutoring center) functions to enable better service to more students with fewer people.

USFSP reduced costs by moving a large number of personnel from leased to university-owned space. USFSP has reduced its energy consumption $11 \%$ since 2007 saving nearly $\$ 200,000$.

Personnel efficiencies in administrative areas: Parking and Purchasing functions consolidated into one position; facilities planning and facilities maintenance functions combined into single department; and cross-training of cashiers, purchasing and parking staff resulted in more efficient operations.

Environmentally friendly practices such as greatly reduced paper consumption, and conversion to eco-friendly cleaning products and maintenance have resulted in more effective operations consistent with USFSP's strategic goal of environmental stewardship.

\section{USF Polytechnic}

Over the last four years USF Polytechnic saved approximately $\$ 300,000$ in telecommunication costs with the implementation of a high function, integrated phone system. USF Polytechnic has created additional recurring savings by moving toward convergent networks integrating operational systems (i.e., Video, Voice, Data, Security cameras, keycard access systems) into the infrastructure of the network removing the necessity to have separate cabling and additional equipment for each service. The Campus Executive Officer has raised more than $\$ 35$ million in private support for the campus master plan.

\section{USF Sarasota-Manatee}

USF Sarasota-Manatee continues to make savings to become more efficient. One example shows that the institution has reduced its electrical KWH demand by $21 \%$ since 2006-2007. 


\section{ADDITIONAL RESOURCES}

- Carnegie Classification

o Basic: RU/VH: Research Universities (very high research activity)

o Community Engagement: Outreach \& Partnerships

o Undergraduate Instructional Program:

CompDoc/MedVet: Comprehensive doctoral with medical/veterinary

o Graduate Instructional Program: Bal/HGC: Balanced arts \& sciences/professions, high graduate coexistence

o Enrollment Profile: HU: High undergraduate

o Undergraduate Profile: MFT4/S/HTI: Medium fulltime four-year, selective, higher transfer-in

o Size and Setting: L4/NR: Large four-year, primarily nonresidential

http://www.carnegiefoundation.org/classifications/

- Voluntary System of Accountability College Portrait of Undergraduate Education

http://www.collegeportraits.org/FL/USF

- Common Data Set

http://usfweb3.usf.edu/infocenter/?silverheader=2\&repo rt_category $=$ SUR\&report_type $=$ CDSUR

- College Navigator

http://nces.ed.gov/collegenavigator/?q=South+Florida\& $\underline{\mathrm{s}=\mathrm{FL} \& \mathrm{id}=137351}$

- USF Office of Research \& Innovation http:/ / www.research.usf.edu/

- University Strategic Plan http:// system.usf.edu/pdfs/USF_System_Strategic_Plan. pdf
- Comparative Data

o Performance Update: Advancing USF's Strategic Plan, http://www.ods.usf.edu/Support/2010-10-07BOT/AAU-performance-update.htm )

- University Data Sources

o USF Planning, Performance and Accountability: http://www.ods.usf.edu/Plans/PPA/matrix.htm

o USF e-Profiles: http://usfweb3.usf.edu/eprofiles/

o USF InfoCenter: http://usfweb3.usf.edu/infocenter/

o USF Performance Dashboard: http://www.ods.usf.edu/Plans/PPA/dashboard.htm

o USF Peers: http://www.ie.usf.edu/Peer/ 



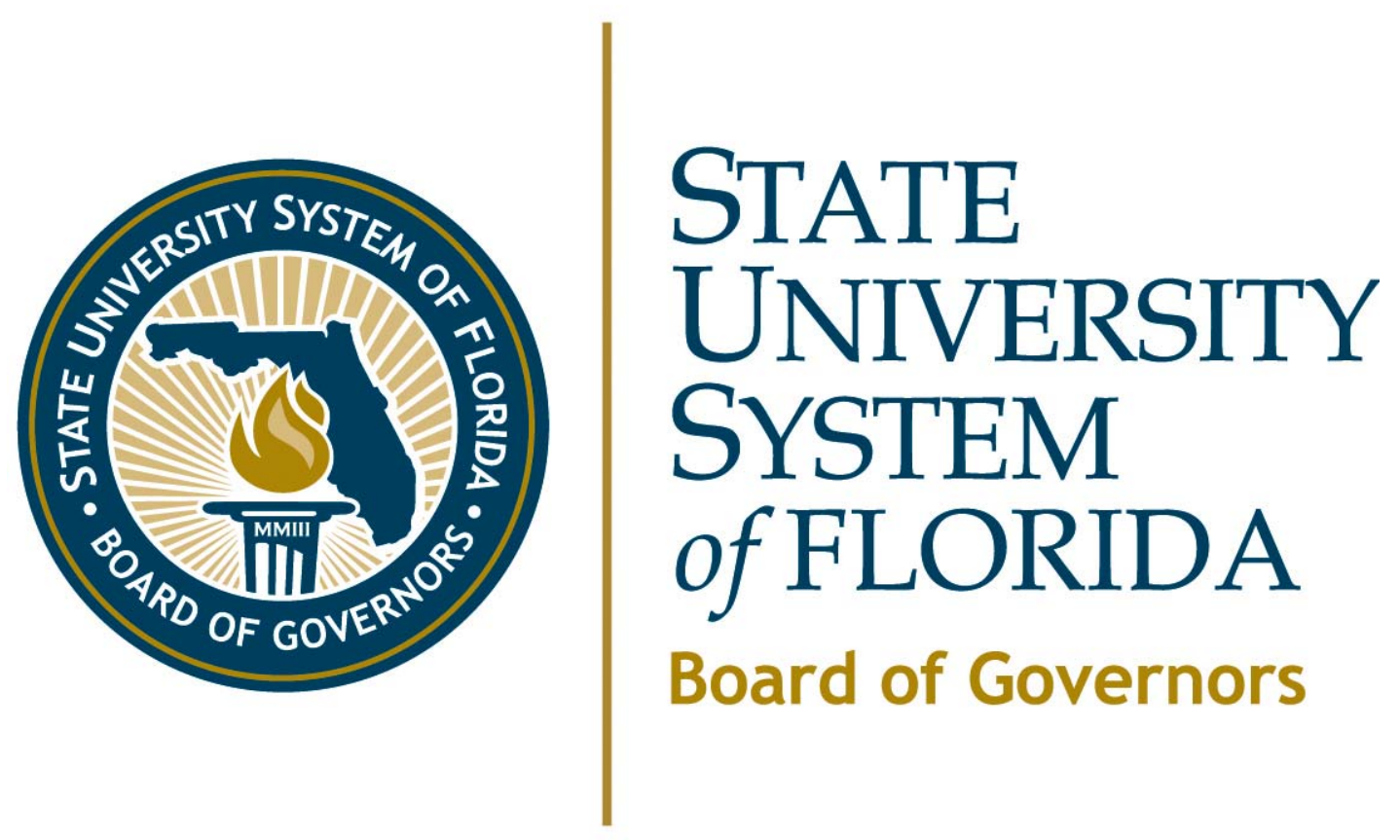

2010 Annual Report

Volume II 
This page is intentionally left blank. 


\section{Annual Report}

Data Tables [Not every university will have every table.]

\section{Section 1 - Financial Resources}

TABLE 1A. University Education and General Revenues

TABLE 1B. University Education and General Expenditures

TABLE 1C. State Funding per Full-Time Equivalent (FTE)

$$
\text { Student }
$$

TABLE 1D. University Other Budget Entities

TABLE 1E. University Total Revenues and Expenditures

TABLE 1F. Voluntary Support of Higher Education

TABLE 1G. University Federal Stimulus Dollars (ARRA)

\section{Section 2 - Personnel}

TABLE 2A. Personnel Headcount

\section{Section 3 - Enrollment}

TABLE 3A. University Full-Time Enrollment (FTE)

TABLE 3B. Enrollment by Location

\section{Section 4 - Undergraduate Education}

TABLE 4A. Baccalaureate Degree Program Changes in AY 2009-

$$
2010
$$

TABLE 4B. First-Year Persistence Rates

TABLE 4C. Federal Definition - Undergraduate Progression and Graduation Rates for Full-Time First-Time-inCollege (FTIC) Students

TABLE 4D. SUS Definition - Undergraduate Progression and Graduation Rates for First-Time-in-College (FTIC) Students

TABLE 4E. SUS Definition - Undergraduate Progression and Graduation Rates for AA Transfer Students

\section{Section 4 - Undergraduate Education (continued)}

TABLE 4F. SUS Definition - Undergraduate Progression and Graduation Rates for Other Transfer Students

TABLE 4G. Baccalaureate Degrees Awarded

TABLE 4H. Baccalaureate Degrees Awarded in Areas of Strategic Emphasis

TABLE 4I. Baccalaureate Degrees Awarded to Underrepresented Groups

TABLE 4J. Baccalaureate Completion Without Excess Credit Hours

TABLE 4K. Undergraduate Course Offerings

TABLE 4L. Faculty Teaching Undergraduates

TABLE 4M. Undergraduate Instructional Faculty Compensation

TABLE 4N. Student/Faculty Ratio

TABLE 4O. Professional Licensure Exams - Undergraduate Programs

TABLE 4P. Tuition Differential Fee

\section{Section 5 - Graduate Education}

TABLE 5A. Graduate Degree Program Changes in AY 2009-2010

TABLE 5B. Graduate Degrees Awarded

TABLE 5C. Graduate Degrees Awarded in Areas of Strategic Emphasis

TABLE 5D. Professional Licensure Exams - Graduate Programs

\section{Section 6 - Research and Economic Development}

TABLE 6A. Research and Development

TABLE 6B. Centers of Excellence

TABLE 6C. State University Research Commercialization Assistance Grants

TABLE 6D. 21st Century World Class Scholars Program 
This page is intentionally left blank. 


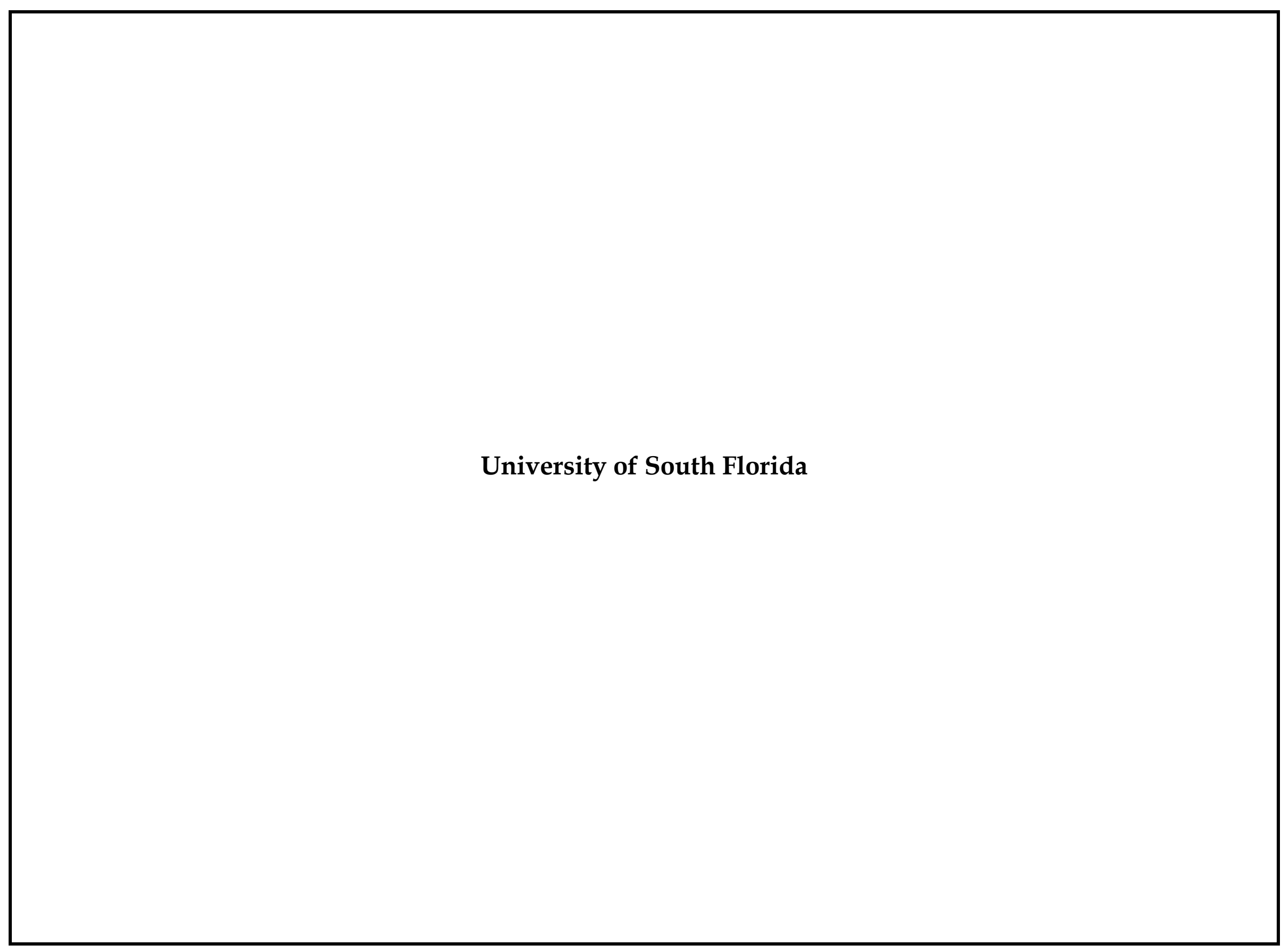


Data definitions are provided in the Appendices.

Note concerning data accuracy: The Office of the Board of Governors believes that the
accuracy of the data it collects and reports is paramount to ensuring accountability in the
State University System. Thus, the Board Office allows university resubmissions of some data
to correct errors when they are discovered. This policy can lead to changes in historical data. 
Section 1 - Financial Resources

\begin{tabular}{|l|r|r|r|r|r|}
\hline TABLE 1A. University Education and General Revenues \\
\hline & $\begin{array}{c}\mathbf{2 0 0 6 - 0 7} \\
\text { Actual }\end{array}$ & $\begin{array}{c}\text { 2007-08 } \\
\text { Actual }\end{array}$ & $\begin{array}{c}\text { 2008-09 } \\
\text { Actual }\end{array}$ & $\begin{array}{c}\mathbf{2 0 0 9 - 1 0} \\
\text { Actual }\end{array}$ & $\begin{array}{c}\mathbf{2 0 1 0 - 1 1} \\
\text { Estimates }\end{array}$ \\
\hline $\begin{array}{l}\text { Recurring } \\
\text { State Funds } \\
\text { (GR \& Lottery) }\end{array}$ & $\$ 279,243,714$ & $\$ 291,560,395$ & $\$ 269,447,277$ & $\$ 241,841,349$ & $\$ 261,765,867$ \\
\hline $\begin{array}{l}\text { Non-Recurring } \\
\text { State Funds } \\
\text { (GR \& Lottery) }\end{array}$ & $\$ 41,423,885$ & $\$ 8,671,511$ & $\$ 11,937,078$ & $\$ 1,585,518$ & $\$ 2,173,018$ \\
\hline $\begin{array}{l}\text { Tuition } \\
\text { (Resident \& Non-Resident) }\end{array}$ & $\$ 104,174,513$ & $\$ 109,722,907$ & $\$ 112,352,760$ & $\$ 118,853,735$ & $\$ 124,244,300$ \\
\hline Tuition Differential Fee & $\$ 0$ & $\$ 0$ & $\$ 2,626,024$ & $\$ 7,458,495$ & $\$ 14,135,844$ \\
\hline $\begin{array}{l}\text { Other Revenues } \\
\text { (Includes Misc. Fees \& Fines) }\end{array}$ & $\$ 3,259,132$ & $\$ 3,870,454$ & $\$ 3,862,283$ & $\$ 3,802,375$ & $\$ 3,415,994$ \\
\hline $\begin{array}{l}\text { Phosphate Research } \\
\text { Trust Fund }\end{array}$ & $\$ 7,141,734$ & $\$ 7,268,856$ & $\$ 7,287,963$ & $\$ 7,304,874$ & $\$ 7,312,164$ \\
\hline Federal Stimulus Funds & $\$ 0$ & $\$ 0$ & $\$ 0$ & $\$ 18,790,945$ & $\$ 17,980,176$ \\
\hline TOTAL & $\mathbf{\$ 4 3 5 , 2 4 2 , 9 7 8}$ & $\mathbf{\$ 4 2 1 , 0 9 4 , 1 2 3}$ & $\mathbf{\$ 4 0 7 , 5 1 3 , 3 8 5}$ & $\mathbf{\$ 3 9 9 , 6 3 7 , 2 9 1}$ & $\mathbf{\$ 4 3 1 , 0 2 7 , 3 6 3}$ \\
\hline
\end{tabular}

\begin{tabular}{|c|c|c|c|c|c|}
\hline & $\begin{array}{l}2006-07 \\
\text { Actual }\end{array}$ & $\begin{array}{c}\text { 2007-08 } \\
\text { Actual }\end{array}$ & $\begin{array}{r}2008-09 \\
\text { Actual }\end{array}$ & $\begin{array}{r}2009-10 \\
\text { Actual }\end{array}$ & $\begin{array}{c}2010-11 \\
\text { Estimates }\end{array}$ \\
\hline Instr & $259,117,057$ & $\$ 254,025,777$ & $232,420,538$ & $\$ 248,178,440$ & 41 \\
\hline & $\$ 1,234,810$ & $\$ 1,193,342$ & $\$ 1,024,089$ & $\$ 968,072$ & $\$ 773,6$ \\
\hline 108 & & & & 8 & 38 \\
\hline & $\$ 23,274,704$ & $\$ 21,181,757$ & $\$ 28,501,983$ & $\$ 23,730,020$ & $\$ 41,389,142$ \\
\hline & & & & & \\
\hline L & 48 & 25 & 14 , & 694 & 379 \\
\hline $\mathrm{Mu}$ & 217 & 454 & 951 & 0,699 & 476 \\
\hline Agri & $\$ 0$ & $\$ 0$ & $\$ 0$ & $\$ 0$ & $\$ 0$ \\
\hline Stud & $14,779,771$ & $\$ 22,958,049$ & $\$ 22,054,934$ & $\$ 21,924,396$ & $\$ 21,228,899$ \\
\hline Inter & & $\$ 513,486$ & & $\$ 356,212$ & \\
\hline TOTA & $353,268,196$ & $\$ 354,692,171$ & $\$ 336,164,207$ & $\$ 346,659,904$ & $\$ 440,659,655$ \\
\hline \multicolumn{6}{|c|}{$\begin{array}{l}\text { The table reports the actual and estimated amount of expenditures from revenues appropriated by the } \\
\text { Legislature for each fiscal year. The expenditures are classified by Program Component (i.e., } \\
\text { Instruction/Research, PO\&M, Administration, etc.) for activities directly related to instruction, research } \\
\text { and public service. The table does not include expenditures classified as non-operating expenditures } \\
\text { (i.e., to service asset-related debts), and therefore excludes a small portion of the amount appropriated } \\
\text { each year by the Legislature. Also, the table does not include expenditures from funds carried forward } \\
\text { from previous vears. }\end{array}$} \\
\hline
\end{tabular}

Section 1 - Financial Resources (continued)

\begin{tabular}{|c|c|c|c|c|c|}
\hline & $\begin{array}{c}2006-07 \\
\text { Actual }\end{array}$ & $\begin{array}{c}\text { 2007-08 } \\
\text { Actual }\end{array}$ & $\begin{array}{c}\text { 2008-09 } \\
\text { Actual }\end{array}$ & $\begin{array}{c}\text { 2009-10 } \\
\text { Actual }\end{array}$ & $\begin{array}{c}2010-11 \\
\text { Estimates }\end{array}$ \\
\hline \multicolumn{6}{|c|}{ Appropriated Funding per FTE } \\
\hline General Revenue per FTE & $\$ 8,375$ & $\$ 7,276$ & $\$ 6,493$ & $\$ 5,424$ & $\$ 5,696$ \\
\hline Lottery Funds per FTE & $\$ 694$ & $\$ 601$ & $\$ 775$ & $\$ 670$ & $\$ 765$ \\
\hline Tuition \& Fees per FTE & $\$ 3,298$ & $\$ 3,064$ & $\$ 3,214$ & $\$ 3,628$ & $\$ 3,748$ \\
\hline Other Trust Funds per FTE & $\$ 207$ & $\$ 191$ & $\$ 188$ & $\$ 653$ & $\$ 619$ \\
\hline Total per FTE & $\$ 12,574$ & $\$ 11,129$ & $\$ 10,670$ & $\$ 10,375$ & $\$ 10,722$ \\
\hline \multicolumn{6}{|l|}{ Actual Funding per FTE } \\
\hline Tuition \& Fees per FTE & $\$ 3,116$ & $\$ 2,980$ & $\$ 3,069$ & $\$ 3,257$ & $\$ 3,471$ \\
\hline Total per FTE & $\$ 12,392$ & $\$ 11,048$ & $\$ 10,525$ & $\$ 10,004$ & $\$ 10,552$ \\
\hline \multicolumn{6}{|c|}{$\begin{array}{l}\text { Notes: (1) FTE is based on actual FTE, not funded FTE; (2) does not include Health-Science Center funds } \\
\text { or FTE; (3) FTE for these metrics uses the standard IPEDS definition of FTE, equal to } 30 \text { credit hours for } \\
\text { undergraduates and } 24 \text { for graduates; and (4) actual funding per student is based on actual tuition and } \\
\text { E\&G fees (does not include local fees) collected. }\end{array}$} \\
\hline
\end{tabular}

\begin{tabular}{|c|c|c|c|c|c|}
\hline & $\begin{array}{c}\text { 2006-07 } \\
\text { Actual }\end{array}$ & $\begin{array}{c}\text { 2007-08 } \\
\text { Actual }\end{array}$ & $\begin{array}{c}\text { 2008-09 } \\
\text { Actual }\end{array}$ & $\begin{array}{c}2009-10 \\
\text { Actual }\end{array}$ & $\begin{array}{c}2010-11 \\
\text { Estimates }\end{array}$ \\
\hline \multicolumn{6}{|c|}{ Auxiliary Enterprises } \\
\hline Revenues & $\$ 147,145,183$ & $\$ 163,094,763$ & $\$ 171,361,009$ & $\$ 142,802,349$ & $\$ 146,719,214$ \\
\hline Expenditures & $\$ 142,263,107$ & $\$ 150,015,206$ & $\$ 240,123,445$ & $\$ 115,485,207$ & $\$ 148,674,187$ \\
\hline \multicolumn{6}{|c|}{ Contracts \& Grants } \\
\hline Revenues & $\$ 291,385,057$ & $\$ 260,378,731$ & $\$ 346,300,000$ & $\$ 296,910,481$ & $\$ 378,309,848$ \\
\hline Expenditures & $\$ 323,846,060$ & $\$ 293,512,444$ & $\$ 340,000,000$ & $\$ 300,467,449$ & $\$ 383,310,048$ \\
\hline \multicolumn{6}{|l|}{ Local Funds } \\
\hline Revenues & $\$ 128,697,633$ & $\$ 145,745,675$ & $\$ 135,058,791$ & $\$ 408,521,266$ & $\$ 456,744,166$ \\
\hline Expenditures & $\$ 133,408,793$ & $\$ 133,879,634$ & $\$ 153,572,417$ & $\$ 406,432,437$ & $\$ 463,486,095$ \\
\hline
\end{tabular}

\begin{tabular}{|c|c|c|c|c|c|}
\hline & $\begin{array}{c}2006-07 \\
\text { Actual }\end{array}$ & $\begin{array}{c}2007-08 \\
\text { Actual }\end{array}$ & $\begin{array}{c}\text { 2008-09 } \\
\text { Actual }\end{array}$ & $\begin{array}{c}\text { 2009-10 } \\
\text { Actual }\end{array}$ & $\begin{array}{c}2010-11 \\
\text { Estimates }\end{array}$ \\
\hline $\begin{array}{c}\text { Total } \\
\text { Revenues }\end{array}$ & $\$ 1,002,470,851$ & $\$ 990,313,292$ & $\$ 1,060,233,185$ & $\$ 1,247,871,387$ & $\$ 1,412,800,591$ \\
\hline $\begin{array}{c}\text { Total } \\
\text { Expenditures }\end{array}$ & \$ 952,786,156 & $\$ 932,099,455$ & $\$ 1,069,860,069$ & $\$ 1,169,044,997$ & $\$ 1,436,129,985$ \\
\hline
\end{tabular}


Section 1 - Financial Resources (continued)

\begin{tabular}{|c|c|c|c|c|c|}
\hline TABLE 1F. Voluntary Support of Higher Education \\
\hline & $\mathbf{2 0 0 4 - 0 5}$ & $\mathbf{2 0 0 5 - 0 6}$ & $\mathbf{2 0 0 6 - 0 7}$ & $\mathbf{2 0 0 7 - 0 8}$ & $\mathbf{2 0 0 8 - 0 9}$ \\
\hline $\begin{array}{c}\text { Endowment Market } \\
\text { Value (Thousand \$) }\end{array}$ & $\$ 298,241$ & $\$ 329,832$ & $\$ 388,516$ & $\$ 360,035$ & $\$ 275,398$ \\
\hline $\begin{array}{c}\text { Annual Gifts } \\
\text { Received (\$) }\end{array}$ & $\$ 22,733,927$ & $\$ 46,346,593$ & $\$ 56,826,407$ & $\$ 44,682,695$ & $\$ 34,010,969$ \\
\hline $\begin{array}{c}\text { Percentage of } \\
\text { Graduates Who are } \\
\text { Alumni Donors }\end{array}$ & $5.9 \%$ & $5.6 \%$ & $4.8 \%$ & $8.2 \%$ & $8 \%$ \\
\hline
\end{tabular}

\begin{tabular}{|l|c|c|}
\hline TABLE 1G. University Federal Stimulus Dollars (ARRA) \\
\hline $\begin{array}{c}\mathbf{2 0 0 9 - 1 0} \\
\text { Actual }\end{array}$ & $\begin{array}{c}\mathbf{2 0 1 0 - 1 1} \\
\text { Estimates }\end{array}$ \\
\hline Jobs Saved/Created & $\$ 23,360,035$ & $\$ 22,331,948$ \\
\hline Scholarships & $\$ 0$ & $\$ 0$ \\
\hline Library Resources & $\$ 0$ & $\$ 0$ \\
\hline Building Repairs/Alterations & $\$ 0$ & $\$ 0$ \\
\hline Motor Vehicles & $\$ 0$ & $\$ 0$ \\
\hline Printing & $\$ 0$ & $\$ 0$ \\
\hline Furniture \& Equipment & $\$ 0$ & $\$ 0$ \\
\hline Information Technology Equipment & $\$ 0$ & $\$ 0$ \\
\hline Financial Aid to Medical Students & $\$ 0$ & $\$ 0$ \\
\hline Other & $\$ 0$ & $\$ 0$ \\
\hline
\end{tabular}

Section 1 - Financial Resources

\begin{tabular}{|c|c|c|c|c|c|}
\hline & $\begin{array}{r}2006-07 \\
\text { Actual }\end{array}$ & $\begin{array}{c}\text { 2007-08 } \\
\text { Actual }\end{array}$ & $\begin{array}{c}2008-09 \\
\text { Actual }\end{array}$ & $\begin{array}{r}2009-10 \\
\text { Actual } \\
\end{array}$ & $\begin{array}{c}2010-11 \\
\text { Estimates }\end{array}$ \\
\hline $\begin{array}{l}\text { Recurring } \\
\text { State Funds } \\
\text { (GR \& Lottery) }\end{array}$ & $\$ 65,740,706$ & $\$ 65,814,423$ & $\$ 62,041,950$ & $\$ 61,549,150$ & $\$ 61,564,883$ \\
\hline $\begin{array}{l}\text { Non-Recurring } \\
\text { State Funds } \\
\text { (GR \& Lottery) }\end{array}$ & $\$ 1,002,981$ & $\$ 1,626,101$ & $\$ 635,338$ & $\$ 0$ & $\$ 1,000,000$ \\
\hline $\begin{array}{l}\text { Tuition } \\
\text { (Resident \& Non-Resident) }\end{array}$ & $\$ 17,974,839$ & $\$ 22,648,230$ & $\$ 26,347,362$ & $\$ 29,988,216$ & $\$ 29,939,082$ \\
\hline Tuition Differential Fee & $\$ 0$ & $\$ 0$ & $\$ 111,799$ & $\$ 501,511$ & $\$ 995,431$ \\
\hline $\begin{array}{l}\text { Other Revenues } \\
\text { (Includes Misc. Fees \& Fines) }\end{array}$ & $\$ 4,678,832$ & $\$ 0$ & $\$ 0$ & $\$ 1,331$ & $\$ 0$ \\
\hline $\begin{array}{l}\text { Other Operating } \\
\text { Trust Funds }\end{array}$ & $\$ 0$ & $\$ 0$ & $\$ 0$ & $\$ 0$ & $\$ 0$ \\
\hline Federal Stimulus Funds & $\$ 0$ & $\$ 0$ & $\$ 0$ & $\$ 4,569,090$ & $\$ 4,351,772$ \\
\hline TOTAL & $\$ 89,397,358$ & $\$ 89,392,454$ & $\$ 89,136,449$ & $\$ 96,609,298$ & $\$ 97,851,168$ \\
\hline
\end{tabular}

\begin{tabular}{|c|c|c|c|c|c|}
\hline & $\begin{array}{l}\text { 2006-07 } \\
\text { Actual }\end{array}$ & $\begin{array}{l}\text { 2007-08 } \\
\text { Actual }\end{array}$ & $\begin{array}{l}\text { 2008-09 } \\
\text { Actual }\end{array}$ & $\begin{array}{c}\text { 2009-10 } \\
\text { Actual }\end{array}$ & $\begin{array}{c}\text { 2010-11 } \\
\text { Estimates }\end{array}$ \\
\hline Instruction/Research & $\$ 63,448,633$ & $\$ 64,625,114$ & $\$ 64,047,565$ & $\$ 68,082,738$ & $\$ 94,395,248$ \\
\hline $\begin{array}{l}\text { Institutes and Research } \\
\text { Centers }\end{array}$ & $\$ 202,840$ & $\$ 154,396$ & $\$ 1,153$ & $\$ 0$ & $\$ 0$ \\
\hline PO\&M & $\$ 90,778$ & $\$ 64,095$ & $\$ 262,695$ & $\$ 84,684$ & $\$ 1,992,534$ \\
\hline $\begin{array}{l}\text { Administration and } \\
\text { Support Services }\end{array}$ & $\$ 4,797,748$ & $\$ 5,200,070$ & $\$ 4,463,186$ & $\$ 5,033,768$ & $\$ 6,763,572$ \\
\hline Radio/TV & $\$ 0$ & $\$ 0$ & $\$ 0$ & $\$ 0$ & $\$ 0$ \\
\hline Library/Audio Visual & $\$ 3,008,725$ & $\$ 2,903,725$ & $\$ 2,787,282$ & $\$ 2,473,154$ & $\$ 2,464,944$ \\
\hline Museums and Galleries & $\$ 0$ & $\$ 0$ & $\$ 0$ & $\$ 0$ & $\$ 0$ \\
\hline Agricultural Extension & $\$ 0$ & $\$ 0$ & $\$ 0$ & $\$ 0$ & $\$ 0$ \\
\hline Student Services & $\$ 0$ & $\$ 0$ & $\$ 0$ & $\$ 0$ & $\$ 0$ \\
\hline Intercollegiate Athletics & $\$ 0$ & $\$ 0$ & $\$ 0$ & $\$ 0$ & $\$ 0$ \\
\hline TOTAL & $\$ 71,548,724$ & $\$ 72,947,400$ & $\$ 71,561,881$ & $\$ 75,674,344$ & $\$ 105,616,298$ \\
\hline \multicolumn{6}{|c|}{$\begin{array}{l}\text { The table reports the actual and estimated amount of expenditures from revenues appropriated by the } \\
\text { Legislature for each fiscal year. The expenditures are classified by Program Component (i.e., } \\
\text { Instruction/ Research, PO\&M, Administration, etc.) for activities directly related to instruction, research } \\
\text { and public service. The table does not include expenditures classified as non-operating expenditures } \\
\text { (i.e., to service asset-related debts), and therefore excludes a small portion of the amount appropriated } \\
\text { each year by the Legislature. Also, the table does not include expenditures from funds carried forward } \\
\text { from previous years. }\end{array}$} \\
\hline
\end{tabular}




\section{Section 1 - Financial Resources (continued)}

\begin{tabular}{|c|c|c|c|c|c|}
\hline & $\begin{array}{r}\text { 2006-07 } \\
\text { Actual } \\
\end{array}$ & $\begin{array}{c}2007-08 \\
\text { Actual }\end{array}$ & $\begin{array}{c}2008-09 \\
\text { Actual } \\
\end{array}$ & $\begin{array}{c}\text { 2009-10 } \\
\text { Actual } \\
\end{array}$ & $\begin{array}{c}2010-11 \\
\text { Estimates }\end{array}$ \\
\hline \multicolumn{6}{|c|}{ Auxiliary Enterprises } \\
\hline Revenues & $\$ 0$ & $\$ 0$ & $\$ 0$ & $\$ 0$ & $\$ 0$ \\
\hline Expenditures & $\$ 0$ & $\$ 0$ & $\$ 0$ & $\$ 0$ & $\$ 0$ \\
\hline \multicolumn{6}{|c|}{ Contracts \& Grants } \\
\hline Revenues & $\$ 0$ & $\$ 0$ & $\$ 0$ & $\$ 0$ & $\$ 0$ \\
\hline Expenditures & $\$ 0$ & $\$ 0$ & $\$ 0$ & $\$ 0$ & $\$ 0$ \\
\hline \multicolumn{6}{|l|}{ Local Funds } \\
\hline Revenues & $\$ 0$ & $\$ 0$ & $\$ 0$ & $\$ 0$ & $\$ 0$ \\
\hline Expenditures & $\$ 0$ & $\$ 0$ & $\$ 0$ & $\$ 0$ & $\$ 0$ \\
\hline \multicolumn{6}{|c|}{$\begin{array}{l}\text { Notes: Revenues do not include transfers. Expenditures do not include non-operating expenditures. All } \\
\text { Contracts \& Grants activities (for E\&G, Health-Science Centers and IFAS) are managed and reported by } \\
\text { each institution's Division of Sponsored Research, and are all reported in the University Other Budget } \\
\text { Entities table. }\end{array}$} \\
\hline
\end{tabular}

\begin{tabular}{|c|c|c|c|c|c|}
\hline \multicolumn{7}{|c|}{ TABLE 1E. Health-Science Center Total Revenues and Expenditures } \\
\hline & $\begin{array}{c}\mathbf{2 0 0 6 - 0 7} \\
\text { Actual }\end{array}$ & $\begin{array}{c}\mathbf{2 0 0 7 - 0 8} \\
\text { Actual }\end{array}$ & $\begin{array}{c}\mathbf{2 0 0 8 - 0 9} \\
\text { Actual }\end{array}$ & $\begin{array}{c}\mathbf{2 0 0 9 - 1 0} \\
\text { Actual }\end{array}$ & $\begin{array}{c}\mathbf{2 0 1 0 - 1 1} \\
\text { Estimates }\end{array}$ \\
\hline $\begin{array}{c}\text { Total } \\
\text { Revenues }\end{array}$ & $\$ 89,397,358$ & $\$ 89,392,454$ & $\$ 89,136,449$ & $\$ 96,609,298$ & $\$ 97,851,168$ \\
\hline $\begin{array}{c}\text { Total } \\
\text { Expenditures }\end{array}$ & $\$ 71,548,724$ & $\$ 72,947,400$ & $\$ 71,561,881$ & $\$ 75,674,344$ & $\$ 105,616,298$ \\
\hline
\end{tabular}

\section{Section 2 - Personnel}

\begin{tabular}{|c|c|c|c|c|c|c|c|c|c|c|c|}
\hline \multicolumn{1}{|c|}{ TABLE 2A. Personnel Headcount } \\
\hline & $\begin{array}{c}\text { Full- } \\
\text { Time }\end{array}$ & $\begin{array}{c}\text { Part- } \\
\text { Time }\end{array}$ & $\begin{array}{c}\text { Full- } \\
\text { Time }\end{array}$ & $\begin{array}{c}\text { Part- } \\
\text { Time }\end{array}$ & $\begin{array}{c}\text { Full- } \\
\text { Time }\end{array}$ & $\begin{array}{c}\text { Part- } \\
\text { Time }\end{array}$ & $\begin{array}{c}\text { Full- } \\
\text { Time }\end{array}$ & $\begin{array}{c}\text { Part- } \\
\text { Time }\end{array}$ & $\begin{array}{c}\text { Full- } \\
\text { Time }\end{array}$ & $\begin{array}{c}\text { Part- } \\
\text { Time }\end{array}$ \\
\hline $\begin{array}{c}\text { Total Tenure/ } \\
\text { Tenure-track } \\
\text { Faculty }\end{array}$ & 1,204 & 87 & 1,210 & 77 & 1,175 & 78 & 1,103 & 80 & 1,115 & 79 \\
\hline $\begin{array}{c}\text { Total Non- } \\
\text { Tenure Track } \\
\text { Faculty }\end{array}$ & 488 & 156 & 543 & 165 & 582 & 170 & 476 & 154 & 503 & 241 \\
\hline $\begin{array}{c}\text { Instructors } \\
\text { Without Faculty } \\
\text { Status }\end{array}$ & 0 & 0 & 0 & 0 & 0 & 0 & 0 & 0 & 0 & 0 \\
\hline $\begin{array}{c}\text { Total Graduate } \\
\text { Assistants/ } \\
\text { Associates }\end{array}$ & 0 & 1,692 & 0 & 1,752 & 0 & 1,725 & 0 & 1,774 & 0 & 1,866 \\
\hline $\begin{array}{c}\text { Total Executive/ } \\
\text { Administrative/ } \\
\text { Managerial }\end{array}$ & 504 & 12 & 528 & 16 & 603 & 19 & 606 & 15 & 634 & 17 \\
\hline $\begin{array}{c}\text { Total Other } \\
\text { Professional }\end{array}$ & 1,792 & 118 & 1,829 & 101 & 1,715 & 93 & 1,710 & 72 & 1,735 & 130 \\
\hline $\begin{array}{c}\text { Total Non- } \\
\text { Professional }\end{array}$ & 1,640 & 30 & 1,686 & 31 & 1,792 & 41 & 1,731 & 40 & 1,721 & 245 \\
\hline
\end{tabular}




\section{Section 3 - Enrollment}

\section{TABLE 3A. University Full-Time Enrollment (FTE)}

2008-09 $2009-10$

2010-11

\begin{tabular}{l|l|l|l|l|l|} 
Funded & Actual & Funded & Actual & Funded & Estimated
\end{tabular}

FLORIDA RESIDENTS

\begin{tabular}{|l|c|c|c|c|c|c|}
\hline Lower & 9,378 & 8,979 & 9,378 & 9,182 & 9,378 & 9,275 \\
\hline Upper & 13,361 & 13,848 & 13,361 & 14,384 & 13,361 & 14,807 \\
\hline Grad I & 3,680 & 4,002 & 3,680 & 4,020 & 3,680 & 4,044 \\
\hline Grad II & 854 & 859 & 854 & 909 & 854 & 959 \\
\hline Total & 27,273 & 27,687 & 27,273 & 28,495 & 27,273 & 29,085 \\
\hline NON-FLORIDA RESIDENTS
\end{tabular}

\section{NON-FLORIDA RESIDENTS}

\begin{tabular}{|l|c|c|c|c|c|c|}
\hline Lower & & 330 & & 338 & & 351 \\
\hline Upper & & 415 & & 408 & & 423 \\
\hline Grad I & & 374 & & 461 & & 445 \\
\hline Grad II & & 232 & & 258 & & 263 \\
\hline Total & 1,400 & 1,351 & 1,400 & 1,465 & 1,400 & 1,483 \\
\hline \multicolumn{7}{|l|}{} \\
\hline $\begin{array}{l}\text { TOTAL FTE } \\
\text { Lower }\end{array}$ & 9,309 & & 9,520 & & 9,626 \\
\hline Upper & 14,263 & & 14,792 & & 15,230 \\
\hline Grad I & 4,376 & & 4,481 & & 4,489 \\
\hline Grad II & 1,091 & & 1,167 & & 1,222 \\
\hline $\begin{array}{l}\text { Total FTE } \\
\text { (FL Definition) }\end{array}$ & 28,673 & 29,038 & 28,673 & 29,960 & 28,673 & 30,567 \\
\hline $\begin{array}{l}\text { Total FTE } \\
\text { (US Definition) }\end{array}$ & 38,231 & 38,718 & 38,231 & 39,947 & 38,231 & 40,756 \\
\hline
\end{tabular}

\section{Headcount for Medical Doctorates}

\begin{tabular}{l|c|c|c|c|c|c}
$\begin{array}{l}\text { Florida } \\
\text { Residents }\end{array}$ & 480 & 465 & 480 & 460 & 480 & 460 \\
\hline Non-Residents & 0 & 17 & 0 & 22 & 0 & 22 \\
\hline Total & 480 & 482 & 480 & 482 & 480 & 482 \\
\hline
\end{tabular}

Notes: Florida definitions of FTE (Undergraduate FTE $=40$ and Graduate FTE $=32$ credit hours per FTE) are used for all items except the row named Total FTE (US Definition), which is based on an

Undergraduate FTE $=30$ and Graduate FTE $=24$ credit hours. Actual Medical headcounts (includes

Medicine, Dentistry, and Veterinary programs) are based on Fall enrollment data.
Section 3 - Enrollment (continued)

\begin{tabular}{|c|c|c|c|}
\hline & $\begin{array}{r}2008-09 \\
\text { Actual } \\
\end{array}$ & $\begin{array}{c}\text { 2009-10 } \\
\text { Actual }\end{array}$ & $\begin{array}{c}2010-11 \\
\text { Estimated }\end{array}$ \\
\hline \multicolumn{4}{|l|}{ TAMPA } \\
\hline Lower & 8,230 & 8,230 & 8,409 \\
\hline Upper & 10,202 & 10,551 & 10,878 \\
\hline Grad I & 2,793 & 2,817 & 2,983 \\
\hline Grad II & 878 & 904 & 1,002 \\
\hline \multicolumn{4}{|l|}{ HEALTH } \\
\hline Lower & 316 & 349 & 319 \\
\hline Upper & 844 & 875 & 854 \\
\hline Grad I & 978 & 1,045 & 985 \\
\hline Grad II & 209 & 206 & 220 \\
\hline \multicolumn{4}{|l|}{ ST. PETERSBURG } \\
\hline Lower & 741 & 849 & 845 \\
\hline Upper & 1,547 & 1,649 & 1,648 \\
\hline Grad I & 296 & 280 & 266 \\
\hline Grad II & 1 & 30 & 0 \\
\hline \multicolumn{4}{|c|}{ SARASOTA BRANCH } \\
\hline Lower & 7 & 56 & 0 \\
\hline Upper & 922 & 1,007 & 1,080 \\
\hline Grad I & 184 & 167 & 135 \\
\hline Grad II & 2 & 1 & 0 \\
\hline \multicolumn{4}{|l|}{ POLYTECHNIC } \\
\hline Lower & 22 & 32 & 53 \\
\hline Upper & 757 & 707 & 770 \\
\hline Grad I & 133 & 105 & 120 \\
\hline Grad II & 1 & 0 & 0 \\
\hline
\end{tabular}


Section 4 - Undergraduate Education

\begin{tabular}{|c|c|c|c|c|c|}
\hline Title of Program & $\begin{array}{l}\text { Six-digit } \\
\text { CIP } \\
\text { Code }\end{array}$ & $\begin{array}{l}\text { Degree } \\
\text { Level }\end{array}$ & $\begin{array}{l}\text { Date of } \\
\text { UBOT } \\
\text { Action }\end{array}$ & $\begin{array}{c}\text { Starting } \\
\text { or Ending } \\
\text { Term }\end{array}$ & Comments \\
\hline \multicolumn{6}{|l|}{ New Programs } \\
\hline Advertising & 52.1499 & Bachelor's & $12 / 03 / 2009$ & FALL 2009 & \\
\hline \multicolumn{6}{|l|}{ Terminated Programs } \\
\hline \multicolumn{6}{|l|}{ Suspended Programs } \\
\hline \multirow{2}{*}{\multicolumn{6}{|c|}{ New Programs Considered By University But Not Approved }} \\
\hline & & & & & \\
\hline \multicolumn{6}{|c|}{$\begin{array}{l}\text { Note: This table does not include new majors or concentrations added under an existing degree program } \\
\text { CIP Code. This table reports the program changes between May 5, } 2009 \text { and May 4, 2010. New } \\
\text { Programs are proposed new degree programs that have been completely through the approval process } \\
\text { at the university, and if appropriate, the Board of Governors. Terminated Programs are degree } \\
\text { programs for which the entire CIP Code has been terminated and removed from the university's } \\
\text { inventory of degree programs. Suspended Programs are degree programs for which enrollments have } \\
\text { been temporarily suspended for the entire CIP Code, but the program CIP Code has not been } \\
\text { terminated. }\end{array}$} \\
\hline
\end{tabular}

\begin{tabular}{|}
\begin{tabular}{|c|c|c|c|c|c|}
\hline TABLE 4B. First-Year Persistence Rates \\
\hline $\begin{array}{c}\text { Term of Entry } \\
\begin{array}{c}\text { Cohort Size } \\
\text { Full-time FTIC }\end{array}\end{array}$ Fall 2004 & Fall 2005 & Fall 2006 & Fall 2007 & Fall 2008 \\
\hline From Same University & 4,568 & 4,349 & 4,399 & 4,143 & 4,395 \\
\hline \% Still Enrolled & $84.3 \%$ & $82.5 \%$ & $83.6 \%$ & $87.3 \%$ & $87.2 \%$ \\
\hline
\end{tabular}
\end{tabular}

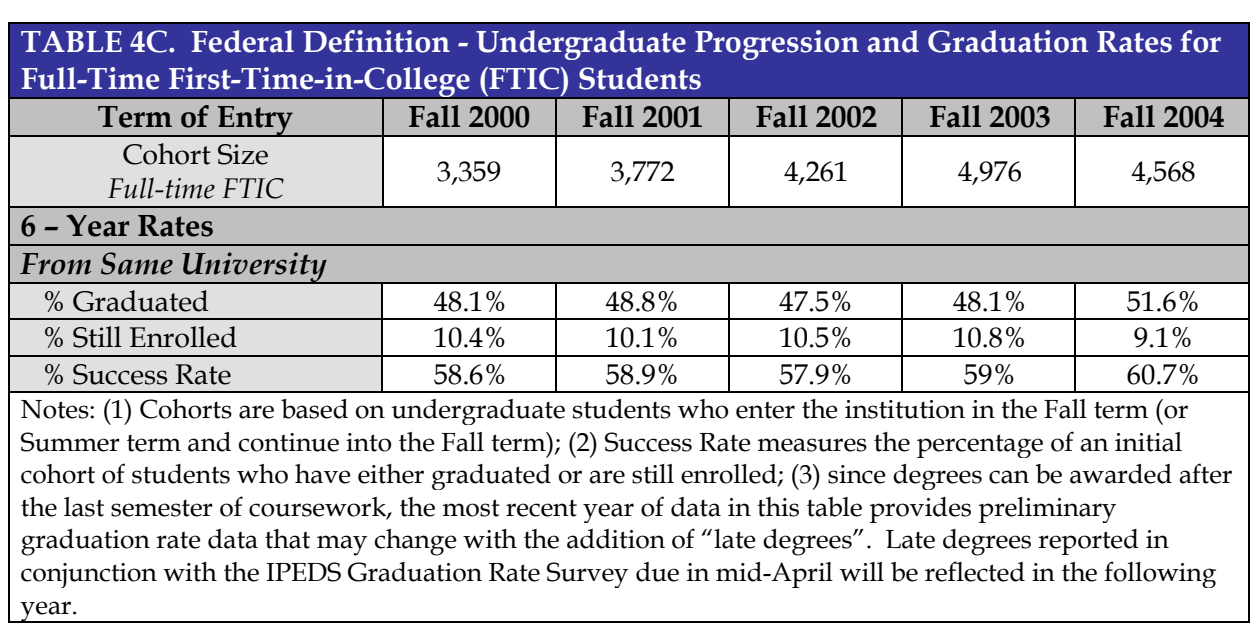

Section 4 - Undergraduate Education (continued)

\begin{tabular}{|c|c|c|c|c|c|}
\hline Term of Entry & Fall 2000 & Fall 2001 & Fall 2002 & Fall 2003 & Fall 2004 \\
\hline $\begin{array}{c}\text { Cohort Size } \\
\text { Full- E Part-time }\end{array}$ & 3,919 & 4,498 & 4,488 & 5,212 & 4,753 \\
\hline \multicolumn{6}{|l|}{4 - Year Rates } \\
\hline \multicolumn{6}{|l|}{ From Same University } \\
\hline$\%$ Graduated & $19.4 \%$ & $18.4 \%$ & $20.2 \%$ & $20.2 \%$ & $22.8 \%$ \\
\hline \% Still Enrolled & $43.1 \%$ & $44.9 \%$ & $41.9 \%$ & $42.4 \%$ & $42.5 \%$ \\
\hline \multicolumn{6}{|c|}{ From Other SUS University } \\
\hline$\%$ Graduated & $1.9 \%$ & $1.2 \%$ & $1.3 \%$ & $1.5 \%$ & $1.5 \%$ \\
\hline \% Still Enrolled & $4.6 \%$ & $3.8 \%$ & $3.8 \%$ & $3.9 \%$ & $4.7 \%$ \\
\hline \multicolumn{6}{|c|}{ From State University System } \\
\hline$\%$ Graduated & $21.4 \%$ & $19.6 \%$ & $21.4 \%$ & $21.6 \%$ & $24.3 \%$ \\
\hline \% Still Enrolled & $47.7 \%$ & $48.7 \%$ & $45.7 \%$ & $46.3 \%$ & $47.2 \%$ \\
\hline$\%$ Success Rate & $69 \%$ & $68.3 \%$ & $67.1 \%$ & $67.9 \%$ & $71.5 \%$ \\
\hline \multicolumn{6}{|l|}{6 - Year Rates } \\
\hline \multicolumn{6}{|l|}{ From Same University } \\
\hline$\%$ Graduated & $46.3 \%$ & $46.3 \%$ & $46.4 \%$ & $46.9 \%$ & $50.7 \%$ \\
\hline \% Still Enrolled & $10.9 \%$ & $11.1 \%$ & $10.7 \%$ & $11 \%$ & $9.4 \%$ \\
\hline \multicolumn{6}{|c|}{ From Other SUS University } \\
\hline$\%$ Graduated & $4.6 \%$ & $3.8 \%$ & $4.1 \%$ & $4.3 \%$ & $3.8 \%$ \\
\hline \% Still Enrolled & $2 \%$ & $1.9 \%$ & $1.5 \%$ & $1.5 \%$ & $3.1 \%$ \\
\hline \multicolumn{6}{|c|}{ From State University System } \\
\hline$\%$ Graduated & $51 \%$ & $50.1 \%$ & $50.5 \%$ & $51.3 \%$ & $54.5 \%$ \\
\hline$\%$ Still Enrolled & $12.9 \%$ & $13 \%$ & $12.1 \%$ & $12.5 \%$ & $12.5 \%$ \\
\hline$\%$ Success Rate & $63.8 \%$ & $63.1 \%$ & $62.6 \%$ & $63.8 \%$ & $67 \%$ \\
\hline \multicolumn{6}{|c|}{$\begin{array}{l}\text { Notes: (1) Cohorts are based on undergraduate students who enter the institution in the Fall term (or } \\
\text { Summer term and continue into the Fall term); (2) Success Rate measures the percentage of an initial } \\
\text { cohort of students who have either graduated or are still enrolled; (3) since degrees can be awarded after } \\
\text { the last semester of coursework, the most recent year of data in this table provides preliminary } \\
\text { graduation rate data that may change with the addition of "late degrees". Late degrees reported in } \\
\text { conjunction with the IPEDS Graduation Rate Survey due in mid-April will be reflected in the following } \\
\text { year. }\end{array}$} \\
\hline
\end{tabular}

University of South Florida - Page 7 
Section 4 - Undergraduate Education (continued)

\begin{tabular}{|c|c|c|c|c|c|}
\hline Term of Entry & Fall 2002 & Fall 2003 & Fall 2004 & Fall 2005 & Fall 2006 \\
\hline $\begin{array}{c}\text { Cohort Size } \\
\text { Full- \& Part-time }\end{array}$ & 1,863 & 1,751 & 1,914 & 2,067 & 2,009 \\
\hline \multicolumn{6}{|l|}{2 - Year Rates } \\
\hline \multicolumn{6}{|l|}{ From Same University } \\
\hline$\%$ Graduated & $25.2 \%$ & $24.8 \%$ & $27.7 \%$ & $26.4 \%$ & $27.6 \%$ \\
\hline \% Still Enrolled & $57.5 \%$ & $60.1 \%$ & $57.5 \%$ & $58.9 \%$ & $58.5 \%$ \\
\hline \multicolumn{6}{|c|}{ From Other SUS University } \\
\hline$\%$ Graduated & $0.1 \%$ & $0.2 \%$ & $0.3 \%$ & $0.2 \%$ & $0.1 \%$ \\
\hline \% Still Enrolled & $1.6 \%$ & $1.1 \%$ & $2 \%$ & $1.8 \%$ & $1.5 \%$ \\
\hline \multicolumn{6}{|c|}{ From State University System } \\
\hline$\%$ Graduated & $25.3 \%$ & $25 \%$ & $28 \%$ & $26.6 \%$ & $27.7 \%$ \\
\hline \% Still Enrolled & $59.1 \%$ & $61.3 \%$ & $59.5 \%$ & $60.7 \%$ & $60 \%$ \\
\hline \% Success Rate & $84.4 \%$ & $86.2 \%$ & $87.5 \%$ & $87.3 \%$ & $87.7 \%$ \\
\hline \multicolumn{6}{|l|}{4 - Year Rates } \\
\hline \multicolumn{6}{|l|}{ From Same University } \\
\hline$\%$ Graduated & $60.5 \%$ & $62.1 \%$ & $64.6 \%$ & $62.8 \%$ & $63.7 \%$ \\
\hline \% Still Enrolled & $11.1 \%$ & $12.6 \%$ & $10.9 \%$ & $12.7 \%$ & $12.4 \%$ \\
\hline \multicolumn{6}{|c|}{ From Other SUS University } \\
\hline$\%$ Graduated & $1.4 \%$ & $1.1 \%$ & $1.4 \%$ & $1.4 \%$ & $0.7 \%$ \\
\hline \% Still Enrolled & $1.3 \%$ & $0.5 \%$ & $1.2 \%$ & $0.7 \%$ & $1.2 \%$ \\
\hline \multicolumn{6}{|c|}{ From State University System } \\
\hline$\%$ Graduated & $61.9 \%$ & $63.3 \%$ & $65.9 \%$ & $64.2 \%$ & $64.5 \%$ \\
\hline \% Still Enrolled & $12.3 \%$ & $13.1 \%$ & $12.1 \%$ & $13.4 \%$ & $13.6 \%$ \\
\hline \% Success Rate & $74.2 \%$ & $76.4 \%$ & $78.1 \%$ & $77.5 \%$ & $78 \%$ \\
\hline \multicolumn{6}{|c|}{$\begin{array}{l}\text { Notes: (1) Cohorts are based on undergraduate students who enter the institution in the Fall term (or } \\
\text { Summer term and continue into the Fall term); (2) Success Rate measures the percentage of an initial } \\
\text { cohort of students who have either graduated or are still enrolled; (3) since degrees can be awarded after } \\
\text { the last semester of coursework, the most recent year of data in this table provides preliminary } \\
\text { graduation rate data that may change with the addition of "late degrees". Late degrees reported in } \\
\text { conjunction with the IPEDS Graduation Rate Survey due in mid-April will be reflected in the following } \\
\text { year. }\end{array}$} \\
\hline
\end{tabular}

Section 4 - Undergraduate Education (continued)

\begin{tabular}{|c|c|c|c|c|c|}
\hline Term of Entry & Fall 2001 & Fall 2002 & Fall 2003 & Fall 2004 & Fall 2005 \\
\hline $\begin{array}{c}\text { Cohort Size } \\
\text { Full- E Part-time }\end{array}$ & 2,275 & 2,217 & 2,399 & 2,495 & 2,498 \\
\hline \multicolumn{6}{|l|}{5 - Year Rates } \\
\hline \multicolumn{6}{|l|}{ From Same University } \\
\hline$\%$ Graduated & $54.2 \%$ & $52.1 \%$ & $55.5 \%$ & $55.6 \%$ & $53.4 \%$ \\
\hline \% Still Enrolled & $6.9 \%$ & $7.8 \%$ & $7.1 \%$ & $6.7 \%$ & $6.5 \%$ \\
\hline \multicolumn{6}{|c|}{ From Other SUS University } \\
\hline$\%$ Graduated & $1.6 \%$ & $2.2 \%$ & $2 \%$ & $1.6 \%$ & $1.3 \%$ \\
\hline \% Still Enrolled & $0.4 \%$ & $0.7 \%$ & $0.7 \%$ & $0.8 \%$ & $0.8 \%$ \\
\hline \multicolumn{6}{|c|}{ From State University System } \\
\hline$\%$ Graduated & $55.8 \%$ & $54.3 \%$ & $57.5 \%$ & $57.2 \%$ & $54.7 \%$ \\
\hline \% Still Enrolled & $7.3 \%$ & $8.5 \%$ & $7.8 \%$ & $7.5 \%$ & $7.2 \%$ \\
\hline$\%$ Success Rate & $63.1 \%$ & $62.8 \%$ & $65.3 \%$ & $64.6 \%$ & $61.9 \%$ \\
\hline \multicolumn{6}{|c|}{$\begin{array}{l}\text { Notes: (1) Cohorts are based on undergraduate students who enter the institution in the Fall term (or } \\
\text { Summer term and continue into the Fall term); (2) Success Rate measures the percentage of an initial } \\
\text { cohort of students who have either graduated or are still enrolled; (3) since degrees can be awarded after } \\
\text { the last semester of coursework, the most recent year of data in this table provides preliminary } \\
\text { graduation rate data that may change with the addition of "late degrees". Late degrees reported in } \\
\text { conjunction with the IPEDS Graduation Rate Survey due in mid-April will be reflected in the following } \\
\text { year. }\end{array}$} \\
\hline
\end{tabular}

\begin{tabular}{|c|c|c|c|c|c|}
\hline TABLE 4G. Baccalaureate Degrees Awarded \\
\hline & $\mathbf{2 0 0 5 - 0 6}$ & $\mathbf{2 0 0 6 - 0 7}$ & $\mathbf{2 0 0 7 - 0 8}$ & $\mathbf{2 0 0 8 - 0 9}$ & $\mathbf{2 0 0 9 - 1 0}$ \\
\hline Baccalaureate Degrees & 6,129 & 6,736 & 7,086 & 7,479 & 7,891 \\
\hline
\end{tabular}

\begin{tabular}{|c|c|c|c|c|c|}
\hline \multicolumn{10}{|c|}{ TABLE 4H. Baccalaureate Degrees Awarded in Areas of Strategic Emphasis } \\
\hline & $\mathbf{2 0 0 5 - 0 6}$ & $\mathbf{2 0 0 6 - 0 7}$ & $\mathbf{2 0 0 7 - 0 8}$ & $\mathbf{2 0 0 8 - 0 9}$ & $\mathbf{2 0 0 9 - 1 0}$ \\
\hline Education & 97 & 94 & 105 & 112 & 105 \\
\hline Health Professions & 339 & 443 & 420 & 435 & 437 \\
\hline $\begin{array}{c}\text { Science, Technology, } \\
\text { Engineering, and Math }\end{array}$ & 1,127 & 1,255 & 1,299 & 1,395 & 1,536 \\
\hline $\begin{array}{c}\text { Security and Emergency } \\
\text { Services }\end{array}$ & 337 & 366 & 394 & 412 & 458 \\
\hline Globalization & 377 & 427 & 445 & 470 & 490 \\
\hline
\end{tabular}


Section 4 - Undergraduate Education (continued)

\begin{tabular}{|c|c|c|c|c|c|}
\hline & 2005-06 & 2006-07 & 2007-08 & $\begin{array}{c}2008-09 \\
\text { BASELINE YEAR }\end{array}$ & 2009-10 \\
\hline \multicolumn{6}{|l|}{ Non-Hispanic Black } \\
\hline $\begin{array}{c}\text { Number of Baccalaureate } \\
\text { Degrees }\end{array}$ & 683 & 774 & 811 & $\begin{array}{c}899 \\
\text { Increase* }\end{array}$ & 872 \\
\hline $\begin{array}{c}\text { Percentage of All } \\
\text { Baccalaureate Degrees }\end{array}$ & $11.7 \%$ & $12.1 \%$ & $12.0 \%$ & $\begin{array}{c}12.4 \% \\
\text { Increase* }\end{array}$ & $11.4 \%$ \\
\hline \multicolumn{6}{|l|}{ Hispanic } \\
\hline $\begin{array}{c}\text { Number of Baccalaureate } \\
\text { Degrees }\end{array}$ & 595 & 685 & 764 & $\begin{array}{c}875 \\
\text { Increase* }\end{array}$ & 941 \\
\hline $\begin{array}{c}\text { Percentage of All } \\
\text { Baccalaureate Degrees }\end{array}$ & $10.2 \%$ & $10.7 \%$ & $11.3 \%$ & $\begin{array}{c}12.1 \% \\
\text { Increase }^{*}\end{array}$ & $12.3 \%$ \\
\hline \multicolumn{6}{|l|}{ Pell-Grant Recipients } \\
\hline $\begin{array}{c}\text { Number of Baccalaureate } \\
\text { Degrees }\end{array}$ & 2,350 & 2,633 & 2,662 & $\begin{array}{c}2,853 \\
\text { Maintain* }\end{array}$ & 3,202 \\
\hline $\begin{array}{c}\text { Percentage of All } \\
\text { Baccalaureate Degrees }\end{array}$ & $39.7 \%$ & $40.2 \%$ & $38.4 \%$ & $\begin{array}{c}38.8 \% \\
\text { Maintain* }\end{array}$ & $41.1 \%$ \\
\hline \multicolumn{6}{|c|}{$\begin{array}{l}\text { Note: Pell-Grant recipients are defined as those students who have received a Pell grant from any SUS } \\
\text { Institution within six years of graduation. This does not include degrees awarded to students whose } \\
\text { race/ethnicity code is missing (or not reported) or for students who are non-resident aliens. } \\
\text { Note*: Directional goals for the 2012-13 year as reported in the } 2010 \text { University Workplan. }\end{array}$} \\
\hline
\end{tabular}

\begin{tabular}{|c|c|c|c|c|c|}
\hline TABLE 4J. Baccalaureate Completion Without Excess Credit Hours \\
\hline & $\mathbf{2 0 0 5 - 0 6}$ & $\mathbf{2 0 0 6 - 0 7}$ & $\mathbf{2 0 0 7 - 0 8}$ & $\mathbf{2 0 0 8 - 0 9}$ & $\mathbf{2 0 0 9 - 1 0}$ \\
\hline $\begin{array}{c}\text { \% of Total Baccalaureate } \\
\text { Degrees Awarded }\end{array}$ & $53.7 \%$ & $51.7 \%$ & $39.1 \%$ & $39.8 \%$ & $39.2 \%$ \\
$\begin{array}{c}\text { Within 110\% of Hours } \\
\text { Required for Degree }\end{array}$ & & & & \\
\hline
\end{tabular}

\begin{tabular}{|c|c|c|c|c|c|}
\hline & Fall 2005 & Fall 2006 & Fall 2007 & Fall 2008 & Fall 2009 \\
\hline $\begin{array}{c}\text { Number of } \\
\text { Course Sections }\end{array}$ & 3,050 & 3,118 & 3,275 & 3,023 & 3,157 \\
\hline \multicolumn{6}{|c|}{ Percentage of Undergraduate Course Sections by Class Size } \\
\hline Fewer than 30 Students & $57.2 \%$ & $58.7 \%$ & $60.5 \%$ & $56.7 \%$ & $58.8 \%$ \\
\hline 30 to 49 Students & $28.2 \%$ & $27.7 \%$ & $26.5 \%$ & $28.0 \%$ & $27.5 \%$ \\
\hline 50 to 99 Students & $11.1 \%$ & $10.3 \%$ & $9.8 \%$ & $12.1 \%$ & $10.7 \%$ \\
\hline 100 or More Students & $3.5 \%$ & $3.3 \%$ & $3.2 \%$ & $3.2 \%$ & $3 \%$ \\
\hline
\end{tabular}

Section 4 - Undergraduate Education (continued)

\begin{tabular}{|c|c|c|c|c|c|}
\hline$x^{2}+x^{2}$ & $2005-06$ & 2006-07 & 2007-08 & 2008-09 & 2009-10 \\
\hline \multicolumn{6}{|c|}{ Percentage of Credit Hours Taught by: } \\
\hline Faculty & $60.5 \%$ & $60.3 \%$ & $61.4 \%$ & $62.5 \%$ & $65.1 \%$ \\
\hline Adjunct Faculty & $24.7 \%$ & $23.7 \%$ & $23.9 \%$ & $23.3 \%$ & $21.2 \%$ \\
\hline Graduate Students & $14.4 \%$ & $15.5 \%$ & $14.2 \%$ & $13.8 \%$ & $13.0 \%$ \\
\hline Other Instructors & $0.4 \%$ & $0.5 \%$ & $0.4 \%$ & $0.4 \%$ & $0.8 \%$ \\
\hline
\end{tabular}

\begin{tabular}{|c|c|c|c|c|c|}
\hline 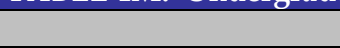 & 2005-06 & 2006-07 & 2007-08 & 2008-09 & 2009-10 \\
\hline $\begin{array}{c}\text { Average Salary and } \\
\text { Benefits for Faculty } \\
\text { Who Teach at Least One } \\
\text { Undergraduate Course }\end{array}$ & $\$ 85,689$ & $\$ 90,111$ & $\$ 93,079$ & $\$ 89,791$ & $\$ 93,039$ \\
\hline
\end{tabular}

\begin{tabular}{l}
\hline TABLE 4N. Student/Faculty Ratio \\
\begin{tabular}{|c|c|c|c|c|c|}
\hline \multicolumn{7}{|c|}{} & $\mathbf{2 0 0 5 - 0 6}$ & $\mathbf{2 0 0 6 - 0 7}$ & $\mathbf{2 0 0 7 - 0 8}$ & $\mathbf{2 0 0 8 - 0 9}$ & $\mathbf{2 0 0 9 - 1 0}$ \\
\hline Student-to-Faculty Ratio & 24.7 & 25.8 & 26.8 & 27.1 & 27.3 \\
\hline
\end{tabular} \\
$\begin{array}{l}\text { Note: The definition of faculty varies for Tables 4L, 4M and 4N. For Student/Faculty Ratio, the } \\
\text { definition of faculty is consistent with Common Data Set reporting (which counts full-time equivalent } \\
\text { instructional faculty as full-time faculty plus 1/3 part-time faculty). }\end{array}$ \\
\hline
\end{tabular}

\begin{tabular}{|c|c|c|c|c|c|}
\hline & 2005-06 & 2006-07 & 2007-08 & 2008-09 & 2009-10 \\
\hline \multicolumn{6}{|c|}{ Nursing: National Council Licensure Examination for Registered Nurses } \\
\hline Examinees & 121 & 95 & 152 & 157 & 151 \\
\hline Pass Rate & $95.9 \%$ & $82.1 \%$ & $92.1 \%$ & $98.1 \%$ & $96 \%$ \\
\hline National Benchmark & $86.7 \%$ & $88.3 \%$ & $86.4 \%$ & $87.5 \%$ & $89.5 \%$ \\
\hline
\end{tabular}




\section{Section 4 - Undergraduate Education (continued)}

\begin{tabular}{|c|c|c|c|}
\hline TABLE 4P. Tuition Differential Fee & $\mathbf{2 0 0 8 - 0 9}$ & $\mathbf{2 0 0 9 - 1 0}$ & $\begin{array}{c}\mathbf{2 0 1 0 - 1 1} \\
\text { Projected }\end{array}$ \\
\hline $\begin{array}{c}\text { Total Revenues Generated By the Tuition } \\
\text { Differential }\end{array}$ & $\$ 2,626,024$ & $\$ 7,458,495$ & $\$ 14,135,844$ \\
\hline $\begin{array}{c}\text { Unduplicated Count of Students } \\
\text { Receiving Financial Aid Award Funded by } \\
\text { Tuition Differential Revenues }\end{array}$ & 0 & 2,171 & \\
\hline $\begin{array}{c}\text { Average Amount of Awards Funded by } \\
\text { Tuition Differential Revenues (per student } \\
\text { receiving an award) }\end{array}$ & 0 & 1,043 & \\
\hline $\begin{array}{c}\text { Number of Students Eligible for FSAG } \\
\text { Number of FSAG-Eligible Students } \\
\text { Receiving a Waiver of the Tuition } \\
\text { Differential }\end{array}$ & 6,646 & 7,102 & \\
\hline $\begin{array}{c}\text { Value of Tuition Differential Waivers } \\
\text { Provided to FSAG-Eligible Students }\end{array}$ & 0 & 0 & \\
\hline
\end{tabular}

\section{Section 5 - Graduate Education}

\begin{tabular}{|c|c|c|c|c|c|c|}
\hline Title of Program & $\begin{array}{c}\text { Six-digit } \\
\text { CIP } \\
\text { Code }\end{array}$ & $\begin{array}{l}\text { Degree } \\
\text { Level }\end{array}$ & $\begin{array}{l}\text { Date of } \\
\text { UBOT } \\
\text { Action }\end{array}$ & $\begin{array}{l}\text { Starting } \\
\text { or Ending } \\
\text { Term }\end{array}$ & $\begin{array}{l}\text { Date of } \\
\text { Board of } \\
\text { Governors } \\
\text { Action }\end{array}$ & Comments \\
\hline \multicolumn{7}{|l|}{ New Programs } \\
\hline Global Sustainability & 30.3301 & Master's & $12 / 03 / 2009$ & $\begin{array}{c}\text { SUMMER } \\
2010\end{array}$ & & \\
\hline Economics & 45.0601 & $\begin{array}{l}\text { Research } \\
\text { Doctorate }\end{array}$ & $12 / 03 / 2009$ & FALL 2010 & $6 / 18 / 2010$ & \\
\hline \multicolumn{7}{|l|}{ Terminated Programs } \\
\hline \multicolumn{7}{|l|}{ Suspended Programs } \\
\hline \multicolumn{7}{|c|}{ New Programs Considered By University But Not Approved } \\
\hline \multicolumn{7}{|c|}{$\begin{array}{l}\text { Note: This table does not include new majors or concentrations added under an existing degree program } \\
\text { CIP Code. This table reports the program changes between May 5, } 2009 \text { and May } 4,2010 \text {. New } \\
\text { Programs are proposed new degree programs that have been completely through the approval process } \\
\text { at the university, and if appropriate, the Board of Governors. Terminated Programs are degree } \\
\text { programs for which the entire CIP Code has been terminated and removed from the university's } \\
\text { inventory of degree programs. Suspended Programs are degree programs for which enrollments have } \\
\text { been temporarily suspended for the entire CIP Code, but the program CIP Code has not been } \\
\text { terminated. }\end{array}$} \\
\hline
\end{tabular}

\begin{tabular}{|c|c|c|c|c|c|}
\hline & 2005-06 & 2006-07 & 2007-08 & 2008-09 & 2009-10 \\
\hline Masters and Specialist & 2,081 & 2,113 & 2,314 & 2,482 & 2,544 \\
\hline Research Doctoral & 184 & 223 & 229 & 248 & 244 \\
\hline Professional Doctoral & 93 & 122 & 143 & 154 & 156 \\
\hline a) Medicine & 93 & 116 & 115 & 114 & 116 \\
\hline b) Law & 0 & 0 & 0 & 0 & 0 \\
\hline c) Pharmacy & 0 & 0 & 0 & 0 & 0 \\
\hline
\end{tabular}


Section 5 - Graduate Education (continued)

\begin{tabular}{|c|c|c|c|c|c|}
\hline \multicolumn{7}{|c|}{ TABLE 5C. Graduate Degrees Awarded in Areas of Strategic Emphasis } \\
\hline & $\mathbf{2 0 0 5 - 0 6}$ & $\mathbf{2 0 0 6 - 0 7}$ & $\mathbf{2 0 0 7 - 0 8}$ & $\mathbf{2 0 0 8 - 0 9}$ & $\mathbf{2 0 0 9 - 1 0}$ \\
\hline Education & 170 & 193 & 194 & 234 & 188 \\
\hline Health Professions & 387 & 428 & 429 & 506 & 566 \\
\hline $\begin{array}{c}\text { Science, Technology, } \\
\text { Engineering, and Math }\end{array}$ & 429 & 454 & 544 & 530 & 616 \\
\hline $\begin{array}{c}\text { Security and Emergency } \\
\text { Services }\end{array}$ & 33 & 6 & 36 & 53 & 40 \\
\hline Globalization & 37 & 42 & 46 & 41 & 54 \\
\hline
\end{tabular}

\section{TABLE 5D. Professional Licensure Exams - Graduate Programs}

Medicine: US Medical Licensing Exam (Step 1)

\begin{tabular}{|c|c|c|c|c|c|}
\hline & 2006 & 2007 & 2008 & 2009 & 2010 \\
\hline Examinees & 116 & 112 & 117 & 117 & 114 \\
\hline Pass Rate & $94 \%$ & $95 \%$ & $97 \%$ & $97 \%$ & $95 \%$ \\
\hline National Benchmark & $95 \%$ & $94 \%$ & $93 \%$ & $93 \%$ & $92 \%$ \\
\hline \multicolumn{6}{|c|}{ Medicine: US Medical Licensing Exam (Step 2) Clinical Knowledge } \\
\hline & $2005-06$ & 2006-07 & 2007-08 & 2008-09 & 2009-10 \\
\hline Examinees & 110 & 111 & 101 & 121 & 96 \\
\hline Pass Rate & $95 \%$ & $100 \%$ & $100 \%$ & $100 \%$ & $100 \%$ \\
\hline National Benchmark & $94 \%$ & $95 \%$ & $96 \%$ & $96 \%$ & $97 \%$ \\
\hline \multicolumn{6}{|c|}{ Medicine: US Medical Licensing Exam (Step 2) Clinical Skills } \\
\hline & $2005-06$ & 2006-07 & 2007-08 & 2008-09 & 2009-10 \\
\hline Examinees & 111 & 126 & 92 & 118 & 109 \\
\hline Pass Rate & $95 \%$ & $95 \%$ & $97 \%$ & $97 \%$ & $95 \%$ \\
\hline National Benchmark & $98 \%$ & $97 \%$ & $97 \%$ & $97 \%$ & $97 \%$ \\
\hline
\end{tabular}

\section{Section 6 - Research and Economic Development}

\begin{tabular}{|c|c|c|c|c|c|}
\hline & 2004-05 & 2005-06 & $2006-07$ & 2007-08 & 2008-09 \\
\hline \multicolumn{6}{|l|}{ R\&D Awards } \\
\hline $\begin{array}{l}\text { Federally Funded Awards } \\
\text { (Thousand \$) }\end{array}$ & & & & & $\$ 188,272$ \\
\hline $\begin{array}{l}\text { Total Awards } \\
\text { (Thousand \$) }\end{array}$ & & & & & $\$ 282,993$ \\
\hline \multicolumn{6}{|l|}{ R\&D Expenditures } \\
\hline $\begin{array}{l}\text { Federally Funded } \\
\text { Expenditures } \\
\text { (Thousand \$) }\end{array}$ & $\$ 143,051$ & $\$ 157,324$ & $\$ 171,272$ & $\$ 189,282$ & $\$ 213,163$ \\
\hline $\begin{array}{l}\text { Total Expenditures } \\
\text { (Thousand \$) }\end{array}$ & $\$ 276,609$ & $\$ 304,804$ & $\$ 337,169$ & $\$ 342,665$ & $\$ 371,037$ \\
\hline $\begin{array}{l}\text { Total R\&D Expenditures } \\
\text { Per Full-Time, Tenured, } \\
\text { Tenure-Earning Faculty } \\
\text { Member }(\$)\end{array}$ & $\$ 238,662$ & $\$ 253,159$ & $\$ 278,652$ & $\$ 291,630$ & $\$ 336,389$ \\
\hline \multicolumn{6}{|l|}{ Technology Transfer } \\
\hline Invention Disclosures & 0 & 109 & 110 & 139 & 141 \\
\hline Total U.S. Patents Issued & 23 & 29 & 31 & 31 & 36 \\
\hline $\begin{array}{l}\text { Patents Issued Per } 1,000 \\
\text { Full-Time, Tenure and } \\
\text { Tenure-Earning Faculty }\end{array}$ & 20 & 24 & 26 & 26 & 28 \\
\hline $\begin{array}{l}\text { Total Number of Licenses/ } \\
\text { Options Executed }\end{array}$ & 20 & 21 & 23 & 28 & 25 \\
\hline $\begin{array}{l}\text { Total Licensing Income } \\
\text { Received (\$) }\end{array}$ & $\$ 1,548,818$ & $\$ 1,704,025$ & $\$ 2,099,712$ & $\$ 1,831,000$ & $\$ 1,300,000$ \\
\hline $\begin{array}{l}\text { Total Number of Start-Up } \\
\text { Companies }\end{array}$ & 6 & 6 & 4 & 5 & 3 \\
\hline \multicolumn{6}{|c|}{$\begin{array}{l}\text { Note: Awards and Expenditures are based on the National Science Foundation's annual Survey of R\&D } \\
\text { Expenditures at Universities and Colleges (data include Science \& Engineering and non-Science \& } \\
\text { Engineering awards). Technology Transfer data are based on the Association of University Technology } \\
\text { Managers Annual Licensing Survey. }\end{array}$} \\
\hline
\end{tabular}




\section{Section 6 - Research and Economic Development (continued)}

\section{TABLE 6B. Centers of Excellence}

Florida Center of Excellence for

Name of Center:

Biomolecular Identification and

Year Created:

Targeted Therapeutics

2007

Research Effectiveness

Only includes data for activities directly associated with the Center. Does not include the non-Center activities for faculty who are associated with the Center.

Number of Competitive Grants Applied For

Value of Competitive Grants Applied For (\$)

Number of Competitive Grants Received

Value of Competitive Grants Received (\$)

Total Research Expenditures (\$)

Number of Publications in Refereed Journals

From Center Research

Number of Invention Disclosures

Number of Licenses/Options Executed

Licensing Income Received (\$)

Cumulative since inception to June 2010)

Fiscal Year 2009-10

\section{Collaboration Effectiveness}

Only reports on relationships that include financial or in-kind support.

Collaborations with Other Postsecondary Institutions

Collaborations with Private Industry

Collaborations with K-12 Education Systems/Schools

Undergraduate and Graduate Students Supported

with Center Funds

ness

Number of Start-Up companies

with a physical presence, or employees, in Florida

Jobs Created By Start-Up Companies

Associated with the Center

Specialized Industry Training and Education

Private-sector Resources Used to Support

the Center's Operations

Narrative Comments on next page.

\section{Section 6 - Research and Economic Development (continued)}

\section{TABLE 6B. Centers of Excellence}

Name of Center

Florida Center of Excellence for Biomolecular Identification and Targeted Therapeutics

Narrative Comments [Most Recent Year]:

(1) FCoE-BITT partnered with Hillsborough Community College and the University of Florida to host an

industrial biotechnology workshop at HCC in Brandon.

(2) Marilyn Barger, Ph.D., Director of FLATE and the FCoE-BITT office at HCC, served as a lead organizer of the High Impact Technology and Exchange Conference - a conference on workforce education.

(3) FCoE-BITT provided instructors and facilities for courses towards the Masters in Biotechnology at USF

(4) Collaborative Study with HCC: BITT HCC has completed a study and a report has been generated titled, "Inventory for the Greater Tampa Bay Region's Biotechnology Industry." A follow on study to identify workforce development needs in the Tampa Bay region (Hillsborough, Pinellas, Polk, Pasco, Sarasota, Manatee and Hernando counties) that is specific to BITT missions is ongoing. The results of

these studies will be used to tailor course content or direct training at USF and the local community colleges.

(5) Ran an 8 hour course for 11 incumbent workers and students ("Working in a Regulated

Environment").

(6) Held a community college program advisory committee meeting in August 2009 with 5 industry partners.

(7) Ran a 1 week hands-on workshop for 29 regional science teachers in partnership with Bio-RAD and 2 out-of-state colleges.

Core Facilities providing services in Biotechnology Development and Testing, Proteomics and NMR Structural Biology were established. 
Section 6 - Research and Economic Development (continued)

\begin{tabular}{|l|c|c|}
\hline \multicolumn{1}{|c|}{ TABLE 6C. State University Research Commercialization Assistance Grants } \\
\multicolumn{1}{|c|}{ Project Name by Type of Grant } & Awards & Expenditures \\
\hline Phase I Grants & $\$ 50,000$ & $\$ 19,000$ \\
\hline Early Stage RAID & & $\$ 0$ \\
\hline $\begin{array}{l}\text { Phase II Grants } \\
\text { Platinum Compounds }\end{array}$ & $\$ 50,000$ & \\
\hline Phase III Grants & $\$ 100,000$ & $\$ 19,000$ \\
\hline
\end{tabular}

\section{Section 6 - Research and Economic Development (continued)}

TABLE 6C. State University Research Commercialization Assistance Grants

Narrative Comments: For each project, provide a brief update on (1) the project's progress towards completing its key milestones/deliverables; and (2) the project's return on investment for the university and state.

USF Phase I Early Stage RAID $(\$ 50,000)$. (1) Key milestones for this project included the submission and review of three RAID (now known as NExT) applications. The first submission to the RAID program

was declined but recommended for resubmission under the new program, NExT. No commentary was provided for the review, and the application is currently being redrafted for potential submission in the coming cycles. The learning curve was steep but the process is becoming streamlined and more efficient and should be completed over the next year. Two additional new projects were submitted specifically under the NExT program.

Both projects were reviewed and comments were provided indicating that upon resubmission these two projects might be selected. Further, an additional staff member of the office was trained in the process of writing these applications. (2) The return on investment for this Grant is multifold. First, positive commentary from the reviewers of the two NExT grants indicates that the USF Division of Patents \&

Licensing is proficient in writing these applications, and that the shortcomings can be addressed through additional work by the faculty member. Second, the commentary identified the key areas of each project that are necessary in order to bring the project to a level where commercialization is likely. Third, the

potential for successful selection of the projects is very high based upon the suggestions for resubmission of both projects. Lastly, the training funded under this grant the ability of the USF Division of Patents \& Licensing to successfully execute related commercialization grants, such as the Technology Transfer Funds offered through the Florida Biomedical Program, as well as afforded the potential to draft successful SBIRs and STTRs.

USF Phase II Platinum Compounds $(\$ 50,000)$ : (1) Key milestones for this project included creating a business plan for the commercialization of anti-cancer drug compounds. During this process, it was identified that key areas of need for the platinum compounds under assessment were the ability to synthesize the compounds and evaluation of their mechanism of action in order to move forward with preclinical evaluation. USF has expended $\$ 43,000$ on further assessment and development toward

synthesis. The assessments provided by experts contracted in the field have led us to the conclusion that the platinum-based compounds would be much more difficult to produce than originally anticipated. A similar assessment of a separate class of anticancer compounds, palmerolides, was conducted with

results suggesting an excellent opportunity to synthesize the drugs. We have begun moving forward with initiating the business plan around the palmerolides including independent assessment of the synthetic process and preclinical needs in support of an Investigational New Drug Application (IND). This Grant will also fund the drafting of an SBIR that will be directed to the goal of conducting specific preclinical animal testing as required by the FDA prior to IND submission. (2) The return on investmen for this Grant include the independent assessment of multiple compounds for synthesis and preclinical testing which adds to accuracy of the business plan under development and greatly increases the potential commercial value of the technologies should they be licensed. Additionally, the Grant will provide resources to quickly push the business plan in the direction of the more feasible development of palmerolides as anti-cancer agents, again generating critical independent evaluation. The expectation is that these efforts should be completed over the next year. 
Section 6 - Research and Economic Development (continued)

\begin{tabular}{|c|c|c|c|c|c|c|}
\hline \multirow[b]{2}{*}{$\begin{array}{l}\text { World Class } \\
\text { Scholar(s) }\end{array}$} & \multirow[b]{2}{*}{$\begin{array}{l}\text { Scholar's } \\
\text { Field }\end{array}$} & \multicolumn{2}{|c|}{ Grant Dollars } & \multicolumn{3}{|c|}{$\begin{array}{l}\text { Report the cumulative activity } \\
\text { since each scholar's award. }\end{array}$} \\
\hline & & $\begin{array}{c}\text { Amount } \\
\text { Awarded } \\
\text { (Thousand \$) }\end{array}$ & $\begin{array}{l}\text { Cumulative } \\
\text { Amount } \\
\text { Expended } \\
\text { (Thousand \$) }\end{array}$ & $\begin{array}{l}\text { External } \\
\text { Research } \\
\text { Awards } \\
\text { (Thousand \$) }\end{array}$ & $\begin{array}{l}\text { Patents } \\
\text { Filed/ } \\
\text { Issued }\end{array}$ & $\begin{array}{c}\text { Licensing } \\
\text { Revenues } \\
\text { Generated } \\
\text { (\$) }\end{array}$ \\
\hline $\begin{array}{l}\text { James } \\
\text { Mihelcic }\end{array}$ & & $\$ 1,000$ & $\$ 1,000$ & $\$ 642$ & 0 & $\$ 0$ \\
\hline John Adams & & $\$ 1,000$ & $\$ 1,000$ & $\$ 4,739$ & 0 & $\$ 0$ \\
\hline $\begin{array}{l}\text { Richard } \\
\text { Gitlin }\end{array}$ & & $\$ 1,000$ & $\$ 1,000$ & $\$ 0$ & 0 & $\$ 0$ \\
\hline $\begin{array}{l}\text { Thomas } \\
\text { Unnasch }\end{array}$ & & $\$ 1,000$ & $\$ 1,000$ & $\$ 4,933$ & 1 & $\$ 0$ \\
\hline TOTAL & & $\$ 4,000$ & $\$ 4,000$ & $\$ 10,314$ & 0 & $\$ 0$ \\
\hline \multicolumn{7}{|c|}{ Narrative Comments } \\
\hline \multicolumn{7}{|c|}{$\begin{array}{l}\text { The grant dollars awarded per scholar include the initial award amount and corresponding match } \\
\text { dollars. } \\
{ }^{*} \text { Dr. Gitlin has submitted grant proposals totaling } \$ 548,230 \text {. } \\
*^{*} \text { Cumulative Amount Expended as of } 10 / 26 / 10(\text { ppe } 9 / 30 / 10) \\
\text { Drs John Adams and Thomas Unnasch have expended their total award amount }\end{array}$} \\
\hline
\end{tabular}

University of South Florida - Page 14 
State University System of Florida 2010 Annual Report Data Definitions 
This page is intentionally left blank.

2010 Annual Report Data Definitions - Page 2 


\begin{tabular}{|c|c|}
\hline \\
\hline $\begin{array}{l}\text { Recurring State Funds } \\
{ }^{*} \text { REVISED }\end{array}$ & $\begin{array}{l}\text { Definition: State recurring funds include general revenue and lottery education } \\
\text { and general appropriations and any administered funds provided by the } \\
\text { state. This does not include technical adjustments or transfers made by } \\
\text { Universities after the appropriation. } \\
\text { Source: Final Amendment Package (Total E\&G \& Lottery minus Non-Recurring - see } \\
\text { below) }\end{array}$ \\
\hline $\begin{array}{l}\text { Non-Recurring State } \\
\text { Funds } \\
\text { *REVISED }\end{array}$ & $\begin{array}{l}\text { Definition: State non-recurring funds include general revenue and lottery } \\
\text { education and general appropriations and any administered funds provided } \\
\text { by the state. This does not include technical adjustments or transfers made by } \\
\text { Universities after the appropriation. } \\
\text { Source: Non-Recurring Appropriations Section of annual Allocation Summary } \\
\text { document and all other Non-Recurring Budget Amendments allocated later in } \\
\text { the fiscal year. }\end{array}$ \\
\hline $\begin{array}{l}\text { Tuition } \\
\text { (Resident/ Non- } \\
\text { Resident) }\end{array}$ & $\begin{array}{l}\text { Definition: Actual tuition revenues collected from resident and non-resident } \\
\text { students. } \\
\text { Source: Operating Budget, Report } 625 \text { - Schedule I-A }\end{array}$ \\
\hline $\begin{array}{l}\text { Tuition Differential } \\
\text { Fee }\end{array}$ & $\begin{array}{l}\text { Definition: Actual tuition differential revenues collected from undergraduate } \\
\text { students. } \\
\text { Source: Operating Budget, Report } 625 \text { - Schedule I-A }\end{array}$ \\
\hline Other Fees & $\begin{array}{l}\text { Definition: Other revenue collections include items such as application fees, late } \\
\text { registration fees, library fines, miscellaneous revenues. This is the total } \\
\text { revenue from Report } 625 \text { minus tuition and tuition differential fee revenues. } \\
\text { This does not include local fees. } \\
\text { Source: Operating Budget, Report } 625 \text { - Schedule I-A }\end{array}$ \\
\hline $\begin{array}{l}\text { Phosphate Research } \\
\text { Trust Fund }\end{array}$ & $\begin{array}{l}\text { Definition: State appropriation for the Institute of Phosphate Research at the } \\
\text { University of South Florida. For UF-IFAS and UF-HSC, actual revenues from } \\
\text { the Incidental Trust Fund and Operations \& Maintenance Trust Fund are } \\
\text { provided by the University of Florida and included as 'Other Operating Trust } \\
\text { Funds' } \\
\text { Source: Final Amendment Package }\end{array}$ \\
\hline $\begin{array}{l}\text { Federal Stimulus } \\
\text { Funds }\end{array}$ & $\begin{array}{l}\text { Definition: Non-recurring American Recovery and Reinvestment Act funds } \\
\text { appropriated by the state. } \\
\text { Source: Final Amendment Package }\end{array}$ \\
\hline \multicolumn{2}{|c|}{$\begin{array}{l}\text { Table 1B. E\&G Expenditures } \\
\text { The table reports the actual and estimated amount of expenditures from revenues appropriated by the } \\
\text { legislature for each fiscal year. The expenditures are classified by Program Component (i.e., } \\
\text { Instruction/ Research, PO\&M, Administration, etc...) for activities directly related to instruction, research } \\
\text { and public service. The table does not include expenditures classified as non-operating expenditures (i.e., } \\
\text { to service asset-related debts), and therefore excludes a small portion of the amount appropriated each } \\
\text { year by the legislature. Also, the table does not include expenditures from funds carried forward from } \\
\text { previous years. }\end{array}$} \\
\hline Instruction \& Research & $\begin{array}{l}\text { Definition: Includes expenditures for state services related to the instructional } \\
\text { delivery system for advanced and professional education. Includes functions } \\
\text { such as; all activities related to credit instruction that may be applied toward a } \\
\text { postsecondary degree or certificate; non-project research and service } \\
\text { performed to maintain professional effectives; individual or project research; }\end{array}$ \\
\hline
\end{tabular}

\begin{tabular}{|c|c|}
\hline & $\begin{array}{l}\text { academic computing support; academic source or curriculum development. } \\
\text { Source: Operating Budget Summary - Expenditures by Program Activity (or } \\
\text { Report 645). }\end{array}$ \\
\hline Institutes \& Centers & $\begin{array}{l}\text { Definition: Includes state services related to research organizations designed for } \\
\text { mission-oriented, fundamental, and applied research projects. } \\
\text { Source: Operating Budget Summary - Expenditures by Program Activity (or Report } \\
\text { 645). }\end{array}$ \\
\hline PO\&M & $\begin{array}{l}\text { Definition: Plant Operations \& Maintenance expenditures related to the } \\
\text { cleaning and maintenance of existing grounds, the providing of utility } \\
\text { services, and the planning and design of future plant expansion and } \\
\text { modification } \\
\text { Source: Operating Budget Summary - Expenditures by Program Activity (or Report } \\
\text { 645). }\end{array}$ \\
\hline $\begin{array}{l}\text { Administration \& } \\
\text { Support Services }\end{array}$ & $\begin{array}{l}\text { Definition: Expenditures related to the executive direction and leadership for } \\
\text { university operations and those internal management services which assist } \\
\text { and support the delivery of academic programs. } \\
\text { Source: Operating Budget Summary - Expenditures by Program Activity (or Report } \\
\text { 645). }\end{array}$ \\
\hline Radio/TV & $\begin{array}{l}\text { Definition: Services related to the operation and maintenance of public } \\
\text { broadcasting which is intended for the general public. } \\
\text { Source: Operating Budget Summary - Expenditures by Program Activity (or Report } \\
\text { 645). }\end{array}$ \\
\hline Library/Audio Visual & $\begin{array}{l}\text { Definition: Expenditures include state services related to collecting, cataloging, } \\
\text { storing, and distributing library materials. } \\
\text { Source: Operating Budget Summary - Expenditures by Program Activity (or Report } \\
\text { 645). }\end{array}$ \\
\hline Museums \& Galleries & $\begin{array}{l}\text { Definition: Expenditures related to the collection, preservation, and exhibition } \\
\text { of historical materials, art objects, scientific displays and other objects at the } \\
\text { UF Florida State Museum \& Harn Museum; FSU Ringling Museum; FAMU } \\
\text { Black Archives Museum; USF Contemporary Art Museum; FIU Wolfsonian } \\
\text { Museum; and UWF Historic Preservation Board. } \\
\text { Source: Operating Budget Summary - Expenditures by Program Activity (or Report } \\
\text { 645). }\end{array}$ \\
\hline Student Services & $\begin{array}{l}\text { Definition: Includes resources related to physical, psychological, and social well } \\
\text { being of the student. Includes student service administration, social and } \\
\text { cultural development, counseling and career guidance, financial aid, and } \\
\text { student admissions and records. } \\
\text { Source: Operating Budget Summary - Expenditures by Program Activity (or Report } \\
\text { 645). }\end{array}$ \\
\hline $\begin{array}{l}\text { Teaching Hospitals } \\
\text { \& Allied Clinics }\end{array}$ & $\begin{array}{l}\text { Definition: Includes resources related to services that benefit patients directly } \\
\text { through faculty physicians, or indirectly through consulting, laboratory, or } \\
\text { other services usually performed by a hospital or clinic. Includes only the } \\
\text { clinical portions of a teaching hospital or veterinary clinic, and does not } \\
\text { include instruction, research, or administration. } \\
\text { Source: Operating Budget Summary - Expenditures by Program Activity (or Report } \\
\text { 645). }\end{array}$ \\
\hline $\begin{array}{l}\text { Intercollegiate } \\
\text { Athletics }\end{array}$ & $\begin{array}{l}\text { Definition: Includes expenditures associated with Title IX activities and } \\
\text { compliance. } \\
\text { Source: Operating Budget, manual submission. }\end{array}$ \\
\hline
\end{tabular}

2010 Annual Report Data Definitions - Page 3 


\begin{tabular}{|c|c|}
\hline \multicolumn{2}{|c|}{ Table 1C. State Funding per Student } \\
\hline $\begin{array}{l}\text { Appropriated Funding } \\
\text { per FTE }\end{array}$ & $\begin{array}{l}\text { Definition: Education \& General appropriations (includes the tuition and fees } \\
\text { budget authority appropriated by the Legislature) are divided by total actual } \\
\text { FTE students. Only state-fundable credit hours are used. To allow for } \\
\text { national comparisons, FTE students for this metric uses the standard IPEDS } \\
\text { definition of a FTE student, equal to } 30 \text { credit hours for undergraduate } \\
\text { students and } 24 \text { for graduate students. This does not include appropriations } \\
\text { for special units (i.e., IFAS, Health Science Centers, and Medical Schools). } \\
\text { Tuition and fee revenues include tuition and tuition differential fee and E\&G } \\
\text { fees (i.e., application, late registration, and library fees/fines). Other local fees } \\
\text { that do not support E\&G activities are not included here (see Board of } \\
\text { Governors Regulation 7.003). } \\
\text { Sources: Education \& General Appropriations (for revenue), SUS Student } \\
\text { Instruction File (for FTE enrollment) }\end{array}$ \\
\hline $\begin{array}{l}\text { Actual Funding per } \\
\text { FTE } \\
{ }^{*} \text { NEW }\end{array}$ & $\begin{array}{l}\text { Definition: This data is the same as the above appropriated funding per FTE } \\
\text { with the exception that this includes the tuition and fees actually collected } \\
\text { (rather than budget authority). } \\
\text { Sources: Education \& General Appropriations (for revenue), SUS Student } \\
\text { Instruction File (for FTE enrollment), and Operating Budget, Report } 625 \text { - } \\
\text { Schedule I-A }\end{array}$ \\
\hline \multicolumn{2}{|c|}{ Table 1D. Other Budget Entities } \\
\hline Contracts \& Grants & $\begin{array}{l}\text { Definition: Resources received from federal, state or private sources for the } \\
\text { purposes of conducting research and public service activities. Revenues do } \\
\text { not include transfers. Expenditures do not include non-operating } \\
\text { expenditures. } \\
\text { Source: Operating Budget, Report } 615 \text {. }\end{array}$ \\
\hline Auxiliary Enterprises & $\begin{array}{l}\text { Definition: Resources associated with auxiliary units that are self supporting } \\
\text { through fees, payments and charges. Examples include housing, food } \\
\text { services, bookstores, parking services, health centers. Revenues do not } \\
\text { include transfers. Expenditures do not include non-operating expenditures. } \\
\text { Source: Operating Budget, Report } 615 \text {. }\end{array}$ \\
\hline Local Funds & $\begin{array}{l}\text { Definition: Resources associated with student activity (supported by the } \\
\text { student activity fee), student financial aid, concessions, intercollegiate } \\
\text { athletics, and technology fee. Revenues do not include transfers. } \\
\text { Expenditures do not include non-operating expenditures. } \\
\text { Source: Operating Budget, Report 615. (Self Insurance is a manual submission } \\
\text { and has not been included). }\end{array}$ \\
\hline \multicolumn{2}{|c|}{ Table 1E. Total Revenues and Expenditures } \\
\hline $\begin{array}{l}\text { Total Revenues and } \\
\text { Expenditures }\end{array}$ & $\begin{array}{l}\text { This is a sum of all revenues and expenditures for each university, health- } \\
\text { science center and IFAS. }\end{array}$ \\
\hline \multicolumn{2}{|c|}{ Table 1F. Voluntary Support for Higher Education } \\
\hline $\begin{array}{l}\text { Endowment Market } \\
\text { Value }\end{array}$ & $\begin{array}{l}\text { Definition: Endowment value at the end of the fiscal year, as reported in the } \\
\text { annual NACUBO Endowment Study (changed to the NACUBO-Common } \\
\text { Fund Study of Endowments in 2009). } \\
\text { Source: NACUBO Endowment Study (or using NACUBO definitions for } \\
\text { institutions that do not participate in that survey) }\end{array}$ \\
\hline
\end{tabular}

\begin{tabular}{|c|c|}
\hline Annual Gifts Received & $\begin{array}{l}\text { Definition: As reported in the Council for Aid to Education's Voluntary } \\
\text { Support of Education (VSE) survey in the section entitled "Gift Income } \\
\text { Summary," this is the sum of the present value of all gifts (including outright } \\
\text { and deferred gifts) received for any purpose and from all sources during the } \\
\text { fiscal year, excluding pledges and bequests. (There's a deferred gift } \\
\text { calculator at www.cae.org/vse.) The present value of non-cash gifts is } \\
\text { defined as the tax deduction to the donor as allowed by the IRS. } \\
\text { Source: Voluntary Support of Education survey (or using VSE definitions for } \\
\text { institutions that do not participate in that survey) }\end{array}$ \\
\hline $\begin{array}{l}\text { Percentage of Alumni } \\
\text { Who Are Donors }\end{array}$ & $\begin{array}{l}\text { Definition: As reported in the Council for Aid to Education's Voluntary } \\
\text { Support of Education (VSE) survey in the section entitled "Additional } \\
\text { Details," this is the number of alumni donors divided by the total number of } \\
\text { alumni, as of the end of the fiscal year. "Alumni," as defined in this survey, } \\
\text { include those holding a degree from the institution as well as those who } \\
\text { attended the institution but did not earn a degree. } \\
\text { Source: Voluntary Support of Education survey (or using VSE definitions for } \\
\text { institutions that do not participate in that survey) }\end{array}$ \\
\hline & Section 2 - Personnel \\
\hline $\begin{array}{l}\text { Tenure/ } \mathrm{T} \\
\text { Faculty }\end{array}$ & $\begin{array}{l}\text { Definition: All tenured and all tenure-track faculty (including medical schools) } \\
\text { for the combined instruction, research, and public service functional } \\
\text { categories. } \\
\text { Source: IPEDS Human Resources Survey, online title "Full- and part-time } \\
\text { medical and non-medical staff by faculty status and primary } \\
\text { function/occupational activity" }\end{array}$ \\
\hline $\begin{array}{l}\text { Not on Tenure Track } \\
\text { Faculty }\end{array}$ & $\begin{array}{l}\text { Definition: All non-tenure-track faculty (including medical school) for the } \\
\text { combined instruction, research, and public service functional. This includes } \\
\text { adjunct faculty and faculty on multi-year contracts. } \\
\text { Source: IPEDS Human Resources Survey, online title "Full- and part-time } \\
\text { medical and non-medical staff by faculty status and primary } \\
\text { function/occupational activity" }\end{array}$ \\
\hline $\begin{array}{l}\text { Without Fa } \\
{ }^{*} \text { NEW }\end{array}$ & $\begin{array}{l}\text { Definition: All personnel without faculty status (including medical school) for } \\
\text { all functional categories: Primary instruction + Instruction/ research/public } \\
\text { service + Primarily research + Primarily public service). Individuals hired as a } \\
\text { staff member primarily to do research on a 3-year contract without tenure } \\
\text { eligibility should be reported as Primarily research in the Not on tenure track } \\
\text { column. A postdoctoral research associate, because they do not have faculty } \\
\text { status, would be reported as Primarily research in the Without faculty status. } \\
\text { Source: IPEDS Human Resources Survey, online title "Full- and part-time } \\
\text { medical and non-medical staff by faculty status and primary } \\
\text { function/occupational activity" }\end{array}$ \\
\hline $\begin{array}{l}\text { Graduate Assistants/ } \\
\text { Associates }\end{array}$ & $\begin{array}{l}\text { Definition: Total graduate assistants } \\
\text { Source: IPEDS Human Resources Survey, online title “Full- and part-time } \\
\text { medical and non-medical staff by faculty status and primary } \\
\text { function/occupational activity" }\end{array}$ \\
\hline $\begin{array}{l}\text { Executive/ } \\
\text { Administrative/ } \\
\text { Managerial }\end{array}$ & $\begin{array}{l}\text { Definition: Total executive/administrative and managerial positions regardless } \\
\text { of faculty status } \\
\text { Source: IPEDS Human Resources Survey, online title "Full- and part-time } \\
\text { medical and non-medical staff by faculty status and primary } \\
\text { function/occupational activity" }\end{array}$ \\
\hline
\end{tabular}




\begin{tabular}{|c|c|}
\hline Other Professional & $\begin{array}{l}\text { Definition: Total other professional positions (support/service) regardless of } \\
\text { faculty status } \\
\text { Source: IPEDS Human Resources Survey, online title "Full- and part-time } \\
\text { medical and non-medical staff by faculty status and primary } \\
\text { function/occupational activity" }\end{array}$ \\
\hline Non-Professional & $\begin{array}{l}\text { Definition: Total non-professional positions } \\
\text { Source: IPEDS Human Resources Survey, online title "Full- and part-time } \\
\text { medical and non-medical staff by faculty status and primary } \\
\text { function/occupational activity" }\end{array}$ \\
\hline \multicolumn{2}{|r|}{ Section 3 - Enrollment \& Space } \\
\hline $\begin{array}{l}\text { Table 3A. } \\
\text { FTE Enrollment - } \\
\text { Funded }\end{array}$ & $\begin{array}{l}\text { Definition: This metric reports the funded enrollment as reported in the } \\
\text { General Appropriations Act and set by the legislature. Note: FTE in this } \\
\text { instance uses the Florida definition of FTE, equal to } 40 \text { credit hours for } \\
\text { undergraduates and } 32 \text { for graduates. } \\
\text { Source: General Appropriations Act (with Graduate detail provided in annual } \\
\text { Allocation Summary document - Section: Instruction and Research. Link: } \\
\text { http://www.flbog.org/about/budget/allocation_summary.php) }\end{array}$ \\
\hline $\begin{array}{l}\text { Table } 3 \mathrm{~A} \text {. } \\
\text { FTE Enrollment - } \\
\text { Actual }\end{array}$ & $\begin{array}{l}\text { Definition: This metric reports the actual enrollment as reported by } \\
\text { Universities to the Board of Governors in the Student Instruction File (SIF). } \\
\text { Note: FTE in this instance uses the Florida definition of FTE, equal to } 40 \\
\text { credit hours for undergraduates and } 32 \text { for graduates. } \\
\text { Source: SUS Student Instruction File }\end{array}$ \\
\hline $\begin{array}{l}\text { Table 3A. } \\
\text { FTE Enrollment - } \\
\text { Estimated }\end{array}$ & $\begin{array}{l}\text { Definition: This metric reports the estimated enrollment as reported by } \\
\text { Universities to the Board of Governors in their Enrollment Plans. Note: FTE } \\
\text { in this instance uses the Florida definition of FTE, equal to } 40 \text { credit hours for } \\
\text { undergraduates and } 32 \text { for graduates. } \\
\text { Source: SUS Enrollment Plans }\end{array}$ \\
\hline \multicolumn{2}{|c|}{ Table 3B. Enrollment by Location } \\
\hline $\begin{array}{l}\text { Table 3B. } \\
\text { FTE Enrollment - } \\
\text { Actual }\end{array}$ & $\begin{array}{l}\text { Definition: This metric reports the actual enrollments for each distinct location } \\
\text { (main, branch, site, regional campus) with more than } 150 \text { FTE (state fundable } \\
\text { credit hours) as reported by Universities to the Board of Governors in the } \\
\text { Student Instruction File (SIF). } \\
\text { Source: SUS Student Instruction File }\end{array}$ \\
\hline $\begin{array}{l}\text { Table 3B. } \\
\text { FTE Enrollment - } \\
\text { Estimated }\end{array}$ & $\begin{array}{l}\text { Definition: This metric reports the estimated enrollments for each distinct } \\
\text { location (main, branch, site, regional campus) with more than } 150 \text { FTE (state } \\
\text { fundable credit hour) as reported by Universities to the Board of Governors } \\
\text { in their Enrollment Plans. } \\
\text { Source: SUS Enrollment Plans }\end{array}$ \\
\hline \multicolumn{2}{|c|}{ Table 3C. Space Utilization } \\
\hline $\begin{array}{l}\text { Table 3C. } \\
\text { Instructional Space } \\
\text { Utilization Rate } \\
\text { *SCHEDULED FOR } \\
\text { THE } 2011 \text { REPORT }\end{array}$ & $\begin{array}{l}\text { UPDATE: Board of Governors and university staff are currently conducting an } \\
\text { analysis of how space utilization is calculated. Until the analysis is complete, } \\
\text { no space utilization data will be included in the Annual Report. }\end{array}$ \\
\hline & Section 4 - Undergraduate Education Data \\
\hline $\begin{array}{l}\text { Table 4A. } \\
\text { Baccalaureate Degree } \\
\text { Program Changes in } \\
\text { AY 2009-10 }\end{array}$ & $\begin{array}{l}\text { New Programs - Proposed new degree programs that have been completely } \\
\text { through the approval process at the university, and if appropriate, the Board } \\
\text { of Governors. Do not include new majors or concentrations added under an } \\
\text { existing degree program CIP Code. }\end{array}$ \\
\hline
\end{tabular}

\begin{tabular}{|c|c|}
\hline & $\begin{array}{l}\text { Terminated Programs - Degree programs for which the entire CIP Code has } \\
\text { been terminated and removed from the university's inventory of degree } \\
\text { programs. Do not include majors or concentrations terminated under an } \\
\text { existing degree program CIP Code if the code is to remain active on the } \\
\text { academic degree inventory. } \\
\text { Suspended Programs - Degree programs for which enrollments have been } \\
\text { temporarily suspended for the entire CIP Code, but the program CIP Code } \\
\text { has not been terminated. Do not include majors or concentrations suspended } \\
\text { under an existing degree program CIP Code if the code is to remain active on } \\
\text { the academic degree inventory and new enrollments in any active major will } \\
\text { be reported. } \\
\text { New Programs Considered by University, But Not Approved - Include any } \\
\text { programs considered by the university board of trustees, or any committee of } \\
\text { the board, but not approved for implementation. Also include any programs } \\
\text { that were returned prior to board consideration by the university } \\
\text { administration for additional development, significant revisions, or re- } \\
\text { conceptualization; regardless of whether the proposal was eventually taken } \\
\text { to the university board for approval. Count the returns once per program, } \\
\text { not multiple times the proposal was returned for revisions, unless there is a } \\
\text { total re-conceptualization that brings forward a substantially different } \\
\text { program in a different CIP Code. Do not include new majors or } \\
\text { concentrations added under an existing degree program CIP Code. } \\
\text { Source: University Submission. This table reports the program changes } \\
\text { between May 5, } 2009 \text { and May } 4,2010 \text {. }\end{array}$ \\
\hline $\begin{array}{l}\text { Table 4B. } \\
\text { First-Year Persistence } \\
\text { Rates }\end{array}$ & $\begin{array}{l}\text { Definition: The percentage of a full-time, first-time-in-college (FTIC) } \\
\text { undergraduate cohort (entering in fall term or summer continuing to fall) } \\
\text { that is still enrolled or has graduated from the same institution in the second } \\
\text { year. } \\
\text { Source: SUS Retention File }\end{array}$ \\
\hline $\begin{array}{l}\text { Table 4C. } \\
\text { Federal Undergraduate } \\
\text { Progression and } \\
\text { Graduation Rates for } \\
\text { FTIC Students } \\
\text { *NEW }\end{array}$ & $\begin{array}{l}\text { Definition: Includes all full-time, first-time degree/certificate-seeking } \\
\text { undergraduate students entering the institution either during the fall term or } \\
\text { students enrolled in the fall term who attended college for the first time in the } \\
\text { prior summer term. The federal rate does not include students who originally } \\
\text { enroll as part-time students, or who transfer into the institution. This metric } \\
\text { complies with the requirements of the Student Right to Know Act that requires } \\
\text { institutions to report the completion status at } 150 \% \text { of normal time. } \\
\text { Source: SUS Retention file }\end{array}$ \\
\hline $\begin{array}{l}\text { Table } 4 \mathrm{D} \text {. } \\
\text { SUS Undergraduate } \\
\text { Progression and } \\
\text { Graduation Rates for } \\
\text { FTIC Students }\end{array}$ & $\begin{array}{l}\text { Definition: First-time-in-college (FTIC) cohort is defined as undergraduates } \\
\text { entering in fall term (or summer continuing to fall) with fewer than } 12 \text { hours } \\
\text { earned since high school graduation. The rate is the percentage of the initial } \\
\text { cohort that has either graduated or is still enrolled in the fourth or sixth } \\
\text { academic year. Both full-time and part-time students are used in the } \\
\text { calculation. PharmD students are removed from the cohorts if still enrolled } \\
\text { or graduated in the fourth year or later. } \\
\text { Source: SUS Retention File }\end{array}$ \\
\hline $\begin{array}{l}\text { Table 4E. } \\
\text { SUS Undergraduate } \\
\text { Progression and } \\
\text { Graduation Rates for } \\
\text { AA Transfer Students }\end{array}$ & $\begin{array}{l}\text { Definition: AA Transfer cohort is defined as undergraduates entering in the } \\
\text { fall term (or summer continuing to fall) and having earned an AA degree } \\
\text { from an institution in the Florida College System. The rate is the percentage } \\
\text { of the initial cohort that has either graduated or is still enrolled in the second } \\
\text { or fourth academic year. Both full-time and part-time students are used in }\end{array}$ \\
\hline
\end{tabular}




\begin{tabular}{|c|c|c|}
\hline & $\begin{array}{l}\text { the calculation. PharmD students are removed from the cohorts if still } \\
\text { enrolled or graduated in the second year or later. } \\
\text { Source: SUS Retention File }\end{array}$ \\
\hline \multicolumn{2}{|c|}{$\begin{array}{l}\text { Table } 4 \mathrm{~F} \text {. } \\
\text { SUS Undergraduate } \\
\text { Progression and } \\
\text { Graduation Rates for } \\
\text { Other Students }\end{array}$} & $\begin{array}{l}\text { Definition: Other Transfer cohort is defined as undergraduates entering in fall } \\
\text { term or summer continuing to fall who are not FTICs or AA transfers. The } \\
\text { rate is the percentage of this initial cohort that has graduated or is still } \\
\text { enrolled in the fifth academic year. Both full-time and part-time students are } \\
\text { used in the calculation. PharmD students are removed from the cohorts if } \\
\text { still enrolled in the fifth year or later. } \\
\text { Source: SUS Retention File }\end{array}$ \\
\hline \multicolumn{2}{|c|}{$\begin{array}{l}\text { Table 4G. } \\
\text { Baccalaureate Degrees }\end{array}$} & $\begin{array}{l}\text { Definition: This is a count of baccalaureate degrees granted. Students who } \\
\text { earn two distinct degrees in the same term are counted twice - whether their } \\
\text { degrees are from the same six-digit CIP code or different CIP codes. } \\
\text { Students who earn only one degree are counted once - even if they } \\
\text { completed multiple majors or tracks. } \\
\text { Technical note: Within SUDS, there are two scenarios in which a student is considered } \\
\text { to have been awarded two degrees within the same term: } \\
\text { - Two degree records are reported for one student, and both degrees have a } \\
\text { Major Indicator (field \#02015) equal to one; } \\
\text { - One degree record is reported for a student, but that degree has a Fraction of } \\
\text { Degree Granted (field \#01083) greater than one. } \\
\text { Source: SUS Degrees Awarded }\end{array}$ \\
\hline \multicolumn{2}{|c|}{$\begin{array}{l}\text { Table } 4 \mathrm{H} \text {. } \\
\text { Baccalaureate Degrees } \\
\text { Awarded in Areas of } \\
\text { Strategic Emphasis }\end{array}$} & $\begin{array}{l}\text { Definition: This is a count of baccalaureate majors for specific areas of strategic } \\
\text { emphasis, as determined by the Board of Governors staff with consultation } \\
\text { with business and industry groups and input from universities. So, a student } \\
\text { who has multiple majors in the subset of targeted Classification of Instruction } \\
\text { Program codes will be double-counted (i.e., double-majors are included). } \\
\text { Technical notes: This metric counts every record with a value greater than zero in the } \\
\text { Fraction of Degree (field \#01083) regardless of whether the Major Indicator (field } \\
\text { \#02015) is one, two, or three. If the Fraction of Degree is greater than one, then the } \\
\text { record will count as two degrees within that particular six-digit CIP code. } \\
\text { Source: SUS Degrees Awarded }\end{array}$ \\
\hline $\begin{array}{l}\text { Table } 4 \mathrm{I} . \\
\text { Non- } \\
\text { Hispanic } \\
\text { Black } \\
\text { Students } \\
\& \\
\text { Hispanic } \\
\text { Students }\end{array}$ & $\begin{array}{l}\text { Number } \\
\text { of } \\
\text { Baccalau- } \\
\text { reate } \\
\text { Degrees }\end{array}$ & $\begin{array}{l}\text { Definition: These metrics count the number of baccalaureate degrees granted } \\
\text { to non-Hispanic black students and Hispanic students. These metrics do not } \\
\text { include students classified as Non-Resident Alien or students with a missing } \\
\text { race code. Students who earn two distinct degrees in the same term are } \\
\text { counted twice - whether their degrees are from the same six-digit CIP code } \\
\text { or different CIP codes. Students who earn only one degree are counted once } \\
\text { - even if they completed multiple majors or tracks. } \\
\text { Technical note: Within SUDS, there are two scenarios in which a student is considered } \\
\text { to have been awarded two degrees within the same term: } \\
\text { - Two degree records are reported for one student, and both degrees have a } \\
\text { Major Indicator (field \#02015) equal to one; } \\
\text { - One degree record is reported for a student, but that degree has a Fraction of } \\
\text { Degree Granted (field \#01083) greater than one. } \\
\text { Source: SUS Degrees Awarded }\end{array}$ \\
\hline
\end{tabular}

\begin{tabular}{|c|c|c|}
\hline & $\begin{array}{l}\text { Percentage } \\
\text { of All } \\
\text { Baccalau- } \\
\text { reate } \\
\text { Degrees }\end{array}$ & $\begin{array}{l}\text { Definition: The number of baccalaureate degrees awarded to non-Hispanic } \\
\text { black students divided by the total degrees awarded, excluding those } \\
\text { awarded to non-resident aliens and unreported. } \\
\text { Source: SUS Degrees Awarded }\end{array}$ \\
\hline \multirow{3}{*}{$\begin{array}{l}\text { Table 4I. } \\
\text { Pell } \\
\text { Recipients } \\
\text { *REVISED }\end{array}$} & \multirow{2}{*}{$\begin{array}{l}\text { Number } \\
\text { of } \\
\text { Baccalau- } \\
\text { reate } \\
\text { Degrees }\end{array}$} & $\begin{array}{l}\text { Definition: The number of baccalaureate degrees granted to Pell recipients, } \\
\text { financial aid award code "001". A Pell recipient is defined as a student who } \\
\text { received Pell from any SUS institution within six years of graduation. This } \\
\text { metric does not include students classified as Non-Resident Alien (\#01044). } \\
\text { Students who earn two distinct degrees in the same term are counted twice - } \\
\text { whether their degrees are from the same six-digit CIP code or different CIP } \\
\text { codes. Students who earn only one degree are counted once - even if they } \\
\text { completed multiple majors or tracks. }\end{array}$ \\
\hline & & $\begin{array}{l}\text { Technical note: Within SUDS, there are two scenarios in which a student is considered } \\
\text { to have been awarded two degrees within the same term: } \\
\text { - Two degree records are reported for one student, and both degrees have a } \\
\text { Major Indicator (field \#02015) equal to one; } \\
\text { - One degree record is reported for a student, but that degree has a Fraction of } \\
\text { Degree Granted (field \#01083) greater than one. } \\
\text { Source: SUS Degrees Awarded File and Student Financial Aid File }\end{array}$ \\
\hline & \begin{tabular}{|l|} 
Percentage \\
of All \\
Baccalau- \\
reate \\
Degrees \\
\end{tabular} & $\begin{array}{l}\text { Definition: The number of baccalaureate degrees awarded to Pell recipients as } \\
\text { listed above is divided by the total degrees awarded excluding those } \\
\text { awarded to non-resident aliens, who are not eligible for Pell grants. } \\
\text { Source: SUS Student Instruction File and Student Financial Aid File }\end{array}$ \\
\hline \multicolumn{2}{|c|}{$\begin{array}{l}\text { Table } 4 \mathrm{~J} . \\
\% \text { of Total } \\
\text { Baccalaureate Degrees } \\
\text { Awarded Within } 110 \% \\
\text { of Hours Required for } \\
\text { Degree }\end{array}$} & $\begin{array}{l}\text { Definition: This table reports the percentage of baccalaureate degrees awarded } \\
\text { within } 110 \% \text { of the hours required for a degree. Excluding students with dual } \\
\text { majors, this metric computes total academic credit as a percentage of catalog } \\
\text { hours required for the students major (excluding remedial coursework). For } \\
\text { the purposes of calculating excess hours, remedial credit hours includes up } \\
\text { to } 10 \text { foreign language credit hours that are excluded for transfer students in } \\
\text { Florida. This metric is aligned with the calculation used in past legislative } \\
\text { accountability reports and performance funding calculations. } \\
\text { Source: SUS Hours to Degree File }\end{array}$ \\
\hline \multicolumn{2}{|c|}{$\begin{array}{l}\text { Table } 4 \mathrm{~K} . \\
\text { Number of } \\
\text { Undergraduate Course } \\
\text { Sections }\end{array}$} & $\begin{array}{l}\text { Definition: The Common Data Set (CDS) definition will be used. According to } \\
\text { CDS, a "class section is an organized course offered for credit, identified by } \\
\text { discipline and number, meeting at a stated time or times in a classroom or } \\
\text { similar setting, and not a subsection such as a laboratory or discussion } \\
\text { session. Undergraduate class sections are defined as any sections in which at } \\
\text { least one degree-seeking undergraduate student is enrolled for credit. } \\
\text { Exclude distance learning classes and noncredit classes and individual } \\
\text { instruction such as dissertation or thesis research, music instruction, or one- } \\
\text { to-one readings. Exclude students in independent study, co-operative } \\
\text { programs, internships, foreign language taped tutor sessions, practicums, } \\
\text { and all students in one-on-one classes. Each class section should be counted } \\
\text { only once and should not be duplicated because of course catalog cross- } \\
\text { listings." Certain portions of the CDS were summed to create groupings of } \\
\text { less than } 30 \text { students, between } 31 \text { and } 50 \text { students, between } 51 \text { and } 100 \\
\text { students, and more than } 100 \text { students. } \\
\text { Source: Common Data Set }\end{array}$ \\
\hline
\end{tabular}

2010 Annual Report Data Definitions - Page 6 


\begin{tabular}{|c|c|}
\hline $\begin{array}{l}\text { Table } 4 \mathrm{~L} \text {. } \\
\text { Faculty Teaching } \\
\text { Undergraduates }\end{array}$ & $\begin{array}{l}\text { Definition: The total number of undergraduate credit hours taught will be } \\
\text { divided by the undergraduate credit hours taught by each instructor type to } \\
\text { create a distribution of the percentage taught by each instructor type. Four } \\
\text { instructor types are defined as faculty (pay plans 01, 02, and 22), OPS faculty } \\
\text { (pay plan 06), graduate student instructors (pay plan 05), and others (all } \\
\text { other pay plans). If a course has more than one instructor, then the } \\
\text { university's reported allocation of section effort will determine the allocation } \\
\text { of the course's total credit hours to each instructor. } \\
\text { Source: Instruction and Research Data File }\end{array}$ \\
\hline $\begin{array}{l}\text { Table 4M. } \\
\text { Undergraduate } \\
\text { Instructional Faculty } \\
\text { Compensation }\end{array}$ & $\begin{array}{l}\text { Definition: Average salary and benefits for all instructors of undergraduate } \\
\text { courses who are on pay plan } 22 \text {. This amount is based on fall term data only, } \\
\text { and to make it more meaningful to the reader we annualize (to a fall + spring } \\
\text { amount) the fall-term salary and benefits. It is limited to faculty who taught } \\
\text { at least one undergraduate course in the fall term and is reported as } \\
\text { employed for at least } 0.1 \text { person year in the fall term. } \\
\text { Source: Instruction and Research Data File }\end{array}$ \\
\hline $\begin{array}{l}\text { Table } 4 \text { N. } \\
\text { Student-Faculty Ratio }\end{array}$ & $\begin{array}{l}\text { Definition: This definition will be consistent with Common Data Set (CDS) } \\
\text { reporting. This is the Fall ratio of full-time equivalent students (full-time plus } \\
1 / 3 \text { part time) to full-time equivalent instructional faculty (full time plus } 1 / 3 \\
\text { part time). In the ratio calculations, exclude both faculty and students in } \\
\text { stand-alone graduate or professional programs such as medicine, law, } \\
\text { veterinary, dentistry, social work, business, or public health in which faculty } \\
\text { teach virtually only graduate-level students. Do not count undergraduate or } \\
\text { graduate student teaching assistants as faculty. } \\
\text { Source: Common Data Set }\end{array}$ \\
\hline Nursing: NCLEX & $\begin{array}{l}\text { icensure Exams - Undergraduate Programs } \\
\text { Definition: Pass rate for first-time examinees for the National Council } \\
\text { Licensure Examination for Registered Nurses (NCLEX-RN) are based on the } \\
\text { performance of graduates of baccalaureate nursing programs. National } \\
\text { benchmark data is based on Jan-Dec NCLEX-RN results for first-time } \\
\text { examinees from students in US-educated baccalaureate degree programs as } \\
\text { published by the National Council of State Boards of Nursing. } \\
\text { Sources: Florida Department of Health: } \\
\text { http://www.doh.state.fl.us/mqa/nursing/nur_edu_info.html; } \\
\text { National Council of State Boards of Nursing:https://www.ncsbn.org/1237.htm }\end{array}$ \\
\hline $\begin{array}{l}\text { Teaching: FTCE - } \\
\text { Professional Education } \\
\text { Exam } \\
\text { *SCHEDULED FOR } \\
\text { THE } 2011 \text { REPORT }\end{array}$ & $\begin{array}{l}\text { Definition: Average pass rate for first-time examinees on the Florida Teacher } \\
\text { Certification Examination (FTCE) - Professional Education Examination are } \\
\text { based on the performance of cohorts of students in state-approved initial } \\
\text { educator preparation programs. Results are based on scores earned in the } \\
\text { senior year or up to one year after graduating. State benchmark data is based } \\
\text { on Jan-Dec FTCE-Professional Education exam results for all first-time } \\
\text { examinees. } \\
\text { Source: Florida Department of Education }\end{array}$ \\
\hline $\begin{array}{l}\text { Teaching: FTCE - } \\
\text { Subject Area Exams } \\
\text { (Aggregated) } \\
\text { *SCHEDULED FOR } \\
\text { THE } 2011 \text { REPORT }\end{array}$ & $\begin{array}{l}\text { Definition: Average pass rate for first-time examinees on the Florida Teacher } \\
\text { Certification Examination (FTCE) - Subject Area Examinations are based on } \\
\text { the performance of cohorts of students in state-approved initial educator } \\
\text { preparation programs. Results are based on scores earned in the senior year } \\
\text { or up to one year after graduating. State benchmark data is based on Jan-Dec } \\
\text { FTCE-Professional Education exam results for all first-time examinees. } \\
\text { Source: Florida Department of Education }\end{array}$ \\
\hline
\end{tabular}

Table 4P. Tuition Differential Fee

Total Revenues

Generated

By the Tuition

Differential

Unduplicated Count of

Students Receiving

Financial Aid Award

Funded by Tuition

Differential Revenues

*NEW

Average Amount of

Awards

Funded by Tuition

Differential Revenues

(per student receiving

an award) *NEW

Number of Prepaid

Tuition

Scholarship Recipients

*NEW

Number of Students

Eligible for FSAG

Definition: Actual tuition differential revenues collected from undergraduate students.

Source: Operating Budget, Report 625 - Schedule I-A

Definition: This reports the number of unduplicated students who have received a financial aid award that was funded by tuition differential revenues.

Source: Tuition Differential Proposals as submitted to the Board of Governors.

Definition: This reports the arithmetic mean for the amount each student (as defined above) received in awards funded by tuition differential revenues. Source: Tuition Differential Proposals as submitted to the Board of Governors.

Definition: Total annual unduplicated count of undergraduates at the institution who purchased a Prepaid Tuition Scholarship.

Source: Prepaid College Board (We plan to include a flag in the data provided to Universities.)

Definition: Total annual unduplicated count of undergraduates at the

institution who are eligible for FSAG in the academic year, whether or not they received FSAG awards.

Source: University submits this data based on their Student Financial Aid files.

Number of FSAG-

Receiving

a Waiver of the Tuition

a Waiver of

Differential

Definition: Annual unduplicated count of FSAG-eligible students receiving a waiver, partial or full, of the tuition differential fees at the institution during the academic year, regardless of the reason for the waiver.

Source: University submits this data based on their Student Financial Aid files.

Value of Tuition Differential Waivers

Provided to FSAG-

Definition: Value of all tuition differential fee waivers received by FSAGeligible undergraduates at the institution during the academic year,

regardless of the reason for the waiver.

Eligible Students

Source: University submits this data based on their Student Financial Aid files.

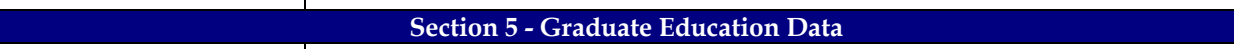

New Programs - Proposed new degree programs that have been completely through the approval process at the university, and if appropriate, the Board of Governors. Do not include new majors or concentrations added under an existing degree program CIP Code.

Table 5A.

Graduate Degree

Program Changes in

Terminated Programs - Degree programs for which the entire CIP Code has been terminated and removed from the university's inventory of degree programs. Do not include majors or concentrations terminated under an existing degree program CIP Code if the code is to remain active on the academic degree inventory.

Suspended Programs - Degree programs for which enrollments have been temporarily suspended for the entire CIP Code, but the program CIP Code has not been terminated. Do not include majors or concentrations suspended 


\begin{tabular}{|c|c|}
\hline & $\begin{array}{l}\text { under an existing degree program CIP Code if the code is to remain active on } \\
\text { the academic degree inventory and new enrollments in any active major will } \\
\text { be reported. } \\
\text { New Programs Considered by University, But Not Approved - Include any } \\
\text { programs considered by the university board of trustees, or any committee of } \\
\text { the board, but not approved for implementation. Also include any programs } \\
\text { that were returned prior to board consideration by the university } \\
\text { administration for additional development, significant revisions, or re- } \\
\text { conceptualization; regardless of whether the proposal was eventually taken } \\
\text { to the university board for approval. Count the returns once per program, } \\
\text { not multiple times the proposal was returned for revisions, unless there is a } \\
\text { total re-conceptualization that brings forward a substantially different } \\
\text { program in a different CIP Code. Do not include new majors or } \\
\text { concentrations added under an existing degree program CIP Code. } \\
\text { Source: University Submission. This table reports the program changes } \\
\text { between May 5, } 2009 \text { and May 4, } 2010 \text {. }\end{array}$ \\
\hline $\begin{array}{l}\text { Table 5B. } \\
\text { Graduate Degrees } \\
\text { Awarded }\end{array}$ & $\begin{array}{l}\text { Definition: These are degrees granted as reported for data element 01081. Due } \\
\text { to changes in IPEDS, the doctoral and first professional degree categories no } \\
\text { longer exist. Now they are classified as doctoral research and doctoral } \\
\text { professional with the doctoral professional including additional categories } \\
\text { that had not previous been included in the first professional category. The } \\
\text { universities reviewed their programs and made the classifications of their } \\
\text { programs. The professional doctoral category will include all degrees in this } \\
\text { category. Medicine, Law, and Pharmacy degrees will be reported as a sub- } \\
\text { category of professional doctoral degrees. } \\
\text { Source: SUS Student Instruction File, element \#01081 ("Degree-Level } \\
\text { Granted") }\end{array}$ \\
\hline $\begin{array}{l}\text { Table 5C. } \\
\text { Graduate and } \\
\text { Professional Degrees } \\
\text { Awarded in Areas of } \\
\text { Strategic Emphasis }\end{array}$ & $\begin{array}{l}\text { Definition: Graduate degrees as reported above by six-digit Classification of } \\
\text { Instruction Program. The areas of strategic emphasis were selected by the } \\
\text { Board of Governors staff with consultation with business and industry } \\
\text { groups and input from universities. These counts may be duplicated if a } \\
\text { student earns degrees in more than one strategic area (i.e, double-majors are } \\
\text { included). } \\
\text { Source: SUS Student Instruction File, and Board of Governors list of Areas of } \\
\text { strategic Emphasis, available at the link here. }\end{array}$ \\
\hline \multicolumn{2}{|c|}{ Table 5D. Professional Licensure Exams - Graduate Programs } \\
\hline $\begin{array}{l}\text { Law: } \\
\text { Florida Bar Exam } \\
\text { *NEW }\end{array}$ & $\begin{array}{l}\text { Definition: Average pass rate for first-time examinees on the Florida Bar Exam. } \\
\text { Cohorts are examinees who sit for both Parts A and B of the examination. } \\
\text { Data is organized by Calendar Year, which includes first-time examinees for } \\
\text { the February and July test administrations. State Benchmark data is based on } \\
\text { the subtraction of first-time examinees from non-Florida law schools from } \\
\text { the Total first-time examinees. } \\
\text { Source: Florida Board of Bar Examiners http://www.floridabarexam.org/ }\end{array}$ \\
\hline $\begin{array}{l}\text { Medicine: } \\
\text { USMLE Exams } \\
\text { *NEW }\end{array}$ & $\begin{array}{l}\text { Definition: Average pass rate for first-time examinees on the US Medical } \\
\text { Licensing Examinations (USMLE). Cohorts for the Part I exam are second- } \\
\text { year MD students. Cohorts for the Part II exams are fourth-year MD } \\
\text { students. National benchmark data is based on Jan-Dec (for Step } 1 \text { exam) } \\
\text { and July-June (for both Step } 2 \text { exams) results for first-time examinees from } \\
\text { students in US and Canadian medical schools as published in the National } \\
\text { Board of Medical Examiners Annual Report. }\end{array}$ \\
\hline
\end{tabular}

\begin{tabular}{|c|c|}
\hline & $\begin{array}{l}\text { Source: University Data Submission; Benchmark: NBME's USMLE Performance } \\
\text { Data: http://www.usmle.org/Scores_Transcripts/performance/2008.html }\end{array}$ \\
\hline $\begin{array}{l}\text { Dentistry: } \\
\text { NDBE Exams } \\
\text { *NEW }\end{array}$ & $\begin{array}{l}\text { Definition: Average pass rate for first-time examinees on the National Dental } \\
\text { Board Examination (NBDE). Cohorts for the Part I exam are second-year } \\
\text { Dental students. Cohorts for the Part II exam are fourth-year Dental } \\
\text { students. Note: The Dental Board Exam is a national standardized } \\
\text { examination not a licensure examination. Students also take the Florida } \\
\text { Licensure Examination if they wish to practice in Florida. Please note that } \\
2007 \text { was the first year the NDBE was administered after significant } \\
\text { revisions to the test. } \\
\text { Source: University of Florida. }\end{array}$ \\
\hline $\begin{array}{l}\text { Veterinary Medicine: } \\
\text { NAVLE Exam } \\
\text { "NEW }\end{array}$ & $\begin{array}{l}\text { Definition: Average pass rate for first-time examinees on the North American } \\
\text { Veterinary Licensing Examination (NAVLE) for graduates or senior } \\
\text { veterinary students taking. National benchmark data is based on Fall \& } \\
\text { Spring results for first-time examinees (criterion group) for senior students } \\
\text { in accredited veterinary schools as published by the National Board of } \\
\text { Veterinary Medical Examiners' annual NAVLE Candidate Performance Data } \\
\text { report. } \\
\text { Source: University of Florida; NBVME: http://www.nbvme.org/?id=82 }\end{array}$ \\
\hline $\begin{array}{l}\text { Pharmacy: NAPL } \\
\text { Exam } \\
\text { *NEW }\end{array}$ & $\begin{array}{l}\text { Definition: Average pass for rate first-time examinees on the North American } \\
\text { Pharmacist Licensure Examination (NAPLEX). Chorts are graduates from } \\
\text { Accreditation Council for Pharmacy Education-accredited schools and } \\
\text { colleges of pharmacy. National benchmark data is based on Jan-Dec results } \\
\text { for first-time examinees that are graduates from ACPE-accredited United } \\
\text { States schools and colleges of pharmacy as published by the National } \\
\text { Association of Boards of Pharmacy. } \\
\text { Source: National Association of Boards of Pharmacy (NABP) } \\
\text { http://www.nabp.net/programs/examination/naplex/school-pass-rate/ }\end{array}$ \\
\hline $\begin{array}{l}\text { Ed. Leadership: FELE } \\
\text { Exam } \\
\text { *SCHEDULED FOR } \\
\text { THE } 2011 \text { REPORT }\end{array}$ & $\begin{array}{l}\text { Definition: Average pass rate for first-time examinees on the Florida Education } \\
\text { Leadership Examination (FELE). } \\
\text { Source: Florida Department of Education }\end{array}$ \\
\hline \multicolumn{2}{|c|}{$\begin{array}{l}\text { Section } 6 \text { - Research and Economic Development } \\
\text { Table 6A. Research and Development }\end{array}$} \\
\hline $\begin{array}{l}\text { Federally Funded } \\
\text { Awards } \\
\text { (Thousands of Dollars) } \\
\text { "NEW }\end{array}$ & $\begin{array}{l}\text { Definition: Federally funded awards for research; excludes awards for } \\
\text { instruction, outreach, public service, or other sponsored activities; excludes } \\
\text { sub-awards institution received as a sub-recipient. Dollars in thousands. } \\
\text { Source: NSF Survey of R\&D Expenditures at Universities and Colleges. Old format: } \\
\text { Item 4, Line } 2010 \text { and 2020. New format: Question } 20 \text { (A+B). }\end{array}$ \\
\hline $\begin{array}{l}\text { Total Aw } \\
\text { (Thousan } \\
\text { *NEW }\end{array}$ & $\begin{array}{l}\text { S awards for instruction, outreach, } \\
\text {; excludes sub-awards institution } \\
\text { sands. } \\
\text { iversities and Colleges. Old format: } \\
\text {. }\end{array}$ \\
\hline $\begin{array}{l}\text { Federally Financed } \\
\text { Expenditures } \\
\text { (Thousands of Dollars) }\end{array}$ & $\begin{array}{l}\text { all research activities (including } \\
\text { lllars are in thousands. } \\
\text { iversities and Colleges, Old format: } \\
\text { A. }\end{array}$ \\
\hline
\end{tabular}

2010 Annual Report Data Definitions - Page 8 


\begin{tabular}{|c|c|}
\hline $\begin{array}{l}\text { Total Expenditures } \\
\text { (Thousands of Dollars) }\end{array}$ & $\begin{array}{l}\text { Definition: Total expenditures for all research activities (including non-science } \\
\text { and engineering activities). Dollars are in thousands. } \\
\text { Source: NSF Survey of R\&D Expenditures at Universities and Colleges. Old format: } \\
\text { Item 2A (Line 2000). New format: Question 1G. }\end{array}$ \\
\hline $\begin{array}{l}\text { Total Research and } \\
\text { Development } \\
\text { Expenditures Per Full- } \\
\text { Time, Tenured, } \\
\text { Tenure-Earning Faculty } \\
\text { Member }\end{array}$ & $\begin{array}{l}\text { Definition: Total R\&D expenditures are divided by fall, full-time } \\
\text { tenured/tenure-track faculty as reported to IPEDS. (For FGCU, the ratio will } \\
\text { be based on both tenured/tenure-track and non-tenure/track faculty.) The } \\
\text { fall faculty year used will align with the beginning of the fiscal year, so that } \\
\text { (e.g.) 2007 FY R\&D expenditures are divided by fall } 2006 \text { faculty. } \\
\text { Sources: NSF, Webcaspar database (R\&D expenditures) and IPEDS (faculty) }\end{array}$ \\
\hline $\begin{array}{l}\text { Invention Disclosures } \\
\text { Received }\end{array}$ & $\begin{array}{l}\text { Definition: Disclosures, no matter how comprehensive, that are made in the } \\
\text { fiscal year. } \\
\text { Source: AUTM Licensing Survey (or using AUTM definitions for institutions } \\
\text { that do not participate in that survey) }\end{array}$ \\
\hline $\begin{array}{l}\text { Total U.S. Patents } \\
\text { Issued }\end{array}$ & $\begin{array}{l}\text { Definition: U.S. patents issued or reissued in the fiscal year. } \\
\text { Source: AUTM Licensing Survey (or using AUTM definitions for institutions } \\
\text { that do not participate in that survey) }\end{array}$ \\
\hline $\begin{array}{l}\text { Patents Issued Per 1,000 } \\
\text { Full-Time, Tenure and } \\
\text { Tenure Earning Faculty }\end{array}$ & $\begin{array}{l}\text { Definition: Total U.S. patents issued in the fiscal year divided by the Full-time, } \\
\text { Tenure and Tenure Earning Faculty from the Fall term. } \\
\text { Sources: AUTM Licensing Survey or comparably defined data from } \\
\text { institutions (patents) and IPEDS (full-time faculty) }\end{array}$ \\
\hline $\begin{array}{l}\text { Total Number of } \\
\text { Licenses/Options } \\
\text { Executed }\end{array}$ & $\begin{array}{l}\text { Definition: Licenses/options executed in the fiscal year for all technologies. } \\
\text { Each agreement is counted separately. } \\
\text { Source: AUTM Licensing Survey (or using AUTM definitions for institutions } \\
\text { that do not participate in that survey) }\end{array}$ \\
\hline $\begin{array}{l}\text { Total Licensing Income } \\
\text { Received }\end{array}$ & $\begin{array}{l}\text { Definition: License issue fees, payments under options, annual minimums, } \\
\text { running royalties, termination payments, amount of equity received when } \\
\text { cashed-in, and software and biological material end-user license fees of } \\
\$ 1,000 \text { or more, but not research funding, patent expense reimbursement, } \\
\text { valuation of equity not cashed-in, software and biological material end-user } \\
\text { license fees of less than } \$ 1,000 \text {, or trademark licensing royalties from } \\
\text { university insignia. } \\
\text { Source: AUTM Licensing Survey (or using AUTM definitions for institutions } \\
\text { that do not participate in that survey) }\end{array}$ \\
\hline $\begin{array}{l}\text { Number of Start-Up } \\
\text { Companies } \\
{ }^{*} \text { NEW }\end{array}$ & $\begin{array}{l}\text { Definition: The number of start-up companies that were dependent upon the } \\
\text { licensing of University technology for initiation. } \\
\text { Source: AUTM Licensing Survey (or using AUTM definitions for institutions } \\
\text { that do not participate in that survey) }\end{array}$ \\
\hline \multicolumn{2}{|c|}{ Table 6B. Centers of Excellence } \\
\hline $\begin{array}{l}\text { Centers of Excellence } \\
{ }^{*} \text { REVISED }\end{array}$ & $\begin{array}{l}\text { Definition: These data only includes activities directly associated with the } \\
\text { Center. The non-Center activities for faculty who are associated with the } \\
\text { Center are not included. Collaboration effectiveness metrics only report on } \\
\text { relationships that include financial, or in-kind, support. } \\
\text { Source: Universities submit this data for the annual report. }\end{array}$ \\
\hline \multicolumn{2}{|c|}{ Table 6C. State University Research Commercialization Assistance Grants } \\
\hline $\begin{array}{l}\text { State University } \\
\text { Research } \\
\text { Commercialization } \\
\text { Assistance Grants } \\
{ }^{*} \text { REVISED }\end{array}$ & $\begin{array}{l}\text { This table summarizes the activities associated with the one-time grants } \\
\text { provided by the State University Research Commercialization Assistance } \\
\text { Grant Program as established by The 21st Century Technology, Research, } \\
\text { and Scholarship Enhancement Act (1004.226, F.S.). Note: the } 2010 \text { Annual } \\
\text { Report will only include grants awarded in 2007-08. The } 2011 \text { Annual }\end{array}$ \\
\hline
\end{tabular}

\section{1st Century World}

Class Scholars Program

${ }^{*} \mathrm{NEW}$

provided by the 21st Century World Class Scholars Program as established

y The 21st Century Technology, Research, and Scholarship Enhancement Act (1004.226, F.S.). Note: the 2010 Annual Report will only include grants awarded in 2006-07.

Source: Universities submit this data for the annual report. 
